\title{
Stem Cell Therapy in Heart Diseases - Cell Types, Mechanisms and Improvement Strategies
}

\author{
Paula Müllera,b Heiko Lemcke ${ }^{a, b}$ Robert David ${ }^{a, b}$ \\ aReference and Translation Center for Cardiac Stem Cell Therapy (RTC), Department of Cardiac Surgery, \\ Rostock University Medical Center, Rostock, ${ }^{b}$ Department Life, Light and Matter of the Interdisciplinary \\ Faculty at Rostock University, Rostock, Germany
}

\section{Key Words}

Mesenchymal stem cells • Cardiovascular diseases - Cell replacement - Cardiac regeneration - Stem cell modification

\begin{abstract}
A large number of clinical trials have shown stem cell therapy to be a promising therapeutic approach for the treatment of cardiovascular diseases. Since the first transplantation into human patients, several stem cell types have been applied in this field, including bone marrow derived stem cells, cardiac progenitors as well as embryonic stem cells and their derivatives. However, results obtained from clinical studies are inconsistent and stem cell-based improvement of heart performance and cardiac remodeling was found to be quite limited. In order to optimize stem cell efficiency, it is crucial to elucidate the underlying mechanisms mediating the beneficial effects of stem cell transplantation. Based on these mechanisms, researchers have developed different improvement strategies to boost the potency of stem cell repair and to generate the "next generation" of stem cell therapeutics. Moreover, since cardiovascular diseases are complex disorders including several disease patterns and pathologic mechanisms it may be difficult to provide a uniform therapeutic intervention for all subgroups of patients. Therefore, future strategies should aim at more personalized SC therapies in which individual disease parameters influence the selection of optimal cell type, dosage and delivery approach.

(C) 2018 The Author(s)

Published by S. Karger AG, Basel
\end{abstract}

\section{Introduction}

Accounting for more than 3.9 million deaths a year, cardiovascular diseases (CVDs) remain the most common cause of death in Europe [1]. Despite significant advancements in pharmacological and interventional treatment options, heart diseases represent an increasingly common disorder that carries a poor long-term prognosis [2, 3]. Although current approaches improve symptoms and decelerate adverse cardiac remodeling, they P. Müller and H. Lemcke contributed equally to this work. 
fail to address the underlying problem of an irreversible loss of cardiac tissue.

Innovative stem cell (SC) therapies have the potential to fundamentally alter the conventional treatment of CVDs by stimulating the regeneration of injured myocardium. In 2001, first encouraging pre-clinical study results, reporting the repair of infarcted cardiac tissue and the enhancement of ventricular function, led to the rapid translation of SC therapies within the same year [4-6]. Over the last two decades, plenty of preclinical and early clinical trials have demonstrated the safety and feasibility of numerous SC types. However, many open questions remain to be resolved and so far, no cell therapy has been unambiguously shown to be effective for the treatment of heart diseases. As a consequence, strategies have been developed in order to improve the potency of applied SCs.

In this review, we provide an historical overview about the different cell types that have been used in regenerative medicine to treat CVDs. Moreover, we highlight the potential mechanisms involved in SC-based cardiac repair. Since the efficiency of SC therapy is quite limited we further discuss promising improvement strategies to increase the outcome of SC transplantation.

\section{SC types considered for the treatment of heart disease}

It has now been almost two decades since first efforts were made in cardiac SC therapy. Nowadays, several types of SCs at different developmental stages have been evaluated with respect to their cardiovascular regeneration potential (Table 1).

\section{Skeletal myoblasts}

In the field of cardiac regeneration, skeletal myoblasts were the first cell type to be tested both in pre-clinical and clinical trials. Myoblasts are derived from satellite cells, a progenitor cell population located under the basal lamina of skeletal muscular fibers [7]. Following muscle injury, satellite cells become mobilized, proliferate, differentiate and finally fuse into new muscle fibers [8-10]. The use of skeletal myoblasts for cardiac regeneration has been motivated due to their easy accessibility from autologous muscle biopsies, rapid in vitro expansion, resistance to ischemic conditions, myogenic capacity and low risk of tumorigenicity
Table 1. Advantages and disadvantages of stem cell (SC) types used for cardiac regeneration

\begin{tabular}{|c|c|c|}
\hline Cell type & Advantages & Disadvantages \\
\hline $\begin{array}{l}\text { Skeletal } \\
\text { myoblasts }\end{array}$ & $\begin{array}{l}\text {-Easy access from autologous } \\
\text { muscle biopsies } \\
\text { - Low ethical concerns } \\
\text {-Rapid in vitro expansion } \\
\text {-Resistant to ischemic conditions } \\
\text { - Low risk of tumorigenicity }\end{array}$ & $\begin{array}{l}\text {-No transdifferentiation into functional cardiomyocytes } \\
\text {-Hazard of ventricular arrhythmias due to the lack of } \\
\text { electromechanical coupling }\end{array}$ \\
\hline HSCs/EPCs & $\begin{array}{l}\text {-Easy access from autologous } \\
\text { bone marrow or blood } \\
\text {-Low ethical concerns } \\
\text { - Proof of safety in clinical triaels } \\
\text {-Straightforward and } \\
\text { standardized isolation procedures } \\
\text { of HSCs } \\
\text {-Promotion of vasculogenesis } \\
\text {-Therapeutic secretome } \\
\text {-Low risk of tumorigenicity }\end{array}$ & $\begin{array}{l}\text { - Low cell quantity } \\
\text {-Limited differentiation potential } \\
\text {-Undefined phenotype of EPCs } \\
\text {-Heterogeneous cell population } \\
\text {-Potential encouragement of inflammatory processes } \\
\text {-Inconsistent results regarding therapeutic effects }\end{array}$ \\
\hline MSCs & $\begin{array}{l}\text {-Easy access from several tissues } \\
\text { - Low ethical concerns } \\
\text {-Transplantation of autologous } \\
\text { and allogenic cells due to low } \\
\text { immunogenicity } \\
\text {-Proof of safety in clinical trials } \\
\text {-Rapid in vitro expansion } \\
\text { - Therapeutic secretome } \\
\text {-Beneficial immunomodulative } \\
\text { properties } \\
\text {-Low risk of tumorigenicity }\end{array}$ & $\begin{array}{l}\text {-Limited cell quantity } \\
\text {-Limited differentiation potential } \\
\quad \text {-Undefined in situ phenotype } \\
\text {-Heterogeneous cell population } \\
\text {-Inconsistent results regarding therapeutic effects }\end{array}$ \\
\hline cSCs & $\begin{array}{l}\text {-Suitable for autologous } \\
\text { transplantation } \\
\text {-Proof of safety in clinical trials } \\
\text { Endogenous cardiac localization } \\
\text {-Low risk of tumorigenicity }\end{array}$ & $\begin{array}{l}\text { - Limited cell quantity } \\
\text {-Access from invasive myocardial biopsies } \\
\text {-Insufficient cell characterization } \\
\text { - Contradictory results concerning cardiovascular } \\
\text { differentiation potential }\end{array}$ \\
\hline ESCs & $\begin{array}{l}\text {-Pluripotent differentiation } \\
\text { potential } \\
\text {-Unlimited quantity } \\
\text {-Easy generation of cell lines } \\
\text {-Allows generation of off-the-shelf } \\
\text { cell products } \\
\text {-ESC-derived cardiomyocytes } \\
\text { integrate electromagnetically into } \\
\text { the host myocardium }\end{array}$ & $\begin{array}{l}\text {-Difficult to generate pure and mature cardiomyocytes in } \\
\text { large quantities } \\
\text {-Ethical concerns } \\
\text { - Risk of tumorigenicity } \\
\text {-Genomic instability } \\
\text { - Lack of availability } \\
\text {-Risk of immunologic rejection and immunosuppression } \\
\text { required }\end{array}$ \\
\hline iPSCs & $\begin{array}{l}\text {-Pluripotent differentiation } \\
\text { potential } \\
\text {-Low ethical concerns } \\
\text {-Suitable for autologous } \\
\text { transplantation } \\
\text { •Easily accessible source tissue } \\
\text {-Unlimited quantity } \\
\text {-iPSC-derived cardiomyocytes } \\
\text { integrate electromagnetically into } \\
\text { the host myocardium }\end{array}$ & $\begin{array}{l}\text {-Difficult to generate pure and mature cardiomyocytes in } \\
\text { large quantities } \\
\text {-Risk of tumorigenicity } \\
\text {-Risk of immunologic rejection due to genomic instability } \\
\text {-Low induction efficiency } \\
\text {-Lack of standardized generation procedure }\end{array}$ \\
\hline
\end{tabular}




\section{Cellular Physiology Cell Physiol Biochem 2018;48:2607-2655 \\ \begin{tabular}{ll|l} 
and Biochemistry Published onIIne: 16 August, 2018 & $\begin{array}{l}\text { (C) } 2018 \text { The Author(s). Published by S. Karger AG, Basel } \\
\text { www.karger.com/cpb }\end{array}$
\end{tabular}

[11]. A large number of research groups extensively assessed the performance of these cells for the treatment of ischemic and non-ischemic cardiomyopathies in various small and large animal models, including rodent, sheep, dog and pig [12-28]. These studies demonstrated that skeletal myoblasts are capable to differentiate into myotubes, decreased myocardial fibrosis, attenuated ventricular remodeling and improved myocardial performance. These encouraging pre-clinical results were rapidly translated into clinical trials. Thereby, several small non-randomized studies have shown an improvement in the left ventricular ejection fraction (LVEF) and New York Heart Association (NYHA) functional class, as well as an enhanced regional wall motion after the transplantation of skeletal myoblasts [29-38]. However, in most of these studies a high incidence of ventricular arrhythmias has been detected in cell treated patients $[29,30,32,33,35,38,39]$. Subsequent investigations imply that these abnormal heart rhythms most likely result from the lack of electromechanical coupling between resident cardiomyocytes and skeletal myoblast-derived myotubes due to the absence of gap junctions [40-42]. Despite these safety concerns, randomized controlled studies have been initiated which, however, failed to show consistent beneficial effects [43-46]. In the largest randomized, placebo-controlled, double-blinded MAGIC trial (NCT00102128), the intramyocardial injection of skeletal myoblasts in patients with severe ischemic heart disease did neither improve regional nor global left ventricular (LV) function after a 6 month [43] and a 6-year follow up period [47], respectively. In addition, an increased number of early postoperative arrhythmic events was recorded following cell transplantation, although a prophylactic amiodarone therapy had been initiated [43]. Overall, based on the inconsistent therapeutic effect and the risk of arrhythmias, the focus on skeletal myoblasts for the treatment of heart diseases has diminished.

\section{Bone marrow (BM)-derived SCs}

$\mathrm{BM}$ represents a highly heterogeneous tissue, harboring numerous mature and immature cell populations. The discovery that an injury causes the recruitment of BM-derived cells to the damaged area where they contribute to tissue regeneration has introduced the field of BM-derived SC therapy [48-52]. In 2001, a pioneering study demonstrated that intramyocardially injected murine BM-derived cells improved cardiac function in a murine model of myocardial infarction (MI) [4]. Likewise, early clinical trials reported beneficial effects of BM-derived cells for the treatment of heart diseases in the same year. Thereby, the rapid clinical translation of these cells was encouraged by the easy access of self-renewing BM with low ethical concerns, the relatively large numbers of autologous cells and broad clinical experiments with BM transplantation [53].

\section{BM-derived mononuclear cells (MNCs)}

BM-derived MNCs are a heterogeneous population which includes a small number of hematopoietic stem cells (HSCs), endothelial progenitor cells (EPCs) and mesenchymal stromal/stem cells (MSCs), whereas the major proportion comprises cells of the hematopoietic lineage at various maturation stages [54]. In 2001, the first patient was treated by intracoronary injection of autologous MNCs isolated from BM specimens via density gradient centrifugation 6 days after MI [5]. 1 year later, results of the first controlled study showed a significantly decreased infarct region as well as an improved regional contractility and perfusion 3 month after BM-derived MNC transplantation [55]. Since patients without cell application did not display changes in these parameters, the authors postulated that beneficial effects were associated with cell-based myocardial regeneration and neovascularization [55]. To date, the regenerative capacity of BM-derived MNCs is controversial. On the one hand, a wealth of randomized, controlled clinical trials demonstrated a significantly enhanced cardiac performance after intracoronary and intramyocardial transplantation of MNCs [5664] and on the other hand many studies failed to detect therapeutic cell effects [65-76]. Likewise, results of meta-analyses are inconsistent, either proving therapeutic effects of BMderived MNCs by demonstrating a slight enhancement of heart functions between 2 - 5\% 


\section{Cellular Physiology Cell Physiol Biochem 2018;48:2607-2655 \\ \begin{tabular}{ll|l} 
and Biochemistry Published onlIne: 16 August, 2018 & $\begin{array}{l}\text { (c) } 2018 \text { The Author(s). Published by S. Karger AG, Basel } \\
\text { www.karger.com/cpb }\end{array}$
\end{tabular} \\ Müller et al.: Cardiac Stem Cell Therapy}

and an decelerated cardiac remodeling [77-81] or refuting the beneficial impact of these cell population [82].

\section{BM-derived HSCs and EPCs}

Adult HSCs are multipotent SCs which are mainly localized in BM and give rise to all types of blood cells from the lymphoid and myeloid lineages [83]. EPCs represent a provasculogenic subpopulation of HSCs in the BM, sharing a number of cell surface markers like CD34 and CD133 [84]. In 1997, EPCs were first described by Asahara et al. [85], however, a proper and unambiguous molecular characterization of these cells is still lacking [86, 87]. In 2001, our group initiated the first phase I clinical trial injecting autologous BM-derived $\mathrm{CD}_{133^{+}} \mathrm{SCs}$ into the infarcted border zone during coronary artery bypass grafting (CABG) in 6 patients [6]. 3 months after cell transplantation, 4 patients exhibited an enhanced global LVEF and 5 patients showed an improved infarcted tissue perfusion. Moreover, it was assumed that intramyocardial transplantation of BM-derived $\mathrm{CD}_{133^{+}}$cells is safe and may induce angiogenesis. These encouraging results were confirmed in the following phase II clinical study demonstrating improved LVEF and myocardial perfusion 6 month after SC transplantation compared to the standard therapy group [88]. To date, several phase I and II clinical trials reported the safety, feasibility and beneficial effects of intramyocardially [89, 90] and intracoronary [91-95] injected BM-derived CD133+ cells for the treatment of cardiac diseases. However, long term follow-up studies failed to show an improved cardiac function in SC treated patients after several years [96, 97]. In the first reported phase II/III clinical trial (CARDIO 133, NCT00462774) the scar size and regional perfusion were significantly improved following intramyocardial transplantation of $\mathrm{CD}_{133^{+}} \mathrm{SCs}$, nevertheless, no effects on global function and clinical symptoms were detected [98]. Similar results were obtained in our randomized, placebo-controlled, double-blinded phase III clinical trial (PERFECT, NCT00950274) where a reduction in scar size and non-viable tissue as well as an improvement of segmental myocardial perfusion was observed, while no significant difference in LVEF were detected after CD133+ SC injection [99].

In addition to CD133, CD34 has been identified as a suitable single surface marker for the enrichment of human HSCs and EPCs. Early clinical trials demonstrated the safety, feasibility and potential efficacy of BM-derived $\mathrm{CD}^{3} 4^{+}$cells for the treatment of cardiac diseases [100103]. However, one of the largest randomized, controlled clinical studies failed to detect improved cardiac functions following intracoronary CD34+ SC transplantation [104].

\section{BM-derived MSCS}

MSCs are a subset of non-hematopoietic SCs that are multipotent and plastic-adherent under culture conditions [105]. Typically, these cells are characterized by their ability to differentiate into osteoblasts, adipocytes and chondrocytes under defined in vitro conditions and their expression of specific cell surface markers like CD73, CD105 and CD90, while CD34, CD45, CD14, HLA-DR are lacking [106]. Notably, MSCs are considered to be immuneprivileged and exhibit immunosuppressive properties, which enables their application in an allogenic setting [107]. A recent meta-analysis, including 58 pre-clinical studies, indicated an overall reduced infarct size of $\sim 7 \%$ as well as an improved heart function of $\sim 11 \%$ after MSC transplantation in animal models of acute myocardial infarction (AMI) and chronic ischemic cardiomyopathy (ICM) [108]. In consistence with this, Karantalis et al. demonstrated that the intramyocardial injection of MSCs in patients undergoing CABG reduced scar size and improved tissue perfusion as well as regional function predominantly at the site of injection [109]. However, the beneficial effects of MSCs on global cardiac function in a clinical setting remain uncertain. Several randomized controlled clinical trials showed a significantly improved LVEF after MSC transplantation [110-112], whereas others did not observe differences between SC treated and control groups [74, 113-117]. Furthermore, neither a recent meta-analysis of pre-clinical studies [118] nor comparative clinical studies $[119,120]$ detected significant differences of autologous versus allogeneic MSCs on cardiac function. 
Mobilized stem and progenitor cells

The migration of SCs is a constant bidirectional process including SC homing and mobilization [121]. At steady state in healthy donors, the concentration of SCs in BM is much higher than in peripheral blood (PB) [122]. However, the observation that an acute MI causes a significant mobilization of circulating stem and progenitor cells indicated that these cells play a critical role for cardiac healing processes [123-126]. To date, certain factors such as granulocyte colony-stimulating factor (G-CSF) are systemically applied to stimulate an increase of stem and progenitor cells in PB [127]. Nevertheless, meta-analyses demonstrated that G-CSF treatment after AMI did not improve cardiac regeneration [128-130]. Clinical trials using G-CSF mobilized stem and progenitor cells have led to inconsistent data. Several studies showed significant therapeutic effects after intramyocardial or intracoronary injection of PB-derived MNCs [131-134] and CD34 ${ }^{+}$[135-144], whereas others did not detect functional differences between SC-treated and control groups [72, 145, 146]. Nevertheless, recently published data suggested that low circulating stem and progenitor cell counts are associated with minor heart function improvement after MI [99] and contribute to the development and progression of heart failure (HF) [147].

\section{Adipose-derived stem and progenitor cells}

In 2001, Zuk et al. demonstrated that adipose tissue represents an abundant source of adult SCs bearing multipotent differentiation potential [148, 149]. These adiposederived stromal/stem cells (ASCs) exhibit properties similar to BM-derived MSCs including their plastic adherence and their ability to differentiate into osteoblasts, adipocytes and chondrocytes under certain in vitro conditions [150]. In addition, cultured ASCs express surface markers in common with BM-derived MSCs like CD73, CD105 and CD90, whereas CD45 is lacking [150]. However, ASCs can be distinguished from BM-derived MSCs by their expression of CD34 in early passages and the absence of CD106 [150]. The ability of these cells to significantly reduce cardiac remodeling and infarct size as well as to improve cardiac function has been demonstrated in various pre-clinical studies [151-164]. In 2012, Duckers and co-workers were the first reporting the feasibility, safety and beneficial effects, including reduced myocardial scar formation and improved perfusion, of intracoronary infused adipose tissue-derived cells in a randomized, placebo-controlled clinical trial [165]. These freshly isolated cells obtained from adipose tissue by enzymatic or non-enzymatic dissociation are also termed stroma vascular fraction (SVF) and comprise a heterogeneous mixture containing ASCs, endothelial (progenitor) cells, blood cells, pericytes and other cell types [166]. Since then, other phase I and II clinical studies confirmed the safety and usability of these cells [167-169]. However, the two largest placebo-controlled clinical trials, including 27 and 31 patients respectively, failed to detect significant changes in LV functions or volumes after the transplantation of adipose-derived cells, although an improvement in maximal oxygen consumption was observed $[167,168]$. Nevertheless, the results of larger phase III clinical trials remain to be seen.

\section{Cardiac stem and progenitor cells}

The adult heart has been traditionally considered a post-mitotic organ without significant capacity for self-renewal. However, this point of view has recently changed with the detection that the heart is capable of - albeit quite limited - cardiomyocyte turnover [170, 171]. Beltrami et al., were the first who discovered self-renewing c-Kit ${ }^{+}$cells in the adult heart, able to differentiate into cardiomyocytes, endothelial cells and smooth muscle cells and to support the regeneration of injured heart tissue [172-174]. During the past decade, several different populations of cardiac stem cells (CSCs) and cardiac progenitor cells (CPCs), such as cardiosphere-derived cells (CDCs) [175-178], stem cell antigen (Sca) $-1^{+}$cells [179- 
181], insulin gene enhancer protein (Isl)-1+ cells [182-184] and cardiac side population cells [185-187], have been found. Furthermore, various fate mapping studies indicated that resident cardiac stem and progenitor cells can contribute to adult cardiomyogenesis by direct differentiation [188-190]. Soon after the discovery of CSCs, in vivo experiments were initiated leading to promising results. A systemic analysis of 80 animal studies revealed an improvement of the LVEF by $\sim 11 \%$ after application of CSCs when compared with placebo groups [191]. Surprisingly, this positive therapeutic effect of CSCs was significantly more pronounced in small animal models compared to large animal models $(\sim 12 \%$ vs. $\sim 5 \%$ improved LVEF), while other parameters like comorbidities, cell origin and disease models did not affect the benefit of SC treatment [191]. In 2011, data from the first phase I clinical trial (SCIPIO, NCT00474461) demonstrated no mortality or CSC-related adverse events after intracoronary infusion of autologous c-Kit ${ }^{+} \mathrm{CSCs}$ in patients with ischemic cardiomyopathy [192]. The evaluation by magnetic resonance imaging (MRI) suggested an improvement of the global and regional heart function, a decrease of the infarct size and an increase of viable tissue 4 and 12 months post SC injection [193]. The benefits of CSCs were further confirmed by the CADUCEUS trial (NCT00893360) in which CDCs grown from endomyocardial biopsy tissue were delivered into patients suffering from LV dysfunction following MI [194]. Beside safety and feasibility of intracoronary SC injection, the transplantation of CDCs reduced infarct size, increased the amount of viable myocardium and improved regional contractility and regional systolic wall thickening $[194,195]$. In contrast, no difference in LV function and volume could be detected between SC-treated patients and untreated control groups. In the first randomized controlled phase II clinical trial PERSEUS (NCT01829750) the absolute changes in LV function were significantly greater in CDC-treated patients than in the control group (6.4\% vs. $1.3 \%$ ) after 3 months [196]. Compared to baseline, beneficial SC effects, including improved ventricular functions and volumes as well as reduced HF status and cardiac fibrosis, persist even 1 year after intracoronary SC injections in patient with univentricular heart disease [196].

\section{Embryonic stem cells (ESCs)}

ESCs are derived from the inner cell mass of the blastocyst and bear the capacity of self-renewal and differentiation into cell types of all 3 germ layers (endoderm, mesoderm, ectoderm) [197]. To date, many different in vitro protocols have been established to induce cardiomyogenic differentiation of ESCs, although the generation of pure and mature cardiomyocytes in large quantities of is still challenging $[198,199]$. In early animal studies it was suggested that the cardiac environment is sufficient to trigger the differentiation of injected ESCs into cardiomyocytes replacing injured host tissue [200, 201]. However, further in vivo experiments demonstrated teratoma formation after intramyocardial injection of undifferentiated ESCs [202-204]. Therefore, the focus has been placed on the development of new strategies aiming at the identification, generation and purification of ESC-derived cardiac cells. In this respect, more sophisticated pre-clinical studies showed that ESC-derived cardiomyocytes are capable to electromagnetically integrate into the host myocardium and thereby positively influence the cardiac remodeling process, diminished scar formation and improved heart function without formation of teratomas in small and large animal models [203-212]. These promising pre-clinical data have led to the initiation of the first phase I clinical trial (ESCORT, NCT02057900) in which human ESC-derived cardiac progenitors embedded into a fibrin matrix were applied to patients suffering from severe HF. For cell preparation, ESCs were first treated with bone morphogenetic protein (BMP)-2 and the fibroblast growth factor (FGF) receptor inhibitor SU-5402, afterwards cells were immunomagnetically sorted to generate a stage-specific embryonic antigen (SSEA)1 positive population which in addition strongly expresses Isl-1 [213]. In 2015, results of the first patient were published indicating no complications such as arrhythmias or tumor formation, whereas LVEF was increased by $10 \%$ and an improvement of symptoms from 
NYHA class III to I was observed [214]. Despite this positive outcome, the clinical application of ESCs and their derivatives for the treatment of CVDs is controversially discussed since the use of ESC provokes several ethical concerns [215]. Additionally, the risk of immune rejection [202, 216], genetic instability [217-219] and tumorigenic potential [197] still hampers their clinical translation.

\section{Induced pluripotent stem cells (iPSCs)}

In 2006, Takahashi and Yamanaka were the first reporting the generation of pluripotent SCs from mouse fibroblasts by retroviral introduction of 4 defined transcription factors (c-Myc, octamer-binding transcription factor (Oct)3/4, Sox2, Kruppel-like factor (Klf)4) [220]. These, so called iPSCs, exhibited certain properties similar to murine ESCs, including their differentiation capacity, morphology and SC marker expression [220]. 1 year later, human iPSCs were established by applying the same technology to human fibroblasts [221]. Nowadays, several cardiac differentiation protocols have been developed for mouse [222-224] and human [225-228] iPSCs. However, functional analyzes of iPSC-derived cardiomyocytes revealed that these cells are immature and more related to embryonic rather than to adult cardiomyocytes [229-233]. In MI animal models it was demonstrated that transplanted cardiomyocyte-like cells generated from iPSCs are able to integrate into the host tissue as well as to improve cardiac function and alleviate adverse remodeling processes [234-240]. When compared with ESCs, patient-specific iPSCs-derived cells were thought to provide significant advantages, such as the lack of ethical issues and immune response [221, 241]. However, various studies described genomic instabilities in iPSC lines resulting either from pre-existing variations in parental adult cells or from mutations occurring during the reprogramming process and culturing time (summarized in: [242]). The unexpected finding that transplanted iPSC-derived cells possess immunogenic capabilities raised additional major concerns about the safety of iPSCs [243, 244]. To overcome these issues, new protocols have been established, minimizing the potential for mutagenesis during the reprogramming process by using non-integrating gene delivery approaches [245-250] or by introducing proteins [251, 252], modified messenger ribonucleic acids (mRNAs) [253] and microRNAs (miRs) [254, 255]. Recently, also chemically induced iPSCs have been generated by applying a cocktail of small molecules [256-258]. Despite these significant improvements, human iPSC-derived cells did not reached clinical translation for the treatment of cardiovascular diseases, yet.

\section{Potential mechanisms of adult SCs in cardiovascular regeneration}

Investigating the mechanisms by which different SC types govern the regeneration of infarcted heart tissue is of utter importance for the development and improvement of novel SC therapeutics. The capacity of SCs to repair damaged tissue is mainly based on indirect/paracrine and direct mechanisms (Fig. 1). The latter includes the direct cardiac differentiation of injected SCs and the integration into the myocardium to compensate the loss of cardiomyocytes or endothelial cells [259]. However, data obtained from numerous in vitro and in vivo studies led to the conclusion that paracrine signaling is the fundamental mechanism that mediates the beneficial effects of SC therapy [260, 261].

\section{Direct mechanisms - (trans-) differentiation of SCs}

Initially,transplantedBM-derivedSCswerethoughttocontribute to thefunctional recovery of damaged myocardial tissue by electromechanically coupling with the host myocardium after acquiring a cardiomyogenic fate and by promoting neovascularization through direct differentiation into a vascular phenotype $[4,262]$. To date, the transdifferentiation capacity of adult stem and progenitor cells into cardiomyocytes within the heart is controversially 


\section{Cellular Physiology Cell Physiol Biochem 2018;48:2607-2655 and Biochemistry Published 10.159/000492704 $\begin{aligned} & \text { DO } 2018 \text { The Author(s). Published by S. Karger AG, Basel } \\ & \text { wwww.karger.com/cpb }\end{aligned}$

Fig. 1. Stem cell (SC) therapy for cardiac regeneration. Multipotent adult SCs from various tissues (bone marrow (BM), peripheral blood (PB), cardiac tissue and adipose tissue), skeletal myoblasts and pluripotent SCs (induced pluripotent SC (iPSCs), embryonic SC (ESCs)) have been applied to stimulate cardiac regeneration of the adult heart in pre-clinical and clinical studies. SCs possess the capability to differentiate into cardiomyocytes, endothelial and smoot muscle cells, supporting the regeneration process. However, numerous in vitro and in vivo data identified indirect paracrine pathways as the main mechanisms that mediate the beneficial effects of SC therapy. The release of soluble factors positively influences the remodeling of the extracellular matrix (ECM) in the injured tissue. Similarly, the formation of new blood vessels and immunmodulatory effects are stimulated by paracrine signaling of SCs. A large number of pre-clinical studies demonstrated a significant therapeutic outcome of SC treatment, including reduced fibrosis and

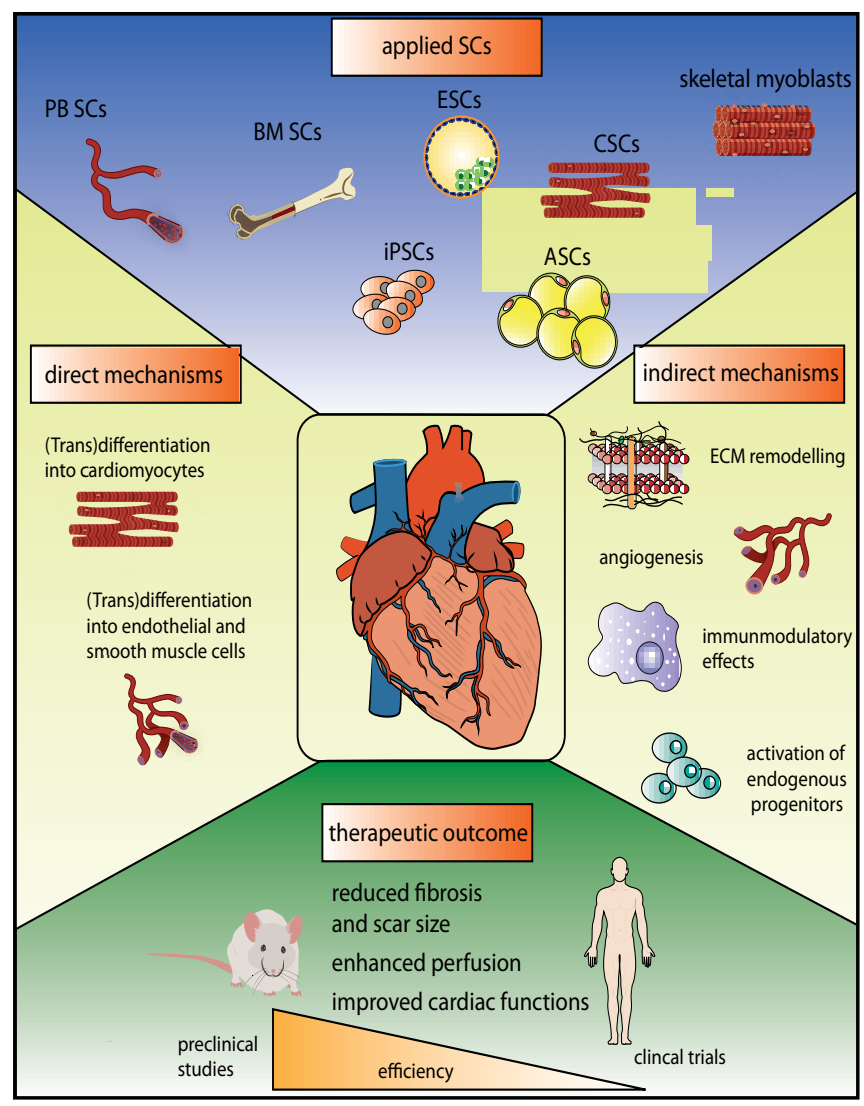
infarction size, enhanced perfusion and improved cardiac performance. In contrast, functional data obtained in clinical trials are inconsistent and did not confirm the pronounced benefits of SCs therapy observed in various animal models. CSC: cardiac SC; ASC: adipose derived stromal/stem cells.

discussed. Indeed, several studies indicated that injected BM-derived cells adopt not only an endothelial and smooth muscle cell phenotype but also transdifferentiate into functional cardiomyocytes [263-267], while others refuted this cardiogenic potential [268-271] or indicated fusion with host cardiomyocytes as the prevalent mechanism [272-274]. Likewise, both mechanisms, transdifferentiation and cell fusion, were reported to cause the conversion of PB- and adipose tissue-derived stem and progenitor cells towards a cardiomyogenic fate in vivo [275-278].

For cardiac stem and progenitor cells, similar contradictory data regarding their in vivo cardiomyogenic differentiation capacity have been published. On the one hand, several animal studies indicated that these cells give rise to newly formed cardiomyocytes by direct differentiation [172-174, 279-282]. On the other hand, it was revealed that cardiac differentiation and cell fusion with resident cardiomyocytes occur equally following transplantation of CSCs into murine MI hearts [181]. However, frequency of cardiomyogenic transformation varied significantly between different in vivo studies ranging from rare to substantial [180,187, 283, 284]. Moreover, inconclusive data were obtained regarding cell maturity, with some studies demonstrating the contractility and full maturation of newlyformed cardiomyocytes within several weeks [172, 174], while others failed to detect mature cardiomyocytes generated from transplanted c-kit ${ }^{+}$cells after years [283]. Recently, lineage tracing studies even revealed that cardiac resident c-kit ${ }^{+}$cells rarely contribute to the formation of endogenous cardiomyocyte (less than $0.03 \%$ ), but predominately represent a cardiac endothelial cell population in the developing and adult heart [285, 286].

These data reveal the potential capacity of adult stem and progenitor cells to acquire a cardiovascular phenotype in the cardiac environment. However, the (trans)differentiation of 


\section{Cellular Physiology Cell Physiol Biochem 2018;48:2607-2655 \\ \begin{tabular}{ll|l} 
and Biochemistry Published onlIne: 16 August, 2018 & $\begin{array}{l}\text { (c) } 2018 \text { The Author(s). Published by S. Karger AG, Basel } \\
\text { www.karger.com/cpb }\end{array}$
\end{tabular} \\ Müller et al.: Cardiac Stem Cell Therapy}

these cells is probably at a functionally insignificant level as this process is a highly inefficient and rare event $[180,270,285]$.

\section{Paracrine signaling}

Nowadays, it is generally accepted that secretion of soluble factors is the prevailing mechanism of SC-mediated heart regeneration. Paracrine signaling enables SCs to positively influence the surrounding cardiovascular tissue by activation of several signaling pathways, independent on the establishment of functional cell-cell contacts with the host tissue [287]. Biologically active molecules like transforming growth factor (TGF)- $\beta$, vascular endothelial growth factor (VEGF), stromal cell-derived factor (SDF)-1 and epidermal growth factor (EGF) can be secreted by transplanted stem and progenitor cells into the intestinal space or bloodstream $[288,289]$. Thus, the release of such cytokines or extracellular vesicles is a systemic event that promotes various regenerative processes, e.g. neovascularization, reduced apoptosis of endogenous cardiomyocytes, activation of tissue intrinsic progenitor cells or recruitment of cells beneficial for tissue repair [260, 287, 290]. Beside the donor's health status, chronological age significantly influences the characteristics of the SC's secretome and thereby affects their potential to promote myocardial recovery [291-293].

\section{Neovascularization}

The formation of new blood vessels is an important part of healing processes as it enables re-supply of the damaged tissue with nutrients and oxygen. The secretome of SCs has been shown to trigger neovascularization in infarcted hearts [294, 295]. Following transplantation into a MI mouse model, human CDCs were found to release pro-angiogenic factors, including VEGF, HGF and insulin-like growth factor (IGF)-1 [175]. The authors observed a $20 \%$ enhanced neovascularization after SC injection that was attributed predominantly to paracrine signaling [175]. A recently published study further confirmed the stimulating influence of CDCs on angiogenesis in mice and identified endoglin (CD105), a co-receptor for TGF- $\beta$, as an important mediator of this paracrine-stimulated neovascularization [296]. Interestingly, Cheng et al. indicated that CDCs from advanced HF patients exhibited a higher paracrine expression of SDF-1 than CDCs from healthy and recently infarcted hearts [291]. As a result, transplantation of these HF CDS into infarcted mice hearts increased the proliferation rate of endogenous endothelial cells by $\sim 30 \%$ in comparison to control CDCs [291]. Similarly, rat c-kit ${ }^{+}$CSCs significantly improved angiogenesis post MI in a paracrine manner by the secretion of VEGF [297].

Likewise, MSCs from different sources are capable to release pro-angiogenic factors contributing to the formation of new blood vessels [287, 298]. ASCs were shown to secrete VEGF, HGF and IGF-1 in vitro and increased the capillary density in the infarct border zone by $\sim 28 \%$ when applied to rats [152]. Since direct endothelial differentiation of injected ASCs was very low $(<1 \%)$, the authors concluded that the improved neovascularization was mainly stimulated by the paracrine release of cytokines [152]. In addition, BM-derived MSCs were demonstrated to express and release cytokines that increase capillary density [299]. The therapeutic activity of the MSC secretome was further proven by Timmers et al., who intravenously injected conditioned medium of human MSCs into MI pigs [300]. After 3 weeks, animals treated with MSC conditioned media showed a significantly higher number of capillaries in the border area [300]. To unravel the underlying molecular mechanisms, overexpressing studies with MSCs were performed, indicating that GATA-4 and Akt/ extracellular signal-regulated kinase (ERK) signaling are involved in the paracrine mediated stimulation of angiogenesis [287, 301]. Pre-clinical studies applying HSCs and EPCs showed a significantly enhancement of capillary density and an increase of neovascularization in the infarct scar after MI [140, 276, 302, 303]. These beneficial cell-based effects were further confirmed in phase III clinical studies reporting improved segmental myocardial perfusion as detected by cardiac MRI $[98,99]$. Mechanistically, HSCs and EPCs were shown to directly integrate into the forming neovasculature as well as secrete pro-angiogenic factors, such as VEGF, basic FGF (bFGF), IGF-1, hepatocyte growth factor (HGF) and SDF-1 $\alpha$ [84, 304]. 


\section{Cellular Physiology Cell Physiol Biochem 2018;48:2607-2655 \begin{tabular}{ll|l} 
and Biochemistry Publisned onIIne: 16 August, 2018 & $\begin{array}{l}\text { (c) } 2018 \text { The Author(s). Published by S. Karger AG, Basel } \\
\text { www.karger.com/cpb }\end{array}$ \\
\hline
\end{tabular}

\section{Immunomodulation}

Immunomodulatory properties have been well described for MSCs, which are capable to interact with cells of the innate and adaptive immune system [305]. Therefore, MSCs can influence inflammatory processes after AMI and in HF [306].

In particular the interaction of T cells and MSCs has been investigated intensively. Several studies demonstrated that MSCs are capable to suppress the proliferation and activation and induce the apoptosis of T cells by both, a direct cell-cell contact-dependent mechanism and by releasing soluble factors like indoleamine 2, 3-dioxygenase (IDO), nitric oxide (NO), HGF, TGF- $\beta$, human leukocyte antigen class I molecule G5 (HLA-G5) and programmed cell death protein 1 (PD-1) [307-314]. Moreover, it was shown that MSCs can stimulate the generation of regulatory T (Treg) cells by their secretion of TGF- $\beta$ and interleukin (IL)-10 $[305,309,315,316]$. Treg cells promote the switch from an initial inflammatory phase to an inflammation resolution phase after AMI and thereby contribute to an improved wound healing $[317,318]$. However, it was demonstrated that immunomodulatory properties of MSCs are significantly influenced by their environment [319, 320]. In response to high levels of pro-inflammatory cytokines such as interferon (IFN)- $\gamma$ and tumor necrosis factor (TNF- $\alpha$ ), MSC adopt an immune-suppressive phenotype [305]. As a result, MSCs secrete high levels of $\mathrm{T}$ cell suppressing factors and simultaneously express adhesion molecules and chemokines, including CXC chemokine receptor (CXCR) 3 and C-C chemokine receptor type 5 (CCR5) ligands, intercellular adhesion molecule 1 (ICAM-1) and vascular cell adhesion molecule (VCAM-1), to attract T cells into their close proximity [305, 321]. Reversely, in the absence of an inflammatory environment, MSCs still produce T cell recruiting molecules but secrete only low levels of immune-suppressive factors resulting in an enhanced T cell response [319, $321,322]$.

Furthermore, SCs can influence the polarization of macrophages. Initial studies reported that lymphocyte antigen 6 complex, locus C (Ly6C) high expressing monocytes/ macrophages secreting large amounts of pro-inflammatory mediators such as IL-6 and TNF- $\alpha$ are the predominant population at the early inflammatory phase after MI, whereas Ly6Clow monocytes/macrophages producing anti-inflammatory cytokines and growth factors including VEGF and TGF- $ß$ are recruited in later stages [323]. Recently, co-culture experiments as well as in vivo studies demonstrated that MSCs and CDC are able to facilitate the shift of macrophages from an pro-inflammatory towards an anti-inflammatory phenotype which in turn can accelerate wound healing processes [324-331].

Beside the regulation of T cells and macrophages, MSCs were shown to suppress several other cells involved in the immune response including B cells [328, 332, 333], natural killer (NK) cells [334, 335], dendritic cells [336-338] and mast cells [339-341]. Conflicting results were obtained for the interaction of MSCs and neutrophils. While several studies reported that MSCs prevent apoptosis and enhance the recruitment of neutrophils [342-345], others indicated MSC-mediated limited activity and attraction of neutrophils [346, 347]. Recently, Luger et al. demonstrated that intravenous application of human BM-derived MSCs significantly reduced the number of NK cells and neutrophils by $25-50 \%$ in hearts 7 days after MI which was associated with a reduced adverse remodeling especially in mice with large infarcts [348].

In comparative analyses, ASCs were shown to secrete higher levels of immunomodulatory cytokines like IL-6, IL-8 and TGF- $\beta$ in vitro and inhibit the differentiation of dendritic cells more efficiently than BM-derived MSCs [349, 350]. In contrast, only BM-derived MSCs reduced the cytotoxic activity of NK cell, while both, ASCs and BM-derived MSCs, decreased NK cell proliferation in a similar manner [351,352]. However, data of other SC types are very limited and additional in vitro and in vivo studies are required to elucidate the extent of their immunomodulatory and anti-inflammatory activity. 


\section{Cellular Physiology Cell Physiol Biochem 2018;48:2607-2655 \begin{tabular}{ll|l} 
and Biochemistry Publisned onlIne: 16 August, 2018 & $\begin{array}{l}\text { (c) } 2018 \text { The Author(s). Published by S. Karger AG, Basel } \\
\text { www.karger.com/cpb }\end{array}$
\end{tabular}

Recruitment of endogenous stem und progenitor cells and activation of cardiomyocyte proliferation

SC-based therapy has the potential to activate endogenous regenerative processes, including the recruitment of resident stem and progenitor cells and the stimulation of cardiomyocyte proliferation. 2 days after injection of CDCs into infarcted mice hearts, Chimenti et al. observed a co-localization of endogenous c-kit ${ }^{+}$CSCs with transplanted cells [175]. In 2011, it was demonstrated that intramyocardially injected BM-derived c-kit ${ }^{+}$cells stimulate endogenous cardiogenic progenitors without evidence for transdifferentiation or fusion of cells [353]. This was further confirmed in several other studies showing the increase of c-kit ${ }^{+}$ CSC within the heart tissue after MSC transplantation [354, 355]. Recently, the injection of $\mathrm{BM}$-derived MNC conditioned media alone was found to significantly increase the number of circulating Sca- $1^{+}$and c-kit ${ }^{+}$cells and favors the infiltration of beneficial endogenous BMderived cells, indicating paracrine signaling as the prevailing mechanism of resident cell recruitment [356]. Furthermore, SC therapy promoted the activation of epicardium-derived cells and their differentiation into endothelial cells, smooth muscle cells and cardiomyocytes [355].

In addition to the induction of endogenous stem and progenitor cells, SC delivery can stimulate cardiomyocytes to re-enter the cell cycle. The amount of proliferating cardiomyocytes and endothelial cells was significantly elevated after MSC transplantation [354]. As these proliferating cells failed to co-express the active fragment of the Notch 1 receptor N1ICD, the authors concluded that proliferating cells did not arise from endogenous CSCs [354, 357]. An augmented proliferation rate of resident cardiomyocytes was also found in MI hearts of mice treated with trophoblast-derived SCs [358]. Quantitative analysis of immunostained heart sections demonstrated a 2-fold higher cardiomyocyte turnover in mice undergone SC therapy [358]. Interestingly, it was found that the cell cycle reentry of cardiomyocytes can also be triggered by cell fusion with hematopoietic and mesenchymal stem and progenitor cells, which highlights the potency of SC therapy for the activation and stimulation of endogenous cardiac repair [359, 360].

\section{Cardiac remodeling}

Cardiac remodeling is a complex process involving several molecular, cellular and interstitial changes which result in alterations of cardiac structure and function, such as adverse cardiomyocyte organization and altered extracellular matrix (ECM) homeostasis [361]. A large number of studies have given evidence that SC therapy positively influences the cardiac remodeling process after ischemic injury. The injection of c-kit ${ }^{+}$CPCs was reported to significantly reduce collagen deposition in the peri-infarcted myocardium, to increase the thickness of the infarcted LV wall and to attenuate LV hypertrophy in small animal models $[283,362,363]$. Interestingly, the observed effects were even more pronounced when the cells were delivered via multiple injections [363]. Similar beneficial alterations of adverse cardiac remodeling in rats were detected following intramyocardial delivery of MSCs. Quantitative analyses revealed a markedly higher thickness of the infarcted LV anterior wall $(0.86 \mathrm{~mm}$ vs. $0.43 \mathrm{~mm})$ as well as a significant lower extent of fibrosis $(24.5 \%$ vs. $39.1 \%)$ in MSC-treated hearts compared to control hearts [364]. Likewise, several in vivo studies emphasized the therapeutic effects of SCs on the re-organization of infarcted heart tissue [282, 365-369]. Importantly, the potential of SCs to act on ECM deposition and to attenuate myocardial fibrosis was confirmed in human patients. In the PERSEUS clinical phase II trial (NCT01829750), intracoronary infusion of autologous CDCs was associated with a significant reduction of scar size, mass and volume 3 months after SC treatment [196]. Similarly, MSC treatment was found to significantly decrease endocardial length, LV sphericity index and scar thickness in patients suffering from ischemic cardiomyopathy $[109,119]$.

However, the mechanism by which SCs modulate the organization of the ECM is still under investigations. It has been suggested that matrix metalloproteinases (MMPs) might play a prominent role in reducing scar size upon SC transplantation. Administration of 
MSCs in fibrotic liver or uterine tissue was associated with lower collagen deposition and significantly increased levels of MMP-9 [370, 371]. Rising levels of MMPs in tissue were also described in SC-mediated cardiac repair. In 2008, Rota et al. demonstrated a 10-fold higher MMP-9 activity and a significant enhanced presence of MMP-2 and MMP-14 in CPC-treated hearts than in control hearts [282]. Moreover, it was shown that the inhibition of MMPs by GM6001 counteract beneficial effects of CSC injections after MI [372]. Likewise, an enhanced MMP expression in cardiac tissue has been demonstrated for MSCs in rat models [373]. Nevertheless, it remains elusive whether the increased levels of MMPs are based on active SC secretion or generated by host cells stimulated by applied SCs. The former mechanism is supported by in vitro data, showing that SCs from different sources possess the capacity to release MMPs at high levels [374-376]. However, Mias et al. indicated that MSCs modulate the phenotype of cardiac fibroblasts in vitro and promoted the secretion of MMPs [364].

In addition, suppression of the TNF-signaling is an important paracrine effect by which SCs influence cardiac remodeling processes. The administration of MSCs into a murine model of inflammatory dilative cardiomyopathy inhibited the TNF/NFKB pathway in the myocardium by the release of soluble TNF receptor 1 which in turn led to $\sim 50 \%$ reduced collagen deposition [377]. Similarly, Lee et al. demonstrated that the MSC-mediated secretion of the anti-inflammatory factor TNF- $\alpha$-induced protein 6 was associated with a significant decline of the infarction size [378]. Surprisingly, this anti-inflammatory impact on cardiac remodeling was also stimulated by MSCs trapped in the lung following intravenous injection [378].

\section{Improvement strategies of SC-based therapies}

Numerous pre-clinical studies have shown significant improvement in LVEF ranging from $7-11 \%$ after SC treatment [118, 191, 379, 380]. Moreover, a growing number of phase I and II clinical trials have proven the feasibility and safety of SC application [381]. However, data from human studies addressing functional improvement are inconsistent. Several meta-analyses and systemic reviews reported a slight but significant improvement of heart function between $2-4 \%$ [81, 382-391], while the first study including individual data of patients refuted beneficial SC effects [392]. Interestingly, it was revealed that many trial reports of SC-based therapies contain functional discrepancies and that trials with lower discrepancies tend do find smaller enhancements in LVEV [393].

This limited outcome of SC-based clinical trials requires the development and improvement of novel strategies to significantly enhance the efficiency of SCs for cardiac repair. Basically, 2 major concepts are available to generate the "next generation" of SC therapeutics: i) non genetic modification and ii) genetic engineering approaches. Using these techniques, numerous SC properties can be addressed, including homing, engraftment, survival, paracrine activity, angiogenic potential or differentiation capacity (Fig. 2). Moreover, the development of personalized treatment strategies could help to classify patients' cohorts into responders vs. non-responders, thus allowing highly specific SC-based therapy depending on individual physiological and pathological criteria.

\section{Non-genetic SC modifications}

Pharmacological pre-conditioning. Pharmacological pre-conditioning represents a convenient and cost effective technique to stimulate the regenerative activity of SCs. As these cells exert their therapeutic effects on damaged tissue mainly by paracrine signaling, drug pre-treatment was applied to promote their secretion activity [394]. For example, incubation with oxytocin increased the release of cytokines in rat MSCs, including bFGF, CXCR4 and EGF [395]. As a result, these pre-conditioned MSCs were found to enhance the survival of cocultured cardiomyocytes by $\sim 50 \%$. Further, in vitro studies described drug pre-conditioning for CDCs or human c-kit ${ }^{+}$CSCs. Inhibitors for prolyl-4-hydroxylase or cobalt protoporphyrin, an inducer of heme oxygenase 1, led to improved cell survival, increased release of cytokines 


\section{Cellular Physiology Cell Physiol Biochem 2018;48:2607-2655 and Biochemistry \begin{tabular}{l|l} 
DOI: 10.1159/000492704 & (c) 2018 The Author(s). Published by S. Karger AG, Basel \\
www.karger.com/cpb
\end{tabular}

and a higher proliferation capacity [396, 397]. The potency of pharmacological pretreatments was also confirmed in animal models of MI. Trimetazidine, an anti-ischemic drug, was applied to MSCs before transplantation into $\mathrm{MI}$ rat hearts, leading to a moderate improvement of cardiac performance and reduced fibrosis by $10 \%$ when compared to untreated cells [398]. Ex vivo pre-treatment of MSCs with the pineal hormone melatonin induced a 7-fold increase in the number of viable MSCs after intramyocardial injection resulting in an improved LVEF and a higher LV wall thickness after 2 month [364]. ASC preconditioning with sildenafil, a phosphodiesterase-5 (PDE5) inhibitor, enhanced cardiac function, reduced fibrosis, increased vascular density and stimulated the release of VEGF and bFGF when compared with non-pre-conditioned ASCs in a MI mouse model [399]. Similarly, injection of diazoxidestimulated EPCs provoked in a $50 \%$ decreased collagen deposition in rats, which was accompanied by improved ejection fraction (EF) parameters [400]. The authors also detected a 3-fold enhancement of cell engraftment and a positive effect

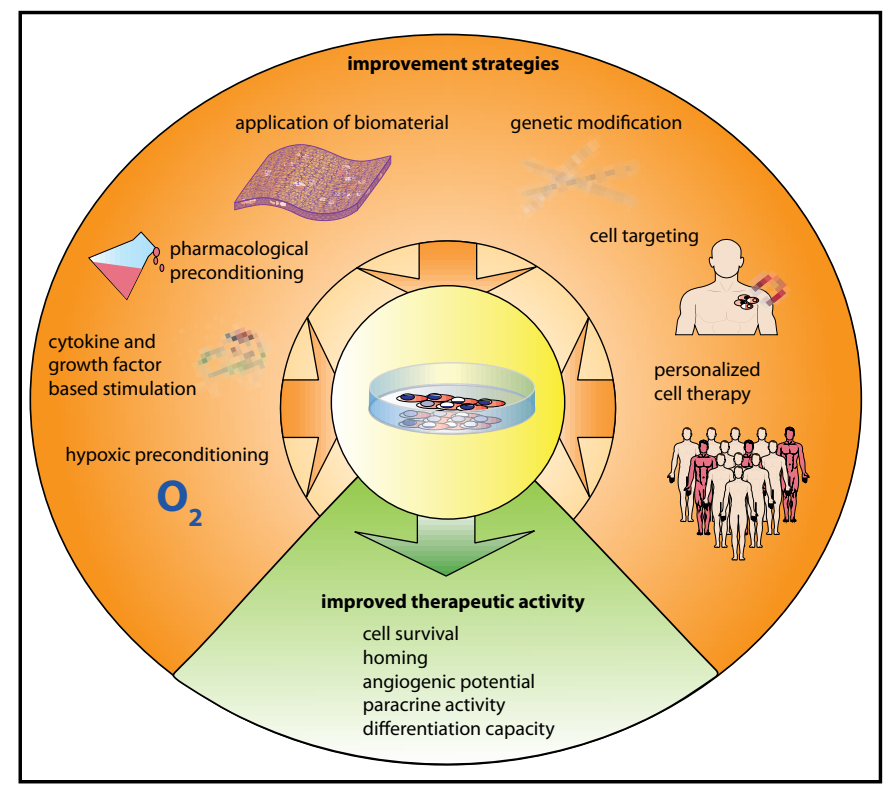

Fig. 2. Strategies for improving stem cell (SC) efficiency in the treatment of cardiovascular diseases. Genetic modifications are based on alterations of the cellular genome (genome editing, DNA) or on posttranscriptional gene regulation (miRNA, siRNA). Nongenetic strategies comprise pre-conditioning with environmental factors (elevated temperature, oxygen pressure), pharmacological agents and cytokines/growth factors. Moreover, the application of biomaterials, such as cell patches or biodegradable scaffolds, greatly enhance therapeutic effects of transplanted SCs. Cell targeting represents another strategy to augment SC efficiency, e.g. by labelling cells with magnetic particles. In addition to modifying transplanted SCs, proper patient selection is another novel approach to optimize SC therapy. This concept of personalized cell therapy relies on targeted therapeutic treatments, including the specific pathological characteristics of patients undergoing SC injection. These applied strategies improve cell survival and homing upon transplantation into the injured heart. Likewise, cardiovascular differentiation and stimulated angiogenic - and paracrine activity are common targets for SC improvement. on blood vessel formation [400].

Moreover, drug-mediated activation or inhibition of pathways can modify SC physiology relevant for cardiac regeneration. Selective activation of Rap-1 dependent signaling improves the survival and adhesion capacity of MSCs [401]. Quantitative analysis of cardiac repair revealed that these drug-treated MSCs reduced the fibrotic area by $40 \%$ and significantly improved EF and endsystolic value [401]. Likewise, stimulation of the cannabinoid receptor type 2 of ASCs before injection was found to restore cardiac function and counteract adverse tissue remodeling in mice [402]. The observed enhanced regenerative ability of SCs was suggested to be based on an increased paracrine activity and resistance to oxidative stress [402].

In addition, pharmacological compounds have been applied to promote cardiac programming of cells by interfering with important developmentally relevant pathways $[403,404]$. For instance, Protze et al. developed a transgene-independent method for the generation of pacemaker-like cells from human pluripotent SCs by applying several small 


\section{Cellular Physiology Cell Physiol Biochem 2018;48:2607-2655 \\ \begin{tabular}{ll|l} 
and Biochemistry Published onlIne: 16 August, 2018 & $\begin{array}{l}\text { (c) } 2018 \text { The Author(s). Published by S. Karger AG, Basel } \\
\text { www.karger.com/cpb }\end{array}$ \\
\hline
\end{tabular} \\ Müller et al.: Cardiac Stem Cell Therapy}

molecules, like the FGF signaling inhibitor PD-173074 and the activing/nodal/TGF- $\beta$ signaling inhibitor SB431542, for stage-specific manipulation of signaling pathways [405]. Furthermore, several other compounds were identified to boost cardiac programming of pluripotent SC, such as the Wnt signaling activator CHIR-9902, the Rho kinase inhibitor Y-27632 as well as the Wnt signaling inhibitors IWR1 IWP2 and IWP4 [406-409].

Cytokine and growth factor-based pre-conditioning. In addition to pharmacological agents, growth factors and cytokines can be utilized to modify SC activity prior administration to damaged hearts. As reported by Pasha and co-workers, pre-incubation of MSCs with SDF1 induced a profound increase of their homing ability and pro-angiogenetic properties [410]. The assessment of cardiac function and LV remodeling showed that the EF was improved by $75 \%$ and $50 \%$ less fibrotic tissue was detected within the infarct region in the SDF-1-treated MSC group [410]. Likewise, pre-treatment of BM-derived Sca-1+ $1^{+}$SCs with IGF-1 improves cell survival and engraftment in the myocardium, leading to increased blood vessel density, reduced infarction size and improved LVEF in an AMI model [411]. Enhancement of the therapeutic activity of MSCs was also achieved by pre-conditioning with TGF- $\alpha$. This positive impact on the regenerative abilities of MSCs was assumed to rely on upregulation of VEGF in stimulated MSCs [412]. Additionally, cytokines and growth factors are involved in cell fate determination and thus can be used to induce lineage-specification of SCs to generate cardiopoietic progenitors prior cell transplantation - a concept that has been proven to be beneficial in animal models $[413,414]$. In the clinical trial C-CURE (NCT00810238), MSCs were exposed to a cardiogenic cocktail (TGF- $\beta$, FGF-2, BMP-4, cardiotrophin, $\alpha$-thrombin) triggering the differentiation towards cardiac lineage [415]. Injection of these primed MSCs was shown to be safe for the treatment of chronic HF [415]. Moreover, 21 patients receiving lineage-specified SCs demonstrated improved LVEF and 6-min walk distance when compared to 15 patients receiving standard of care alone [415]. However, in the larger phase III clinical trial CHART-1 (NCT01768702) no difference was found in primary efficacy endpoints between cardiopoietic cell treatment and control group [416] albeit post hoc analysis revealed an cell-mediated reverse remodeling at 1 year follow-up [417].

Pre-conditioning with environmental factors. Numerous studies have proven that preconditioning at low oxygen levels can stimulate intrinsic cell defense mechanisms, leading to improved cell survival and positive effects on SC efficiency [394, 418, 419]. For example, CDC sheets subjected to hypoxic conditions markedly increase angiogenesis by $25 \%$ in the infarction border zone and significantly reduce collagen deposition in mice [420]. Similarly, hypoxic pre-conditioning of different SC types resulted in a higher therapeutic activity, including improved SC engraftment, migration to infarcted tissue and heart function [421426]. This enhancement of SC potency induced by lower oxygen concentration mainly relies on the up-regulation of pro-survival and pro-angiogenic factors, such as hypoxia-inducible factor (HIF)-1, angiopoietin (Ang)-1, VEGF, erythropoietin EPO)) as well as in increased CXCR-4 expression [422, 425, 426].

In addition, heat shock pre-treatment was shown to significantly improve the survival of BM-derived Sca- $1^{+}$SCs in vitro and in vivo which was mainly mediated by the heat shock protein (HSP) 70 [427]. Moreover, heat shock pre-treated cells improved global heart function after MI and efficiently reduced cardiomyocyte apoptosis likely by the secretion of heat shock factor (HSF) 1-enriched exosomes [427]. Similarly, short-time exposure of MSCs to elevated temperatures induced the expression of HSPs and decreased apoptotic rates $[428,429]$.

Application of biomaterials. Biomaterials are 3-dimensional polymeric scaffolds that have been engineered to protect cells against harsh environments and to prevent substantial cell loss after transplantation. The usage of injectable scaffolds forming a temporary ECM such as fibrin [430-432], matrigel [433], chitosan [434] and synthetic hydrogels [435, 436] improved $\mathrm{SC}$ engraftment and survival and led to an increase of cardiac performance. Biocompatible 
cell patches represent another approach to successfully improve the therapeutic outcome of SC transplantation and to avoid the shortcoming of needle injection. In numerous studies collagen and fibrin patches seeded with SCs were applied to the injured heart resulting in beneficial effects on heart function [160, 437-440]. Currently, the feasibility of fibrin patch generation embedding cardiac-committed progenitors and its efficacy on cardiac regeneration are investigated in the phase I clinical trial ESCORT (NCT02057900). Recently, Ichihara et al. demonstrated that epicardial coating with MSCs incorporated in an selfassembling peptide hydrogel significantly enhanced global cardiac function and decreased ventricular dilatation compared to intramyocardially injected MSCs in rat models of AMI and ischemic cardiomyopathy [441]. Moreover, these authors indicated a significant greater survival of donor cells (50\% vs. $20 \%$ after 3 days) and detected an upregulation of repairrelated genes including HIF-1 $\alpha$, IL-10, IGF-1 and SDF-1 in the myocardium [441]. Similar regenerative effects were obtained for epicardial delivery of 3-layerd ASC sheets produced by culturing cells on temperature-sensitive dishes [442]. Gaetani et al. reported that epicardial application of CPCs in a 3D-printed gelatin/hyaluronic acid patch supported the long-term cell engraftment, significantly reduced adverse remodeling and improved cardiac function [443]. At the same time, biomaterials can serve as carriers containing functional molecules that boost the regenrative capacity of SCs such as VEGF, bFGF, HGF, IGF-1 and TGF- $\beta$ [444448].

In addition to the generation of cell sheets and patches, biomaterials are used for the construction of complex, biomimetic 3-dimensional tissue structures or organoids, a process termed cardiac tissue engineering $[449,450]$. For in vitro generation of functional heart tissue, various cell types are required. Therefore, pluripotent SCs are the preferred SC type for the generation of multicellular tissue structures [451,452]. Nakatana et al. have recently engineered a large tissue construct consisting of cardiomyocytes, endothelial cells and vascular cells which were derived from human iPSCs [453]. Likewise, human ESCs and iPSCs have been utilized for the development of 3-dimesional microtissues formed by SC-derived cardiovascular cells $[454,455]$. In order to mimick human sized organs, specialized scaffolds are needed that provide characteristics similar to the cardiac ECM, match the strength of native myocardium and allow re-population with cardiac cells. Yet, different scaffolds are under investigation including poly-L-lactic acid (PLLA) and poly(lactic-co-glycolic acid) (PLGA) as well as natural polymers like collagen and alginate [456]. Although designing whole human hearts for transplantation still remains a long way off, there are various immidiate applications for engineered 3-dimensional cardiac tissues. In particular, they can be used for pharmaceutical drug testing and screening or as a model system to better understand the processes regulating cardiac development [451, 457, 458]. Moreover, the possibility to generate individual iPSC lines promotes the establishment of patient-specific disease models to recapitulate the underlying pathophysiological mechanisms.

Targeting of SCs. The success of SC therapy correleates with the number of cells retained at the site of injection [459]. Since the heart is a higly perfused organ, $90-99 \%$ of transplanted cells are typically lost within the first 1 to 2 hours [460-464]. Magnetic cell targeting techniques facilitate guidance of transplanted cells to the site of interest and improve cell retention [465]. For example, magnetic targeting of CDCs led to a 4-fold increase of cell engraftment after injection into ischemic rat hearts [466]. Likewise, labeling of MSCs with superparamagnetic oxide nanoparticles profoundly increased cardiac cell retention by 3 -fold using magnetic field and enhanced cardiac performance and capillary density [467]. Further in vivo and in vitro data confirmed the benefits of magnetic targeting for other SC types [468-471]. At the same time, the application of magnetic nanoparticles offers the possibility to track cells by MRI [472-475]. However, care must be taken when interpreting these MRI data. In long-term tracking studies it was demonstrated that MRI signals originate not only from labelled SCs but also from magnetic particles engulfed by macrophages and from extracellular particles [476, 477]. 
Recently, ASCs were efficiently directed to the infarct area in the heart by coating cells with microbubbles which were in turn conjugated to an antibody against ICAM-1 [478]. These so called "StemBells" lead to an improved cardiac function compared to untreated ASCs [478].

Synthetic SCs. In 2017, Cheng and co-workers published the establishment of synthetic microparticles mimicking the paracrine and biointerfacing activities of cardiospherederived CSCs and MSCs [479, 480]. These "synthetic SCs" were generated by encapsulating the secretome of SCs in biodegradable PLGA. To further improve therapeutic interaction with the host tissue, microparticles were coated with membrane fragments derived from SCs. The intramyocardial injection of these synthetic SCs into infarcted mice hearts was shown to reduce infarct size, increase wall thickness and activate endogenous repair mechanisms including recruitment of c-Kit ${ }^{+}$cells and induction of angiogenesis. Importantly, the clinical application of synthetic SCs may allow to overcome several limitations linked to SC therapy such as storage stability and tumorigenicity.

\section{Genetic SC modifications}

Genetic modification represents another powerful technique to boost SC efficiency. Compared to non-genetic based pre-conditioning genetic engineering is usually applied to induce prolonged effects on SC activity. In general, three main strategies of genetic modification are utilized, including protein overexpression after deoxyribonucleic acid (DNA) or mRNA delivery, gene editing (transcription activator-like effector nucleases (TALENs), clustered regularly interspaced short palindromic repeats (CRISPR)-Cas nucleases) as well as gene silencing (short interfering RNA (siRNA), miR) [481-484].

Using DNA-based modifications, overexpression of therapeutic factors can be induced, which promotes the regeneration process of MI-damaged tissue by paracrine signaling, including VEGF, SDF-1, FGF and IGF [485]. Explant-derived human CSCs were transduced with a lentivirus construct leading to overexpression and increased secretion of SDF$1 \alpha$ [486]. Mice treated with these modified SCs demonstrated a significant higher EF and reduced scar burden compared to unmodified control cells [486]. Interestingly, these cells were further shown to induce a 2-fold increase of proliferating cardiomyocytes and promote the recruitment of BM-derived cells which were frequently found embedded in vascular structures [486]. In another in vivo study, IGF-1 overexpression was utilized to beneficially influence the paracrine signature of human CSCs [487]. Cardiac function was slightly improved when IGF-1 modified SCs were applied [487]. Moreover, apoptotic events in the infarcted myocardium were less frequent, while myocardial regeneration was significantly enhanced [487]. Likewise, IGF-1 overexpression in ASCs improved the EF 6 weeks after cell transplantation into rats suffering from MI [488]. Zhao and colleagues induced overexpression of HGF in MSCs following administration into a mouse model of MI [489]. In addition to increased survival of modified MSCs probably induced by increased B cell lymphoma (Bcl)-2 and reduced Bax and caspase-3 levels [490], the authors detected an enhancement of angiogenesis, LVEF and proliferation capacity of resident cardiomyocytes upon SC treatment [489]. Moreover, overexpression of anti-apoptotic factors like Bcl-xL and Bcl-2 was found to positively influence the viability and therapeutic efficiency of applied SCs [491, 492]. Likewise, overexpression of Akt and integrin-linked kinase (ILK) promoted SC survival in the ischemic myocardium and increased regenerative SC properties [493497]. Enhanced survival of MSCs was found after co-overexpression of Akt and Ang-1 [498]. As a result the number of blood vessels in the peri-infarct and infarct areas increased and global cardiac function was improved [498]. The therapeutic outcome of SC therapy was also improved via modifications of SC attachment to the ECM via lentiviral mediated overexpression of integrin $\beta 1$ [499]. Moreover, genetic modifications have been extensively used for (re)programming of pluripotent ESCs and iPSCs and multipotent adult SCs into cardiovascular cell types, suitable for cell therapeutic application (summarized in: [404]).

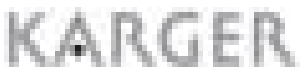




\section{Cellular Physiology Cell Physiol Biochem 2018;48:2607-2655 \\ \begin{tabular}{ll|l} 
and Biochemistry Published onIIne: 16 August, 2018 & $\begin{array}{l}\text { (C) } 2018 \text { The Author(s). Published by S. Karger AG, Basel } \\
\text { www.karger.com/cpb }\end{array}$
\end{tabular}

The stable integration of DNA into the genome of modified SCs can provoke undesired activation of oncogenic genes, which may limit their use in regenerative medicine. To reduce the risk of mutagenesis and tumorigenesis gene editing technologies, such as TALENs and CRISPR-Cas nucleases, can be utilized, which allows precise insertion of therapeutic genes into the SC genome without causing dysfunctions of neighboring genes [481]. At the same time, small regulatory RNAs offer a safe possibility to optimize SC potency without altering the genome of the target cell $[482,500]$. As already mentioned for DNA, the introduction of miRs was reported to modulate the paracrine activity of SCs. For instance, MSCs exhibited a 3-fold enhanced release of VEGF when transfected with miR-146, which in turn led to improved pro-angiogenic effects and cardiac performance after transplantation into rats [501]. A similar high level of VEGF expression was induced by application of miR-126 and miR-377 mimics [502-504]. Furthermore, miRs are involved in the regulation of apoptosis and thus have been used to increase the viability of SCs after transplantation [505]. CPCs treated with a miR cocktail containing miR-21, miR-24 and miR-221 survived significantly longer after intramyocardial injection which in turn boost therapeutic efficacy of cells [506]. MiRs have also been proven to be important translational determinants of the SC fate [507]. A combination of 5-azacytine and miR-1 overexpression induces the expression of cardiac specific genes like Nkx2.5 and troponin I via activation of the Wnt/ $\beta$-catenin signaling pathway in MSCs [508, 509]. In addition, miR-133a and miR-499 were shown to promote the commitment of MSCs and CSCs/CPCs towards a cardiomyogenic lineage [510-513]. Likewise, $\mathrm{miR}$ overexpression has been reported to influence the differentiation and maturation of pluripotent SC-derived cardiac cell types [514-516].

\section{Personalized SC therapy}

As discussed above, genetic and non-genetic modifications of cellular properties represent a crucial strategy for the improvement of SC efficiency. At the same time, a system of patient's response predictors need to be developed to identify patients who will benefit most from cardiac SC therapy - a concept which contributes to the field of personalized medicine. Personalized medicine is based on targeted therapeutic treatment, focusing on patient specific characteristics in order to provide the highest quality of therapy, whereas the risk of side effects and costs of ineffective interventions are reduced $[517,518]$.

In 2008, Dimmeler et al. postulated that aging, disease and cardiovascular risk factors, like hypercholesterolemia, hypertension and smoking, not only affect the therapeutic potential of endogenous SCs, but also influence the tissue environment in which cells are transplanted [519]. A collaborative meta-analysis of randomized clinical trials revealed that younger patients and patients with a lower LVEF at baseline derived superior therapeutic benefit from intracoronary BM-derievd cell therapy [385]. These results were confirmed in a post hoc analysis of the REPAIR-AMI trial (NCT00279175) suggesting that higher age is associated with lower treatment benefit, while higher weight and massive initial functional loss are associated with enhanced response to BM-derived MNC therapy [520]. To further discriminate patients beneficially responding to SC application from non-responding patients, a specific responder score is required based on patients' characteristics that enables the classification and selection of patient cohorts. Molecular diagnostics like plasma and blood profiling could help to identify novel biomarkers in order to predict the outcome of SC therapy prior possible intervention. Jokerst and co-workers performed a comprehensive analysis of circulating proteins and cytokines in baseline plasma samples of MI patients that had undergone BM-MNC therapy [521]. They showed that certain biomarkers, like IL-15, IL-5 and stem cell factor (SCF), correlate with an improved cardiac function upon SC treatment indicating that elevated levels of specific circulating cytokines are suitable as selection criteria for personalized cell-based therapies [521]. Likewise, higher serum levels of high-sensitive troponin $\mathrm{T}$ have been attributed to improve the response of patients receiving BM-derived MNC [522]. Recently, in the phase III clinical trial PERFECT our group 
provided evidence that only patients showing an improved cardiac function ( $\triangle \mathrm{LVEF}>5 \%$ ) 6 months after CABG are responsive to intramyocardial CD133 ${ }^{+}$SC application $(\sim 60 \%$ of patients) [99]. In contrast, patients showing no improved LVEF after CABG also failed to respond to SC treatment ( $\sim 40 \%$ of patients). Interestingly, using machine learning we identified 20 parameters, including pre-operative clinical data and biomarker laboratory parameters, such as circulating EPCs, thrombocytes, VEGF, EPO, IP-10, which allow preoperative discrimination between responders and non-responders with an accuracy of $\sim 80 \%$ [99].

In addition, the recent advances in high throughput sequencing technologies bear enormous potential to generate patient specific profiles for their classification as responders vs. non-responders. Data acquired from RNA sequencing provide valuable information about the complex biological networks regulating pathological and physiological processes [523]. Subsequent analysis of these comprehensive data can be used to conclude about gene expression, splice variants, promotor activity, predicted miRNA/long non-coding RNA (lncRNA)-target interactions etc., and thus will allow identification of novel biomarkers for personalized SC-based therapy of CVDs.

\section{Conclusion}

The groundbreaking discoveries of ongoing cardiomyocyte turnover $[170,171]$ and of stem and progenitor cells located in the myocardium [172] identified the human adult heart as an organ bearing potential for self-renewal. However, the limited endogenous degree of cardiac regeneration is insufficient to compensate for the massive loss of cardiomyocytes occurring after acute injury and the consecutive adverse remodeling.

The transplantation of SCs emerged as a new approach to restore damaged myocardial tissue. Encouraging pre-clinical studies reporting significant SC-mediated cardiac regeneration rapidly paved the way for clinical translation. Unfortunately, data from human studies are contradictory, overall showing modest to no therapeutic SC effects [81, 382, 392].

To overcome this discrepancy, a deeper understanding of disease and endogenous reparative mechanisms as well as their interactions with SCs is urgently needed [524]. Indeed, there is growing evidence that patient characteristics, such as disease state, co-morbidities, co-medications and cardiovascular risk factors, critically influence the therapeutic outcome of SC application [99, 385, 520]. This finding clearly demands the implementation of personalized cardiac SC therapies in which the selection of SC source, modification and application is subjected to these individual characteristics [525]. Thus, prospective research should focus on the development of specific responder scores and the identification of prognostic biomarkers to identify patient cohorts who benefit most from distinct SC treatments [526,527]. Thereby, a higher standardization of study designs and the establishment of a global open-access database for the registration and publication of preclinical and clinical trials would greatly improve the comparability and access of obtained data $[526,528,529]$.

\section{Abbreviations}

AMI (Acute myocardial infarction); Ang (Angiopoietin); ASC (Adipose-derived stromal/ stem cell); Bcl (B cell lymphoma); bFGF (Basic fibroblast growth factor); BM (Bone marrow); BMP (Bone morphogenetic protein); CABG (Coronary artery bypass grafting); CCR5 (C-C chemokine receptor type 5); CDC (Cardiosphere-derived cell); CPC (Cardiac progenitor cell); CRISPR (Clustered regularly interspaced short palindromic repeat); CSC (Cardiac stem cell); CVDs (Cardiovascular diseases); CXCR (CXC chemokine receptor); DNA (Deoxyribonucleic acid); ECM (Extracellular matrix); EF (Ejection fraction); EGF (Epidermal growth factor); EPC (Endothelial progenitor cell); EPO (Erythropoietin); ERK (Extracellular 


\section{Cellular Physiology Cell Physiol Biochem 2018;48:2607-2655 \begin{tabular}{ll|l} 
DOI: 10.1159/000492704 & $\begin{array}{l}\text { O 2018 The Author(s). Published by S. Karger AG, Basel } \\
\text { www.karger.com/cpb }\end{array}$ \\
\hline
\end{tabular}

signal-regulated kinase); ESC (Embryonic stem cell); FGF (Fibroblast growth factor); G-CSF (Granulocyte colony-stimulating factor); HF (Heart failure); HGF (Hepatocyte growth factor); HIF (Hypoxia-inducible factor); HLA-G5 (Human leukocyte antigen class I molecule G5); HSC (Hematopoietic stem cell); HSF (Heat shock factor); HSP (Heat shock protein); ICAM-1 (Intercellular adhesion molecule 1); ICM (Chronic ischemic cardiomyopathy); IDO (Indoleamine 2, 3-dioxygenase); IFN (Interferon); IGF (Insulin-like growth factor); IL (Interleukin); ILK (Integrin-linked kinase); iPSC (Induced pluripotent stem cell); Isl (Insulin gene enhancer protein); Klf (Kruppel-like factor); lncRNA (long non-coding RNA); LV (Left ventricular); LVEF (Left ventricular ejection fraction); Ly6C (Lymphocyte antigen 6 complex, locus C); MI (Myocardial infarction); miR (MicroRNA); MMP (Matrix metalloproteinase); MNC (Mononuclear cell); MRI (Magnetic resonance imaging); mRNA (Messenger RNA); MSC (Mesenchymal stromal/stem cell); NK (cell, Natural killer cell); NO (Nitric oxide); NYHA (New York Heart Association); Oct (Octamer-binding transcription factor 4); PB (Peripheral blood); PD-1 (Programmed cell death protein 1); PDE-5 (Phosphodiesterase-5); PLGA (poly(lactic-co-glycolic acid)); PLLA (Poly-L-lactic acid); RNA (Ribonucleic acid); SC (Stem cell); Sca (Stem cell antigen); SCF (Stem cell factor); SDF (Stromal cell-derived factor); siRNA (Short interfering RNA); SSEA (Stage-specific embryonic antigen); SVF (Stroma vascular fraction); TALEN (Transcription activator-like effector nuclease); TGF (Transforming growth factor); TNF (Tumor necrosis factor); Treg (Regulatory T cell); VCAM (Vascular cell adhesion molecule); VEGF (Vascular endothelial growth factor).

\section{Acknowledgements}

We greatly appreciate and acknowledge Sascha Galonska for expert assistance with graphics design. This work was supported by the Federal Ministry of Education and Research Germany (FKZ 0312138A and FKZ 316159), the State Mecklenburg-Western Pomerania with EU Structural Funds (ESF/IVWM-B34-0030/10 and ESF/IVBM-B35-0010/12), the DFG (DA1296-1), the German Heart Foundation (F/01/12) and the BMBF (VIP + 00240). P.M. and H.L. were supported by the FORUN Program of Rostock University Medical Centre (889018 and 889006) and the Käthe und Josef Klinz Foundation (T319/29737/2017). In addition, R.D. is supported by the DAMP Foundation (2016-11).

\section{Disclosure Statement}

The authors declare no conflict of interests.

\section{References}

1 Wilkins E, Wilson L, Wickramasinghe K, Bhatnagar P, Leal J, Luengo-Fernandez R, Burns R, Rayner M, Townsend N: European Cardiovascular Disease Statistics 2017. European Heart Network, Brussels 2017. URL: http://www.ehnheart.org/images/CVD-statistics-report-August-2017.pdf.

$\checkmark 2$ Taylor CJ, Roalfe AK, Iles R, Hobbs FDR: Ten-year prognosis of heart failure in the community: followup data from the Echocardiographic Heart of England Screening (ECHOES) study. Eur J Heart Fail 2012;14:176-184.

3 Hobbs FDR, Roalfe AK, Davis RC, Davies MK, Hare R: Prognosis of all-cause heart failure and borderline left ventricular systolic dysfunction: 5 year mortality follow-up of the Echocardiographic Heart of England Screening Study (ECHOES). Eur Heart J 2007;28:1128-1134.

-4 Orlic D, Kajstura J, Chimenti S, Jakoniuk I, Anderson SM, Li B, Pickel J, McKay R, Nadal-Ginard B, Bodine DM, Leri A, Anversa P: Bone marrow cells regenerate infarcted myocardium. Nature 2001;410:701-705. 


\section{Cellular Physiology Cell Physiol Biochem 2018;48:2607-2655 \begin{tabular}{ll|l} 
and Biochemistry Publisned onIIne: 16 August, 2018 & $\begin{array}{l}\text { (c) } 2018 \text { The Author(s). Published by S. Karger AG, Basel } \\
\text { www.karger.com/cpb }\end{array}$ \\
\hline
\end{tabular}

5 Strauer BE, Brehm M, Zeus T, Gattermann N, Hernandez A, Sorg RV, Kogler G, Wernet P: Intrakoronare, humane autologe Stammzelltransplantation zur Myokardregeneration nach Herzinfarkt. Dtsch Med Wochenschr 2001;126:932-938.

6 Stamm C, Westphal B, Kleine H-D, Petzsch M, Kittner C, Klinge H, Schümichen C, Nienaber CA, Freund M, Steinhoff G: Autologous bone-marrow stem-cell transplantation for myocardial regeneration. The Lancet 2003;361:45-46.

7 Yin H, Price F, Rudnicki MA: Satellite cells and the muscle stem cell niche. Physiol Rev 2013;93:23-67.

-8 Menasche P: Skeletal myoblasts and cardiac repair. J Mol Cell Cardiol 2008;45:545-53.

-9 Bischoff R, Heintz C: Enhancement of skeletal muscle regeneration. Dev Dyn 1994;201:41-54.

10 Buckingham M, Montarras D: Skeletal muscle stem cells. Curr Opin Genet Dev 2008;18:330-3306.

11 Durrani S, Konoplyannikov M, Ashraf M, Haider KH: Skeletal myoblasts for cardiac repair. Regen Med 2010;5:919-932.

-12 Al Attar N, Carrion C, Ghostine S, Garcin I, Vilquin J-T, Hagege AA, Menasche P: Long-term (1 year) functional and histological results of autologous skeletal muscle cells transplantation in rat. Cardiovasc Res 2003;58:142-148.

13 Suzuki K, Murtuza B, Suzuki N, Smolenski RT, Yacoub MH: Intracoronary infusion of skeletal myoblasts improves cardiac function in doxorubicin-induced heart failure. Circulation 2001;104:1213-217.

14 Bonaros N, Rauf R, Wolf D, Margreiter E, Tzankov A, Schlechta B, Kocher A, Ott H, Schachner T, Hering S, Bonatti J, Laufer G: Combined transplantation of skeletal myoblasts and angiopoietic progenitor cells reduces infarct size and apoptosis and improves cardiac function in chronic ischemic heart failure. J Thorac Cardiovasc Surg 2006;132:1321-1328.

15 Farahmand P, Lai TYY, Weisel RD, Fazel S, Yau T, Menasche P, Li R-K: Skeletal myoblasts preserve remote matrix architecture and global function when implanted early or late after coronary ligation into infarcted or remote myocardium. Circulation 2008;118:S130-1307.

16 Fukushima S, Coppen SR, Lee J, Yamahara K, Felkin LE, Terracciano CMN, Barton PJR, Yacoub MH, Suzuki K: Choice of cell-delivery route for skeletal myoblast transplantation for treating post-infarction chronic heart failure in rat. PLoS One 2008;3:e3071.

17 Khan M, Kutala VK, Vikram DS, Wisel S, Chacko SM, Kuppusamy ML, Mohan IK, Zweier JL, Kwiatkowski P, Kuppusamy P: Skeletal myoblasts transplanted in the ischemic myocardium enhance in situ oxygenation and recovery of contractile function. Am J Physiol Heart Circ Physiol 2007;293:H2129-2139.

18 Pouly J, Hagege AA, Vilquin J-T, Bissery A, Rouche A, Bruneval P, Duboc D, Desnos M, Fiszman M, Fromes Y, Menasche P: Does the functional efficacy of skeletal myoblast transplantation extend to nonischemic cardiomyopathy? Circulation 2004;110:1626-1631.

19 Taylor DA, Atkins BZ, Hungspreugs P, Jones TR, Reedy MC, Hutcheson KA, Glower DD, Kraus WE: Regenerating functional myocardium: improved performance after skeletal myoblast transplantation. Nat Med 1998;4:929-933.

20 McCue JD, Swingen C, Feldberg T, Caron G, Kolb A, Denucci C, Prabhu S, Motilall R, Breviu B, Taylor DA: The real estate of myoblast cardiac transplantation: negative remodeling is associated with location. J Heart Lung Transplant 2008;27:116-123.

-21 Atkins BZ, Lewis CW, Kraus WE, Hutcheson KA, Glower DD, Taylor DA: Intracardiac transplantation of skeletal myoblasts yields two populations of striated cells in situ. Ann Thorac Surg 1999;67:124-129.

-22 Ghostine S, Carrion C, Souza LCG, Richard P, Bruneval P, Vilquin J-T, Pouzet B, Schwartz K, Menasche P, Hagege AA: Long-term efficacy of myoblast transplantation on regional structure and function after myocardial infarction. Circulation 2002;106:I131-136.

23 Brasselet C, Morichetti MC, Messas E, Carrion C, Bissery A, Bruneval P, Vilquin J-T, Lafont A, Hagege AA, Menasche P, Desnos M: Skeletal myoblast transplantation through a catheter-based coronary sinus approach: an effective means of improving function of infarcted myocardium. Eur Heart J 2005;26:15511556.

24 Chachques JC, Duarte F, Cattadori B, Shafy A, Lila N, Chatellier G, Fabiani JN, Carpentier AF: Angiogenic growth factors and/or cellular therapy for myocardial regeneration: a comparative study. J Thorac Cardiovasc Surg 2004;128:245-253.

25 Hata H, Matsumiya G, Miyagawa S, Kondoh H, Kawaguchi N, Matsuura N, Shimizu T, Okano T, Matsuda H, Sawa Y: Grafted skeletal myoblast sheets attenuate myocardial remodeling in pacing-induced canine heart failure model. J Thorac Cardiovasc Surg 2006;132:918-924. 


\section{Cellular Physiology Cell Physiol Biochem 2018;48:2607-2655 \begin{tabular}{ll|l} 
and Biochemistry Publisned onIIne: 16 August, 2018 & $\begin{array}{l}\text { (c) } 2018 \text { The Author(s). Published by S. Karger AG, Basel } \\
\text { www.karger.com/cpb }\end{array}$ \\
\hline
\end{tabular}

-26 He K-L, Yi G-H, Sherman W, Zhou H, Zhang G-P, Gu A, Kao R, Haimes HB, Harvey J, Roos E, White D, Taylor DA, Wang J, Burkhoff D: Autologous skeletal myoblast transplantation improved hemodynamics and left ventricular function in chronic heart failure dogs. J Heart Lung Transplant 2005;24:1940-1949.

27 Gavira JJ, Nasarre E, Abizanda G, Perez-Ilzarbe M, Martino-Rodriguez A de, Garcia de Jalon JA, Mazo M, Macias A, Garcia-Bolao I, Pelacho B, Martinez-Caro D, Prosper F: Repeated implantation of skeletal myoblast in a swine model of chronic myocardial infarction. Eur Heart J 2010;31:1013-1021.

-28 Gavira JJ, Perez-Ilzarbe M, Abizanda G, Garcia-Rodriguez A, Orbe J, Paramo JA, Belzunce M, Rabago G, Barba J, Herreros J, Panizo A, Jalon JAG de, Martinez-Caro D, Prosper F: A comparison between percutaneous and surgical transplantation of autologous skeletal myoblasts in a swine model of chronic myocardial infarction. Cardiovasc Res 2006;71:744-753.

-29 Menasche P, Hagege AA, Vilquin J-T, Desnos M, Abergel E, Pouzet B, Bel A, Sarateanu S, Scorsin M, Schwartz K, Bruneval P, Benbunan M, Marolleau J-P, Duboc D: Autologous skeletal myoblast transplantation for severe postinfarction left ventricular dysfunction. J Am Coll Cardiol 2003;41:1078-1083.

30 Smits PC, van Geuns R-JM, Poldermans D, Bountioukos M, Onderwater EEM, Lee CH, Maat APWM, Serruys PW: Catheter-based intramyocardial injection of autologous skeletal myoblasts as a primary treatment of ischemic heart failure: clinical experience with six-month follow-up. J Am Coll Cardiol 2003;42:2063-2069.

- 31 Herreros J, Prosper F, Perez A, Gavira JJ, Garcia-Velloso MJ, Barba J, Sanchez PL, Canizo C, Rabago G, MartiCliment JM, Hernandez M, Lopez-Holgado N, Gonzalez-Santos JM, Martin-Luengo C, Alegria E: Autologous intramyocardial injection of cultured skeletal muscle-derived stem cells in patients with non-acute myocardial infarction. Eur Heart J 2003;24:2012-2020.

-32 Siminiak T, Kalawski R, Fiszer D, Jerzykowska O, Rzezniczak J, Rozwadowska N, Kurpisz M: Autologous skeletal myoblast transplantation for the treatment of postinfarction myocardial injury: phase I clinical study with 12 months of follow-up. Am Heart J 2004;148:531-537.

-33 Dib N, Michler RE, Pagani FD, Wright S, Kereiakes DJ, Lengerich R, Binkley P, Buchele D, Anand I, Swingen C, Di Carli MF, Thomas JD, Jaber WA, Opie SR, Campbell A, McCarthy P, Yeager M, Dilsizian V, Griffith BP, Korn R, et al.: Safety and feasibility of autologous myoblast transplantation in patients with ischemic cardiomyopathy: four-year follow-up. Circulation 2005;112:1748-1755.

34 Gavira JJ, Herreros J, Perez A, Garcia-Velloso MJ, Barba J, Martin-Herrero F, Canizo C, Martin-Arnau A, MartiCliment JM, Hernandez M, Lopez-Holgado N, Gonzalez-Santos JM, Martin-Luengo C, Alegria E, Prosper F: Autologous skeletal myoblast transplantation in patients with nonacute myocardial infarction: 1-year follow-up. J Thorac Cardiovasc Surg 2006;131:799-804.

-35 Ince H, Petzsch M, Rehders TC, Chatterjee T, Nienaber CA: Transcatheter transplantation of autologous skeletal myoblasts in postinfarction patients with severe left ventricular dysfunction. J Endovasc Ther 2004;11:695-704.

-36 Siminiak T, Fiszer D, Jerzykowska O, Grygielska B, Rozwadowska N, Kalmucki P, Kurpisz M: Percutaneous trans-coronary-venous transplantation of autologous skeletal myoblasts in the treatment of post-infarction myocardial contractility impairment: the POZNAN trial. Eur Heart J 2005;26:1188-1195.

-37 Biagini E, Valgimigli M, Smits PC, Poldermans D, Schinkel AFL, Rizzello V, Onderwater EEM, Bountioukos M, Serruys PW: Stress and tissue Doppler echocardiographic evidence of effectiveness of myoblast transplantation in patients with ischaemic heart failure. Eur J Heart Fail 2006;8:641-648.

-38 Hagege AA, Marolleau J-P, Vilquin J-T, Alheritiere A, Peyrard S, Duboc D, Abergel E, Messas E, Mousseaux E, Schwartz K, Desnos M, Menasche P: Skeletal myoblast transplantation in ischemic heart failure: long-term follow-up of the first phase I cohort of patients. Circulation 2006;114:I108-113.

-39 Veltman CE, Soliman OII, Geleijnse ML, Vletter WB, Smits PC, ten Cate FJ, Jordaens LJ, Balk AHHM, Serruys PW, Boersma E, van Domburg RT, van der Giessen WJ: Four-year follow-up of treatment with intramyocardial skeletal myoblasts injection in patients with ischaemic cardiomyopathy. Eur Heart J 2008;29:1386-1396.

40 Reinecke H, Poppa V, Murry CE: Skeletal muscle stem cells do not transdifferentiate into cardiomyocytes after cardiac grafting. J Mol Cell Cardiol 2002;34:241-924.

41 Leobon B, Garcin I, Menasche P, Vilquin J-T, Audinat E, Charpak S: Myoblasts transplanted into rat infarcted myocardium are functionally isolated from their host. Proc Natl Acad Sci U S A 2003;100:7808-7411.

-42 Abraham MR, Henrikson CA, Tung L, Chang MG, Aon M, Xue T, Li RA, O’ Rourke B, Marban E: Antiarrhythmic engineering of skeletal myoblasts for cardiac transplantation. Circ Res 2005;97:159-167. 


\section{Cellular Physiology Cell Physiol Biochem 2018;48:2607-2655 \begin{tabular}{ll|l} 
DOI: 10.1159/000492704 & $\begin{array}{l}\text { O 2018 The Author(s). Published by S. Karger AG, Basel } \\
\text { www.karger.com/cpb }\end{array}$
\end{tabular} \\ Müller et al.: Cardiac Stem Cell Therapy}

43 Menasche P, Alfieri O, Janssens S, McKenna W, Reichenspurner H, Trinquart L, Vilquin J-T, Marolleau J-P, Seymour B, Larghero J, Lake S, Chatellier G, Solomon S, Desnos M, Hagege AA: The Myoblast Autologous Grafting in Ischemic Cardiomyopathy (MAGIC) trial: first randomized placebo-controlled study of myoblast transplantation. Circulation 2008;117:1189-1200.

44 Dib N, Dinsmore J, Lababidi Z, White B, Moravec S, Campbell A, Rosenbaum A, Seyedmadani K, Jaber WA, Rizenhour CS, Diethrich E: One-year follow-up of feasibility and safety of the first U.S., randomized, controlled study using 3-dimensional guided catheter-based delivery of autologous skeletal myoblasts for ischemic cardiomyopathy (CAuSMIC study). JACC Cardiovasc Interv 2009;2:9-16.

-45 Duckers HJ, Houtgraaf J, Hehrlein C, Schofer J, Waltenberger J, Gershlick A, Bartunek J, Nienaber C, Macaya C, Peters N, Smits P, Siminiak T, van Mieghem W, Legrand V, Serruys PW: Final results of a phase IIa, randomised, open-label trial to evaluate the percutaneous intramyocardial transplantation of autologous skeletal myoblasts in congestive heart failure patients: the SEISMIC trial. EuroIntervention 2011;6:805812.

-46 Povsic TJ, O’Connor CM, Henry T, Taussig A, Kereiakes DJ, Fortuin FD, Niederman A, Schatz R, Spencer R 4th, Owens D, Banks M, Joseph D, Roberts R, Alexander JH, Sherman W: A double-blind, randomized, controlled, multicenter study to assess the safety and cardiovascular effects of skeletal myoblast implantation by catheter delivery in patients with chronic heart failure after myocardial infarction. Am Heart J 2011;162:654-662.e1.

47 Brickwedel J, Gulbins H, Reichenspurner H: Long-term follow-up after autologous skeletal myoblast transplantation in ischaemic heart disease. Interact Cardiovasc Thorac Surg 2014;18:61-66.

-48 Ferrari G, Cusella-De Angelis G, Coletta M, Paolucci E, Stornaiuolo A, Cossu G, Mavilio F: Muscle regeneration by bone marrow-derived myogenic progenitors. Science 1998;279:1528-1530.

-49 Eglitis MA, Mezey E: Hematopoietic cells differentiate into both microglia and macroglia in the brains of adult mice. Proc Natl Acad Sci U S A 1997;94:4080-4085.

-50 Theise ND, Nimmakayalu M, Gardner R, Illei PB, Morgan G, Teperman L, Henegariu O, Krause DS: Liver from bone marrow in humans. Hepatology 2000;32:11-16.

51 Brazelton TR, Rossi FM, Keshet GI, Blau HM: From marrow to brain: expression of neuronal phenotypes in adult mice. Science 2000;290:1775-1779.

52 Bittner RE, Schofer C, Weipoltshammer K, Ivanova S, Streubel B, Hauser E, Freilinger M, Hoger H, ElbeBurger A, Wachtler F: Recruitment of bone-marrow-derived cells by skeletal and cardiac muscle in adult dystrophic mdx mice. Anat Embryol (Berl) 1999;199:391-396.

53 Malliaras K, Marban E: Cardiac cell therapy: where we've been, where we are, and where we should be headed. Br Med Bull 2011;98:161-185.

54 Dimmeler S, Zeiher AM: Cell therapy of acute myocardial infarction: open questions. Cardiology 2009;113:155-160.

-55 Strauer BE, Brehm M, Zeus T, Kostering M, Hernandez A, Sorg RV, Kogler G, Wernet P: Repair of infarcted myocardium by autologous intracoronary mononuclear bone marrow cell transplantation in humans. Circulation 2002;106:1913-1918.

-56 Choudhury T, Mozid A, Hamshere S, Yeo C, Pellaton C, Arnous S, Saunders N, Brookman P, Jain A, Locca D, Archbold A, Knight C, Wragg A, Davies C, Mills P, Parmar M, Rothman M, Choudry F, Jones DA, Agrawal S, et al.: An exploratory randomized control study of combination cytokine and adult autologous bone marrow progenitor cell administration in patients with ischaemic cardiomyopathy: the REGENERATE-IHD clinical trial. Eur J Heart Fail 2017;19:138-147.

-57 Schachinger V, Erbs S, Elsasser A, Haberbosch W, Hambrecht R, Holschermann H, Yu J, Corti R, Mathey DG, Hamm CW, Suselbeck T, Assmus B, Tonn T, Dimmeler S, Zeiher AM: Intracoronary bone marrow-derived progenitor cells in acute myocardial infarction. N Engl J Med 2006;355:1210-1221.

58 Wollert KC, Meyer GP, Lotz J, Ringes Lichtenberg S, Lippolt P, Breidenbach C, Fichtner S, Korte T, Hornig B, Messinger D, Arseniev L, Hertenstein B, Ganser A, Drexler H: Intracoronary autologous bone-marrow cell transfer after myocardial infarction: The BOOST randomised controlled clinical trial. The Lancet 2004;364:141-148.

-59 Huikuri HV, Kervinen K, Niemela M, Ylitalo K, Saily M, Koistinen P, Savolainen E-R, Ukkonen H, Pietila M, Airaksinen JKE, Knuuti J, Makikallio TH: Effects of intracoronary injection of mononuclear bone marrow cells on left ventricular function, arrhythmia risk profile, and restenosis after thrombolytic therapy of acute myocardial infarction. Eur Heart J 2008;29:2723-2732. 


\section{Cellular Physiology Cell Physiol Biochem 2018;48:2607-2655 \begin{tabular}{ll|l} 
and Biochemistry Publisned onIIne: 16 August, 2018 & $\begin{array}{l}\text { (c) } 2018 \text { The Author(s). Published by S. Karger AG, Basel } \\
\text { www.karger.com/cpb }\end{array}$ \\
\hline
\end{tabular}

60 Assmus B, Walter DH, Seeger FH, Leistner DM, Steiner J, Ziegler I, Lutz A, Khaled W, Klotsche J, Tonn T, Dimmeler S, Zeiher AM: Effect of shock wave-facilitated intracoronary cell therapy on LVEF in patients with chronic heart failure: the CELLWAVE randomized clinical trial. JAMA 2013;309:1622-1631.

-61 Pokushalov E, Romanov A, Chernyavsky A, Larionov P, Terekhov I, Artyomenko S, Poveshenko 0, Kliver E, Shirokova N, Karaskov A, Dib N: Efficiency of intramyocardial injections of autologous bone marrow mononuclear cells in patients with ischemic heart failure: a randomized study. J Cardiovasc Transl Res 2010;3:160-168.

-62 Zhao Q Sun Y, Xia L, Chen A, Wang Z: Randomized study of mononuclear bone marrow cell transplantation in patients with coronary surgery. Ann Thorac Surg 2008;86:1833-1840.

-63 Hu S, Liu S, Zheng Z, Yuan X, Li L, Lu M, Shen R, Duan F, Zhang X, Li J, Liu X, Song Y, Wang W, Zhao S, He Z, Zhang H, Yang K, Feng W, Wang X: Isolated coronary artery bypass graft combined with bone marrow mononuclear cells delivered through a graft vessel for patients with previous myocardial infarction and chronic heart failure: a single-center, randomized, double-blind, placebo-controlled clinical trial. J Am Coll Cardiol 2011;57:2409-2415.

64 Lu M, Liu S, Zheng Z, Yin G, Song L, Chen H, Chen X, Chen Q Jiang S, Tian L, He Z, Hu S, Zhao S: A pilot trial of autologous bone marrow mononuclear cell transplantation through grafting artery: a sub-study focused on segmental left ventricular function recovery and scar reduction. Int J Cardiol 2013;168:2221-2227.

65 Traverse JH, Henry TD, Ellis SG, Pepine CJ, Willerson JT, Zhao DXM, Forder JR, Byrne BJ, Hatzopoulos AK, Penn MS, Perin EC, Baran KW, Chambers J, Lambert C, Raveendran G, Simon DI, Vaughan DE, Simpson LM, Gee AP, Taylor DA, et al.: Effect of intracoronary delivery of autologous bone marrow mononuclear cells 2 to 3 weeks following acute myocardial infarction on left ventricular function: the LateTIME randomized trial. JAMA 2011;306:2110-2119.

-66 Perin EC, Willerson JT, Pepine CJ, Henry TD, Ellis SG, Zhao DXM, Silva GV, Lai D, Thomas JD, Kronenberg MW, Martin AD, Anderson RD, Traverse JH, Penn MS, Anwaruddin S, Hatzopoulos AK, Gee AP, Taylor DA, Cogle CR, Smith D, et al.: Effect of transendocardial delivery of autologous bone marrow mononuclear cells on functional capacity, left ventricular function, and perfusion in chronic heart failure: the FOCUS-CCTRN trial. JAMA 2012;307:1717-1726.

67 Patila T, Lehtinen M, Vento A, Schildt J, Sinisalo J, Laine M, Hammainen P, Nihtinen A, Alitalo R, Nikkinen P, Ahonen A, Holmstrom M, Lauerma K, Poyhia R, Kupari M, Kankuri E, Harjula A: Autologous bone marrow mononuclear cell transplantation in ischemic heart failure: a prospective, controlled, randomized, doubleblind study of cell transplantation combined with coronary bypass. J Heart Lung Transplant 2014;33:567574.

68 Sant'Anna RT, Fracasso J, Valle FH, Castro I, Nardi NB, Sant'Anna JRM, Nesralla IA, Kalil RAK: Direct intramyocardial transthoracic transplantation of bone marrow mononuclear cells for non-ischemic dilated cardiomyopathy: INTRACELL, a prospective randomized controlled trial. Rev Bras Cir Cardiovasc 2014;29:437-447.

69 Martino H, Brofman P, Greco O, Bueno R, Bodanese L, Clausell N, Maldonado JA, Mill J, Braile D, Moraes J JR, Silva S, Bozza A, Santos B, Campos de Carvalho A: Multicentre, randomized, double-blind trial of intracoronary autologous mononuclear bone marrow cell injection in non-ischaemic dilated cardiomyopathy (the dilated cardiomyopathy arm of the MiHeart study). Eur Heart J 2015;36:2898-2904.

-70 Ang K-L, Chin D, Leyva F, Foley P, Kubal C, Chalil S, Srinivasan L, Bernhardt L, Stevens S, Shenje LT, Galinanes M: Randomized, controlled trial of intramuscular or intracoronary injection of autologous bone marrow cells into scarred myocardium during CABG versus CABG alone. Nat Clin Pract Cardiovasc Med 2008;5:663670.

71 Lunde K, Solheim S, Aakhus S, Arnesen H, Abdelnoor M, Egeland T, Endresen K, Ilebekk A, Mangschau A, Fjeld JG, Smith HJ, Taraldsrud E, Grogaard HK, Bjornerheim R, Brekke M, Muller C, Hopp E, Ragnarsson A, Brinchmann JE, Forfang K: Intracoronary injection of mononuclear bone marrow cells in acute myocardial infarction. N Engl J Med 2006;355:1199-1209.

72 Hirsch A, Nijveldt R, van der Vleuten PA, Tijssen JGP, van der Giessen WJ, Tio RA, Waltenberger J, ten Berg JM, Doevendans PA, Aengevaeren WRM, Zwaginga JJ, Biemond BJ, van Rossum AC, Piek JJ, Zijlstra F: Intracoronary infusion of mononuclear cells from bone marrow or peripheral blood compared with standard therapy in patients after acute myocardial infarction treated by primary percutaneous coronary intervention: results of the randomized controlled HEBE trial. Eur Heart J 2011;32:1736-1747. 


\section{Cellular Physiology Cell Physiol Biochem 2018;48:2607-2655 \begin{tabular}{ll|l} 
and Biochemistry Publisned onIIne: 16 August, 2018 & $\begin{array}{l}\text { (c) } 2018 \text { The Author(s). Published by S. Karger AG, Basel } \\
\text { www.karger.com/cpb }\end{array}$ \\
\hline
\end{tabular} \\ Müller et al.: Cardiac Stem Cell Therapy}

73 Surder D, Manka R, Lo Cicero V, Moccetti T, Rufibach K, Soncin S, Turchetto L, Radrizzani M, Astori G, Schwitter J, Erne P, Zuber M, Maur C auf der, Jamshidi P, Gaemperli O, Windecker S, Moschovitis A, Wahl A, Buhler I, Wyss C, et al.: Intracoronary injection of bone marrow-derived mononuclear cells early or late after acute myocardial infarction: effects on global left ventricular function. Circulation 2013;127:19681979.

74 Heldman AW, DiFede DL, Fishman JE, Zambrano JP, Trachtenberg BH, Karantalis V, Mushtaq M, Williams AR, Suncion VY, McNiece IK, Ghersin E, Soto V, Lopera G, Miki R, Willens H, Hendel R, Mitrani R, Pattany P, Feigenbaum G, Oskouei B, et al.: Transendocardial mesenchymal stem cells and mononuclear bone marrow cells for ischemic cardiomyopathy: the TAC-HFT randomized trial. JAMA 2014;311:62-73.

-75 Santoso T, Siu C-W, Irawan C, Chan W-S, Alwi I, Yiu K-H, Aziz A, Kwong Y-L, Tse H-F: Endomyocardial implantation of autologous bone marrow mononuclear cells in advanced ischemic heart failure: a randomized placebo-controlled trial (END-HF). J Cardiovasc Transl Res 2014;7:545-552.

-76 Traverse JH, Henry TD, Pepine CJ, Willerson JT, Chugh AR, Yang PC, Zhao D, Ellis SG, Forder JR, Perin EC, Penn MS, Hatzopoulos AK, Chambers JW, Baran K, Raveendran G, Gee AP, Taylor DA, Moyé L, Ebert RF, Simari RD: The TIME Trial - Effect of Timing of Stem Cell Delivery Following ST-Elevation Myocardial Infarction on the Recovery of Global and Regional Left Ventricular Function: Final 2-Year Analysis. Circ Res 2017.

77 Sadat K, Ather S, Aljaroudi W, Heo J, Iskandrian AE, Hage FG: The effect of bone marrow mononuclear stem cell therapy on left ventricular function and myocardial perfusion. J Nucl Cardiol 2014;21:351-367.

-78 Wen Y, Chen B, Wang C, Ma X, Gao Q: Bone marrow-derived mononuclear cell therapy for patients with ischemic heart disease and ischemic heart failure. Expert Opin Biol Ther 2012;12:1563-1573.

-79 Ye Z, Zhang BL, Zhao XX, Qin YW, Wu H, Cao J, Zhang JL, Hu JQ, Zheng X, Xu RL: Intracoronary infusion of bone marrow-derived mononuclear cells contributes to longstanding improvements of left ventricular performance and remodelling after acute myocardial infarction: a meta-analysis. Heart Lung Circ $2012 ; 21: 725-733$.

-80 Jong R de, Houtgraaf JH, Samiei S, Boersma E, Duckers HJ: Intracoronary stem cell infusion after acute myocardial infarction: a meta-analysis and update on clinical trials. Circ Cardiovasc Interv 2014;7:156-167.

-81 Jeevanantham V, Butler M, Saad A, Abdel-Latif A, Zuba-Surma EK, Dawn B: Adult bone marrow cell therapy improves survival and induces long-term improvement in cardiac parameters: a systematic review and meta-analysis. Circulation 2012;126:551-568.

82 Traverse JH, Henry TD, Moye' LA: Is the measurement of left ventricular ejection fraction the proper end point for cell therapy trials? An analysis of the effect of bone marrow mononuclear stem cell administration on left ventricular ejection fraction after ST-segment elevation myocardial infarction when evaluated by cardiac magnetic resonance imaging. Am Heart J 2011;162:671-677.

83 Eaves CJ: Hematopoietic stem cells: Concepts, definitions, and the new reality. Blood 2015;125:2605-2613.

84 Asahara T, Kawamoto A, Masuda H: Concise review: Circulating endothelial progenitor cells for vascular medicine. Stem Cells 2011;29:1650-1655.

-85 Asahara T: Isolation of Putative Progenitor Endothelial Cells for Angiogenesis. Science 1997;275:964-966.

-86 Yoder MC: Human endothelial progenitor cells. Cold Spring Harb Perspect Med 2012;2:a006692.

-87 Takizawa S, Nagata E, Nakayama T, Masuda H, Asahara T: Recent Progress in Endothelial Progenitor Cell Culture Systems: Potential for Stroke Therapy. Neurol Med Chir (Tokyo) 2016;56:302-309.

-88 Stamm C, Kleine H-D, Choi Y-H, Dunkelmann S, Lauffs J-A, Lorenzen B, David A, Liebold A, Nienaber C, Zurakowski D, Freund M, Steinhoff G: Intramyocardial delivery of CD133+ bone marrow cells and coronary artery bypass grafting for chronic ischemic heart disease: safety and efficacy studies. J Thorac Cardiovasc Surg 2007;133:717-725.

89 Ahmadi H, Baharvand H, Ashtiani SK, Soleimani M, Sadeghian H, Ardekani JM, Mehrjerdi NZ, Kouhkan A, Namiri M, Madani-Civi M, Fattahi F, Shahverdi A, Dizaji AV: Safety analysis and improved cardiac function following local autologous transplantation of CD133(+) enriched bone marrow cells after myocardial infarction. Curr Neurovasc Res 2007;4:153-160.

-90 Forcillo J, Stevens LM, Mansour S, Prieto I, Salem R, Baron C, Roy DC, Larose E, Masckauchan D, Noiseux N: Implantation of CD133+ stem cells in patients undergoing coronary bypass surgery: IMPACT-CABG pilot trial. Can J Cardiol 2013;29:441-447. 


\section{Cellular Physiology Cell Physiol Biochem 2018;48:2607-2655 \begin{tabular}{ll|l} 
and Biochemistry Publisned onIIne: 16 August, 2018 & $\begin{array}{l}\text { (c) } 2018 \text { The Author(s). Published by S. Karger AG, Basel } \\
\text { www.karger.com/cpb }\end{array}$ \\
\hline
\end{tabular} \\ Müller et al.: Cardiac Stem Cell Therapy}

-91 Erbs S, Linke A, Schachinger V, Assmus B, Thiele H, Diederich K-W, Hoffmann C, Dimmeler S, Tonn T, Hambrecht R, Zeiher AM, Schuler G: Restoration of microvascular function in the infarct-related artery by intracoronary transplantation of bone marrow progenitor cells in patients with acute myocardial infarction: the Doppler Substudy of the Reinfusion of Enriched Progenitor Cells and Infarct Remodeling in Acute Myocardial Infarction (REPAIR-AMI) trial. Circulation 2007;116:366-374.

$\$ 92$ Manginas A, Goussetis E, Koutelou M, Karatasakis G, Peristeri I, Theodorakos A, Leontiadis E, Plessas N, Theodosaki M, Graphakos S, Cokkinos DV: Pilot study to evaluate the safety and feasibility of intracoronary CD133(+) and CD133(-) CD34(+) cell therapy in patients with nonviable anterior myocardial infarction. Catheter Cardiovasc Interv 2007;69:773-781.

$\$ 93$ Colombo A, Castellani M, Piccaluga E, Pusineri E, Palatresi S, Longari V, Canzi C, Sacchi E, Rossi E, Rech R, Gerundini P, Viecca M, Deliliers GL, Rebulla P, Soligo D, Giordano R: Myocardial blood flow and infarct size after CD133+ cell injection in large myocardial infarction with good recanalization and poor reperfusion: results from a randomized controlled trial. J Cardiovasc Med (Hagerstown) 2011;12:239-248.

$\$ 94$ Klein HM, Ghodsizad A, Marktanner R, Poll L, Voelkel T, Mohammad Hasani MR, Piechaczek C, Feifel N, Stockschlaeder M, Burchardt ER, Kar BJ, Gregoric I, Gams E: Intramyocardial implantation of CD133+ stem cells improved cardiac function without bypass surgery. Heart Surg Forum 2007;10:E66-69.

95 Bartunek J, Vanderheyden M, Vandekerckhove B, Mansour S, Bruyne B de, Bondt P de, van Haute I, Lootens N, Heyndrickx G, Wijns W: Intracoronary injection of CD133-positive enriched bone marrow progenitor cells promotes cardiac recovery after recent myocardial infarction: feasibility and safety. Circulation 2005;112:I178-183.

-96 Yerebakan C, Kaminski A, Westphal B, Donndorf P, Glass A, Liebold A, Stamm C, Steinhoff G: Impact of preoperative left ventricular function and time from infarction on the long-term benefits after intramyocardial CD133(+) bone marrow stem cell transplant. J Thorac Cardiovasc Surg 2011;142:15301539.e3.

\$7 Ahmadi H, Farahani MM, Kouhkan A, Moazzami K, Fazeli R, Sadeghian H, Namiri M, Madani-Civi M, Baharvand H, Aghdami N: Five-year follow-up of the local autologous transplantation of CD133+ enriched bone marrow cells in patients with myocardial infarction. Arch Iran Med 2012;15:32-35.

-98 Nasseri BA, Ebell W, Dandel M, Kukucka M, Gebker R, Doltra A, Knosalla C, Choi Y-H, Hetzer R, Stamm C: Autologous CD133+ bone marrow cells and bypass grafting for regeneration of ischaemic myocardium: the Cardio133 trial. Eur Heart J 2014;35:1263-1274.

\$99 Steinhoff G, Nesteruk J, Wolfien M, Kundt G, Börgermann J, David R, Garbade J, Große J, Haverich A, Hennig H, Kaminski A, Lotz J, Mohr FW, Müller P, Oostendorp R, Ruch U, Sarikouch S, Skorska A, Stamm C, Tiedemann G, et al.: Cardiac Function Improvement and Bone Marrow Response -: Outcome Analysis of the Randomized PERFECT Phase III Clinical Trial of Intramyocardial CD133(+) Application After Myocardial Infarction. EBioMedicine 2017.

100 Patel AN, Geffner L, Vina RF, Saslavsky J, Urschel HC JR, Kormos R, Benetti F: Surgical treatment for congestive heart failure with autologous adult stem cell transplantation: a prospective randomized study. J Thorac Cardiovasc Surg 2005;130:1631-1638.

101 Oakley RE, Al msherqi Z, Lim SK, Lee S-H, Ho KT, Sutandar A, Lee CN, Lim YT: Transplantation of autologous bone marrow-derived cells into the myocardium of patients undergoing coronary bypass. Heart Surg Forum 2005;8:E348-350.

102 Wang S, Cui J, Peng W, Lu M: Intracoronary autologous CD34+ stem cell therapy for intractable angina. Cardiology 2010;117:140-147.

103 Quyyumi AA, Waller EK, Murrow J, Esteves F, Galt J, Oshinski J, Lerakis S, Sher S, Vaughan D, Perin E, Willerson J, Kereiakes D, Gersh BJ, Gregory D, Werner A, Moss T, Chan WS, Preti R, Pecora AL: CD34(+) cell infusion after ST elevation myocardial infarction is associated with improved perfusion and is dose dependent. Am Heart J 2011;161:98-105.

104 Tendera M, Wojakowski W, Ruzyllo W, Chojnowska L, Kepka C, Tracz W, Musialek P, Piwowarska W, Nessler J, Buszman P, Grajek S, Breborowicz P, Majka M, Ratajczak MZ: Intracoronary infusion of bone marrowderived selected CD34+CXCR4+ cells and non-selected mononuclear cells in patients with acute STEMI and reduced left ventricular ejection fraction: Results of randomized, multicentre Myocardial Regeneration by Intracoronary Infusion of Selected Population of Stem Cells in Acute Myocardial Infarction (REGENT) Trial. Eur Heart J 2009;30:1313-1321. 


\section{Cellular Physiology Cell Physiol Biochem 2018;48:2607-2655 \begin{tabular}{ll|l} 
and Biochemistry Published onlIne: 16 August, 2018 & $\begin{array}{l}\text { (c) } 2018 \text { The Author(s). Published by S. Karger AG, Basel } \\
\text { www.karger.com/cpb }\end{array}$
\end{tabular} \\ Müller et al.: Cardiac Stem Cell Therapy}

105 Pittenger MF, Mackay AM, Beck SC, Jaiswal RK, Douglas R, Mosca JD, Moorman MA, Simonetti DW, Craig S, Marshak DR: Multilineage potential of adult human mesenchymal stem cells. Science 1999;284:143-147.

106 Dominici M, Le Blanc K, Mueller I, Slaper-Cortenbach I, Marini F, Krause D, Deans R, Keating A, Prockop D, Horwitz E: Minimal criteria for defining multipotent mesenchymal stromal cells. The International Society for Cellular Therapy position statement. Cytotherapy 2006;8:315-317.

107 Karantalis V, Schulman IH, Balkan W, Hare JM: Allogeneic cell therapy: A new paradigm in therapeutics. Circ Res 2015;116:12-15.

108 Kanelidis AJ, Premer C, Lopez J, Balkan W, Hare JM: Route of Delivery Modulates the Efficacy of Mesenchymal Stem Cell Therapy for Myocardial Infarction: A Meta-Analysis of Preclinical Studies and Clinical Trials. Circ Res 2017;120:1139-1150.

109 Karantalis V, DiFede DL, Gerstenblith G, Pham S, Symes J, Zambrano JP, Fishman J, Pattany P, McNiece I, Conte J, Schulman S, Wu K, Shah A, Breton E, Davis-Sproul J, Schwarz R, Feigenbaum G, Mushtaq M, Suncion VY, Lardo AC, et al.: Autologous mesenchymal stem cells produce concordant improvements in regional function, tissue perfusion, and fibrotic burden when administered to patients undergoing coronary artery bypass grafting: The Prospective Randomized Study of Mesenchymal Stem Cell Therapy in Patients Undergoing Cardiac Surgery (PROMETHEUS) trial. Circ Res 2014;114:1302-1310.

110 Chen SL, Fang WW, Ye F, Liu YH, Qian J, Shan SJ, Zhang JJ, Chunhua RZ, Liao LM, Lin S, Sun JP: Effect on left ventricular function of intracoronary transplantation of autologous bone marrow mesenchymal stem cell in patients with acute myocardial infarction. Am J Cardiol 2004;94:92-95.

111 Lee JW, Lee SH, Youn YJ, Ahn MS, Kim JY, Yoo BS, Yoon J, Kwon W, Hong IS, Lee K, Kwan J, Park KS, Choi D, Jang YS, Hong MK: A randomized, open-label, multicenter trial for the safety and efficacy of adult mesenchymal stem cells after acute myocardial infarction. J Korean Med Sci 2014;29:23-31.

$\checkmark 112$ Mathiasen AB, Qayyum AA, Jorgensen E, Helqvist S, Fischer-Nielsen A, Kofoed KF, Haack-Sorensen M, Ekblond A, Kastrup J: Bone marrow-derived mesenchymal stromal cell treatment in patients with severe ischaemic heart failure: A randomized placebo-controlled trial (MSC-HF trial). Eur Heart J 2015;36:17441753.

113 Gao LR, Pei XT, Ding QA, Chen Y, Zhang NK, Chen HY, Wang ZG, Wang YF, Zhu ZM, Li TC, Liu HL, Tong ZC, Yang Y, Nan X, Guo F, Shen JL, Shen YH, Zhang JJ, Fei YX, Xu HT, et al.: A critical challenge: Dosage-related efficacy and acute complication intracoronary injection of autologous bone marrow mesenchymal stem cells in acute myocardial infarction. Int J Cardiol 2013;168:3191-3199.

114 Wang X, Xi W-C, Wang F: The beneficial effects of intracoronary autologous bone marrow stem cell transfer as an adjunct to percutaneous coronary intervention in patients with acute myocardial infarction. Biotechnol Lett 2014;36:2163-2168.

115 Wang JA, Xie XJ, He H, Sun Y, Jiang J, Luo RH, Fan YQ, Dong L: A prospective, randomized, controlled trial of autologous mesenchymal stem cells transplantation for dilated cardiomyopathy. Zhonghua Xin Xue Guan Bing Za Zhi 2006;34:107-110.

116 Perin EC, Borow KM, Silva GV, DeMaria AN, Marroquin OC, Huang PP, Traverse JH, Krum H, Skerrett D, Zheng Y, Willerson JT, Itescu S, Henry TD: A Phase II Dose-Escalation Study of Allogeneic Mesenchymal Precursor Cells in Patients With Ischemic or Nonischemic Heart Failure. Circ Res 2015;117:576-584.

-117 Chullikana A, Majumdar AS, Gottipamula S, Krishnamurthy S, Kumar AS, Prakash VS, Gupta PK: Randomized, double-blind, phase I/II study of intravenous allogeneic mesenchymal stromal cells in acute myocardial infarction. Cytotherapy 2015;17:250-261.

118 Jansen Of Lorkeers SJ, Eding JEC, Vesterinen HM, van der Spoel TIG, Sena ES, Duckers HJ, Doevendans PA, Macleod MR, Chamuleau SAJ: Similar effect of autologous and allogeneic cell therapy for ischemic heart disease: Systematic review and meta-analysis of large animal studies. Circ Res 2015;116:80-86.

119 Hare JM, Fishman JE, Gerstenblith G, DiFede Velazquez DL, Zambrano JP, Suncion VY, Tracy M, Ghersin E, Johnston PV, Brinker JA, Breton E, Davis-Sproul J, Schulman IH, Byrnes J, Mendizabal AM, Lowery MH, Rouy D, Altman P, Wong Po Foo C, Ruiz P, et al.: Comparison of allogeneic vs autologous bone marrow-derived mesenchymal stem cells delivered by transendocardial injection in patients with ischemic cardiomyopathy: The POSEIDON randomized trial. JAMA 2012;308:2369-2379.

120 Hare JM, DiFede DL, Rieger AC, Florea V, Landin AM, El-Khorazaty J, Khan A, Mushtaq M, Lowery MH, Byrnes JJ, Hendel RC, Cohen MG, Alfonso CE, Valasaki K, Pujol MV, Golpanian S, Ghersin E, Fishman JE, Pattany P, Gomes SA, et al.: Randomized Comparison of Allogeneic Versus Autologous Mesenchymal Stem Cells for Nonischemic Dilated Cardiomyopathy: POSEIDON-DCM Trial. J Am Coll Cardiol 2017;69:526-537. 


\section{Cellular Physiology Cell Physiol Biochem 2018;48:2607-2655 \begin{tabular}{ll|l} 
and Biochemistry Published onIIne: 16 August, 2018 & $\begin{array}{l}\text { (c) } 2018 \text { The Author(s). Published by S. Karger AG, Basel } \\
\text { www.karger.com/cpb }\end{array}$ \\
\hline
\end{tabular}

121 Anversa P, Kajstura J, Leri A: Circulating progenitor cells: Search for an identity. Circulation 2004;110:3158-60.

122 Korbling M: Peripheral blood stem cell versus bone marrow allotransplantation: Does the source of hematopoietic stem cells matter? Blood 2001;98:2900-2908.

123 Wojakowski W, Tendera M, Michalowska A, Majka M, Kucia M, Maslankiewicz K, Wyderka R, Ochala A, Ratajczak MZ: Mobilization of CD34/CXCR4+, CD34/CD117+, c-met+ stem cells, and mononuclear cells expressing early cardiac, muscle, and endothelial markers into peripheral blood in patients with acute myocardial infarction. Circulation 2004;110:3213-3220.

124 Wojakowski W, Tendera M, Zebzda A, Michalowska A, Majka M, Kucia M, Maslankiewicz K, Wyderka R, Krol M, Ochala A, Kozakiewicz K, Ratajczak MZ: Mobilization of CD34(+), CD117(+), CXCR4(+), c-met(+) stem cells is correlated with left ventricular ejection fraction and plasma NT-proBNP levels in patients with acute myocardial infarction. Eur Heart J 2006;27:283-289.

125 Massa M, Rosti V, Ferrario M, Campanelli R, Ramajoli I, Rosso R, Ferrari GM de, Ferlini M, Goffredo L, Bertoletti A, Klersy C, Pecci A, Moratti R, Tavazzi L: Increased circulating hematopoietic and endothelial progenitor cells in the early phase of acute myocardial infarction. Blood 2005;105:199-206.

126 Leone AM, Rutella S, Bonanno G, Abbate A, Rebuzzi AG, Giovannini S, Lombardi M, Galiuto L, Liuzzo G, Andreotti F, Lanza GA, Contemi AM, Leone G, Crea F: Mobilization of bone marrow-derived stem cells after myocardial infarction and left ventricular function. Eur Heart J 2005;26:1196-1204.

127 Sheridan WP, Begley CG, Juttner CA, Szer J, To LB, Maher D, McGrath KM, Morstyn G, Fox RM: Effect of peripheral-blood progenitor cells mobilised by filgrastim (G-CSF) on platelet recovery after high-dose chemotherapy. The Lancet 1992;339:640-644.

128 Moazzami K, Roohi A, Moazzami B: Granulocyte colony stimulating factor therapy for acute myocardial infarction. Cochrane Database Syst Rev 2013:CD008844.

$\checkmark 129$ Zohlnhofer D, Dibra A, Koppara T, Waha A de, Ripa RS, Kastrup J, Valgimigli M, Schomig A, Kastrati A: Stem cell mobilization by granulocyte colony-stimulating factor for myocardial recovery after acute myocardial infarction: A meta-analysis. J Am Coll Cardiol 2008;51:1429-1437.

130 Abdel-Latif A, Bolli R, Zuba-Surma EK, Tleyjeh IM, Hornung CA, Dawn B: Granulocyte colony-stimulating factor therapy for cardiac repair after acute myocardial infarction: A systematic review and meta-analysis of randomized controlled trials. Am Heart J 2008;156:216-226.e9.

131 Kang HJ, Kim HS, Zhang SY, Park KW, Cho HJ, Koo BK, Kim YJ, Lee DS, Sohn DW, Han KS, Oh BH, Lee MM, Park YB: Effects of intracoronary infusion of peripheral blood stem-cells mobilised with granulocyte-colony stimulating factor on left ventricular systolic function and restenosis after coronary stenting in myocardial infarction: The MAGIC cell randomised clinical trial. The Lancet 2004;363:751-756.

132 Kang HJ, Lee HY, Na SH, Chang SA, Park KW, Kim HK, Kim SY, Chang HJ, Lee W, Kang WJ, Koo BK, Kim YJ, Lee DS, Sohn DW, Han KS, Oh BH, Park YB, Kim HS: Differential effect of intracoronary infusion of mobilized peripheral blood stem cells by granulocyte colony-stimulating factor on left ventricular function and remodeling in patients with acute myocardial infarction versus old myocardial infarction: The MAGIC Cell3-DES randomized, controlled trial. Circulation 2006;114:I145-151.

133 Li ZQ, Zhang M, Jing YZ, Zhang WW, Liu Y, Cui LJ, Yuan L, Liu XZ, Yu X, Hu TS: The clinical study of autologous peripheral blood stem cell transplantation by intracoronary infusion in patients with acute myocardial infarction (AMI). Int J Cardiol 2007;115:52-56.

134 Tatsumi T, Ashihara E, Yasui T, Matsunaga S, Kido A, Sasada Y, Nishikawa S, Hadase M, Koide M, Nakamura R, Irie H, Ito K, Matsui A, Matsui H, Katamura M, Kusuoka S, Matoba S, Okayama S, Horii M, Uemura S, et al.: Intracoronary transplantation of non-expanded peripheral blood-derived mononuclear cells promotes improvement of cardiac function in patients with acute myocardial infarction. Circ J 2007;71:1199-1207.

135 Vrtovec B, Sever M, Jensterle M, Poglajen G, Janez A, Kravos N, Zemljic G, Cukjati M, Cernelc P, Haddad F, Wu JC, Jorde UP: Efficacy of CD34+ Stem Cell Therapy in Nonischemic Dilated Cardiomyopathy Is Absent in Patients With Diabetes but Preserved in Patients With Insulin Resistance. Stem Cells Transl Med 2016;5:632-638.

136 Lezaic L, Socan A, Poglajen G, Peitl PK, Sever M, Cukjati M, Cernelc P, Wu JC, Haddad F, Vrtovec B: Intracoronary transplantation of CD34(+) cells is associated with improved myocardial perfusion in patients with nonischemic dilated cardiomyopathy. J Card Fail 2015;21:145-152. 


\section{Cellular Physiology Cell Physiol Biochem 2018;48:2607-2655 \begin{tabular}{cl|l} 
DOI: 10.1159/000492704 & $\begin{array}{l}\text { O 2018 The Author(s). Published by S. Karger AG, Basel } \\
\text { www.karger.com/cpb }\end{array}$
\end{tabular} \\ Müller et al.: Cardiac Stem Cell Therapy}

137 Poglajen G, Sever M, Cukjati M, Cernelc P, Knezevic I, Zemljic G, Haddad F, Wu JC, Vrtovec B: Effects of transendocardial CD34+ cell transplantation in patients with ischemic cardiomyopathy. Circ Cardiovasc Interv 2014;7:552-559.

138 Losordo DW, Henry TD, Davidson C, Sup Lee J, Costa MA, Bass T, Mendelsohn F, Fortuin FD, Pepine CJ, Traverse JH, Amrani D, Ewenstein BM, Riedel N, Story K, Barker K, Povsic TJ, Harrington RA, Schatz RA: Intramyocardial, autologous CD34+ cell therapy for refractory angina. Circ Res 2011;109:428-436.

139 Losordo DW, Schatz RA, White CJ, Udelson JE, Veereshwarayya V, Durgin M, Poh KK, Weinstein R, Kearney M, Chaudhry M, Burg A, Eaton L, Heyd L, Thorne T, Shturman L, Hoffmeister P, Story K, Zak V, Dowling D, Traverse JH, et al.: Intramyocardial transplantation of autologous CD34+ stem cells for intractable angina: A phase I/IIa double-blind, randomized controlled trial. Circulation 2007;115:3165-3172.

140 Kawamoto A, Iwasaki H, Kusano K, Murayama T, Oyamada A, Silver M, Hulbert C, Gavin M, Hanley A, Ma H, Kearney M, Zak V, Asahara T, Losordo DW: CD34-positive cells exhibit increased potency and safety for therapeutic neovascularization after myocardial infarction compared with total mononuclear cells. Circulation 2006;114:2163-2169.

141 Vrtovec B, Poglajen G, Lezaic L, Sever M, Domanovic D, Cernelc P, Socan A, Schrepfer S, Torre-Amione G, Haddad F, Wu JC: Effects of intracoronary CD34+ stem cell transplantation in nonischemic dilated cardiomyopathy patients: 5-year follow-up. Circ Res 2013;112:165-173.

142 Vrtovec B, Poglajen G, Lezaic L, Sever M, Socan A, Domanovic D, Cernelc P, Torre-Amione G, Haddad F, $\mathrm{Wu}$ JC: Comparison of transendocardial and intracoronary CD34+ cell transplantation in patients with nonischemic dilated cardiomyopathy. Circulation 2013;128:S42-49.

143 Pasquet S, Sovalat H, Henon P, Bischoff N, Arkam Y, Ojeda-Uribe M, Le Bouar R, Rimelen V, Brink I, Dallemand R, Monassier JP: Long-term benefit of intracardiac delivery of autologous granulocyte-colonystimulating factor-mobilized blood CD34+ cells containing cardiac progenitors on regional heart structure and function after myocardial infarct. Cytotherapy 2009;11:1002-1015.

144 Lee Y, Chen Y-L, Sung PH, Ma MC, Pei SN, Wu CJ, Yang CH, Fu M, Ko SF, Leu S, Yip HK: Intracoronary Transfusion of Circulation-Derived CD34+ Cells Improves Left Ventricular Function in Patients With EndStage Diffuse Coronary Artery Disease Unsuitable for Coronary Intervention. Crit Care Med 2015;43:21172132.

145 Choi JH, Choi J, Lee WS, Rhee I, Lee SC, Gwon HC, Lee SH, Choe YH, Kim DW, Suh W, Kim DK, Jeon ES: Lack of additional benefit of intracoronary transplantation of autologous peripheral blood stem cell in patients with acute myocardial infarction. Circ J 2007;71:486-494.

146 Povsic TJ, Henry TD, Traverse JH, Fortuin FD, Schaer GL, Kereiakes DJ, Schatz RA, Zeiher AM, White CJ, Stewart DJ, Jolicoeur EM, Bass T, Henderson DA, Dignacco P, Gu Z, Al-Khalidi HR, Junge C, Nada A, Hunt AS, Losordo DW: The RENEW Trial: Efficacy and Safety of Intramyocardial Autologous CD34(+) Cell Administration in Patients With Refractory Angina. JACC Cardiovasc Interv 2016;9:1576-1585.

147 Samman Tahhan A, Hammadah M, Sandesara PB, Hayek SS, Kalogeropoulos AP, Alkhoder A, Mohamed Kelli H, Topel M, Ghasemzadeh N, Chivukula K, Ko YA, Aida H, Hesaroieh I, Mahar E, Kim JH, Wilson P, Shaw L, Vaccarino V, Waller EK, Quyyumi AA: Progenitor Cells and Clinical Outcomes in Patients With Heart Failure. Circ Heart Fail 2017;10.

148 Zuk PA, Zhu M, Ashjian P, Ugarte DA de, Huang JI, Mizuno H, Alfonso ZC, Fraser JK, Benhaim P, Hedrick MH: Human adipose tissue is a source of multipotent stem cells. Mol Biol Cell 2002;13:4279-4295.

149 Zuk PA, Zhu M, Mizuno H, Huang J, Futrell JW, Katz AJ, Benhaim P, Lorenz HP, Hedrick MH: Multilineage cells from human adipose tissue: Implications for cell-based therapies. Tissue Eng 2001;7:211-228.

150 Bourin P, Bunnell BA, Casteilla L, Dominici M, Katz AJ, March KL, Redl H, Rubin JP, Yoshimura K, Gimble JM: Stromal cells from the adipose tissue-derived stromal vascular fraction and culture expanded adipose tissue-derived stromal/stem cells: A joint statement of the International Federation for Adipose Therapeutics and Science (IFATS) and the International Society for Cellular Therapy (ISCT). Cytotherapy 2013;15:641-648.

151 Miyahara Y, Nagaya N, Kataoka M, Yanagawa B, Tanaka K, Hao H, Ishino K, Ishida H, Shimizu T, Kangawa K, Sano S, Okano T, Kitamura S, Mori H: Monolayered mesenchymal stem cells repair scarred myocardium after myocardial infarction. Nat Med 2006;12:459-465. 


\section{Cellular Physiology Cell Physiol Biochem 2018;48:2607-2655 \begin{tabular}{ll|l} 
and Biochemistry Publisned onIIne: 16 August, 2018 & $\begin{array}{l}\text { (c) } 2018 \text { The Author(s). Published by S. Karger AG, Basel } \\
\text { www.karger.com/cpb }\end{array}$ \\
\hline
\end{tabular} \\ Müller et al.: Cardiac Stem Cell Therapy}

152 Wang L, Deng J, Tian W, Xiang B, Yang T, Li G, Wang J, Gruwel M, Kashour T, Rendell J, Glogowski M, Tomanek B, Freed D, Deslauriers R, Arora RC, Tian G: Adipose-derived stem cells are an effective cell candidate for treatment of heart failure: An MR imaging study of rat hearts. Am J Physiol Heart Circ Physiol 2009;297:H1020-1031.

153 Chi C, Wang F, Xiang B, Deng J, Liu S, Lin H-Y, Natarajan K, Li G, Wang L, Wang J, Lin F, Freed DH, Arora RC, Liu H, Tian G: Adipose-derived stem cells from both visceral and subcutaneous fat deposits significantly improve contractile function of infarcted rat hearts. Cell Transplant 2015;24:2337-2351.

154 Bagno LLS, Werneck-de-Castro JPS, Oliveira PF, Cunha-Abreu MS, Rocha NN, Kasai-Brunswick TH, Lago VM, Goldenberg RCS, Campos-de-Carvalho AC: Adipose-derived stromal cell therapy improves cardiac function after coronary occlusion in rats. Cell Transplant 2012;21:1985-1996.

155 Gautam M, Fujita D, Kimura K, Ichikawa H, Izawa A, Hirose M, Kashihara T, Yamada M, Takahashi M, Ikeda U, Shiba Y: Transplantation of adipose tissue-derived stem cells improves cardiac contractile function and electrical stability in a rat myocardial infarction model. J Mol Cell Cardiol 2015;81:139-149.

156 Yang D, Wang W, Li L, Peng Y, Chen P, Huang H, Guo Y, Xia X, Wang Y, Wang H, Wang WE, Zeng C, Qin G: The Relative Contribution of Paracine Effect versus Direct Differentiation on Adipose-Derived Stem Cell Transplantation Mediated Cardiac Repair. PLoS One 2013;8:e59020.

157 Cai L, Johnstone BH, Cook TG, Tan J, Fishbein MC, Chen -S, March KL: IFATS collection: Human adipose tissue-derived stem cells induce angiogenesis and nerve sprouting following myocardial infarction, in conjunction with potent preservation of cardiac function. Stem Cells 2009;27:230-237.

158 Hong SJ, Rogers PI, Kihlken J, Warfel J, Bull C, Deuter-Reinhard M, Feng D, Xie J, Kyle A, Merfeld-Clauss S, Johnstone BH, Traktuev DO, Chen PS, Lindner JR, March KL: Intravenous xenogeneic transplantation of human adipose-derived stem cells improves left ventricular function and microvascular integrity in swine myocardial infarction model. Catheter Cardiovasc Interv 2015;86:E38-E48.

159 Mazo M, Hernandez S, Gavira JJ, Abizanda G, Arana M, Lopez-Martinez T, Moreno C, Merino J, MartinoRodriguez A, Uixeira A, Garcia de Jalon JA, Pastrana J, Martinez-Caro D, Prosper F: Treatment of reperfused ischemia with adipose-derived stem cells in a preclinical Swine model of myocardial infarction. Cell Transplant 2012;21:2723-2733.

160 Arana M, Gavira JJ, Pena E, Gonzalez A, Abizanda G, Cilla M, Perez MM, Albiasu E, Aguado N, Casado M, Lopez B, Gonzalez S, Soriano M, Moreno C, Merino J, Garcia-Verdugo JM, Diez J, Doblare M, Pelacho B, Prosper F: Epicardial delivery of collagen patches with adipose-derived stem cells in rat and minipig models of chronic myocardial infarction. Biomaterials 2014;35:143-151.

161 Yu LH, Kim MH, Park TH, Cha KS, Kim YD, Quan ML, Rho MS, Seo SY, Jung JS: Improvement of cardiac function and remodeling by transplanting adipose tissue-derived stromal cells into a mouse model of acute myocardial infarction. Int J Cardiol 2010;139:166-172.

162 Schenke-Layland K, Strem BM, Jordan MC, Deemedio MT, Hedrick MH, Roos KP, Fraser JK, MacLellan WR: Adipose tissue-derived cells improve cardiac function following myocardial infarction. J Surg Res 2009;153:217-223.

163 Valina C, Pinkernell K, Song Y-H, Bai X, Sadat S, Campeau RJ, Le Jemtel TH, Alt E: Intracoronary administration of autologous adipose tissue-derived stem cells improves left ventricular function, perfusion, and remodelling after acute myocardial infarction. Eur Heart J 2007;28:2667-2677.

164 Kim JH, Joo HJ, Kim M, Choi SC, Lee JI, Hong SJ, Lim DS: Transplantation of Adipose-Derived Stem Cell Sheet Attenuates Adverse Cardiac Remodeling in Acute Myocardial Infarction. Tissue Eng Part A 2017;23:1-11.

165 Houtgraaf JH, den Dekker WK, van Dalen BM, Springeling T, Jong R de, van Geuns RJ, Geleijnse ML, Fernandez-Aviles F, Zijlsta F, Serruys PW, Duckers HJ: First experience in humans using adipose tissuederived regenerative cells in the treatment of patients with ST-segment elevation myocardial infarction. J Am Coll Cardiol 2012;59:539-540.

166 Yoshimura K, Shigeura T, Matsumoto D, Sato T, Takaki Y, Aiba-Kojima E, Sato K, Inoue K, Nagase T, Koshima I, Gonda K: Characterization of freshly isolated and cultured cells derived from the fatty and fluid portions of liposuction aspirates. J Cell Physiol 2006;208:64-76.

167 Perin EC, Sanz-Ruiz R, Sanchez PL, Lasso J, Perez-Cano R, Alonso-Farto JC, Perez-David E, Fernandez-Santos ME, Serruys PW, Duckers HJ, Kastrup J, Chamuleau S, Zheng Y, Silva GV, Willerson JT, Fernandez-Aviles F: Adipose-derived regenerative cells in patients with ischemic cardiomyopathy: The PRECISE Trial. Am Heart J 2014;168:88-95.e2. 


\section{Cellular Physiology Cell Physiol Biochem 2018;48:2607-2655 \begin{tabular}{ll|l} 
and Biochemistry Publisned onIIne: 16 August, 2018 & $\begin{array}{l}\text { (c) } 2018 \text { The Author(s). Published by S. Karger AG, Basel } \\
\text { www.karger.com/cpb }\end{array}$ \\
\hline
\end{tabular} \\ Müller et al.: Cardiac Stem Cell Therapy}

168 Henry TD, Pepine CJ, Lambert CR, Traverse JH, Schatz R, Costa M, Povsic TJ, David Anderson R, Willerson JT, Kesten S, Perin EC: The Athena trials: Autologous adipose-derived regenerative cells for refractory chronic myocardial ischemia with left ventricular dysfunction. Catheter Cardiovasc Interv 2017;89:169-177.

169 Comella K, Parcero J, Bansal H, Perez J, Lopez J, Agrawal A, Ichim T: Effects of the intramyocardial implantation of stromal vascular fraction in patients with chronic ischemic cardiomyopathy. J Transl Med 2016;14:158.

170 Bergmann 0, Bhardwaj RD, Bernard S, Zdunek S, Barnabe-Heider F, Walsh S, Zupicich J, Alkass K, Buchholz BA, Druid H, Jovinge S, Frisen J: Evidence for cardiomyocyte renewal in humans. Science 2009;324:98-102.

171 Kajstura J, Urbanek K, Perl S, Hosoda T, Zheng H, Ogorek B, Ferreira-Martins J, Goichberg P, Rondon-Clavo C, Sanada F, D’Amario D, Rota M, Del Monte F, Orlic D, Tisdale J, Leri A, Anversa P: Cardiomyogenesis in the adult human heart. Circ Res 2010;107:305-315.

172 Beltrami AP, Barlucchi L, Torella D, Baker M, Limana F, Chimenti S, Kasahara H, Rota M, Musso E, Urbanek K, Leri A, Kajstura J, Nadal-Ginard B, Anversa P: Adult cardiac stem cells are multipotent and support myocardial regeneration. Cell 2003;114:763-776.

173 Bearzi C, Rota M, Hosoda T, Tillmanns J, Nascimbene A, de ngelis A, Yasuzawa-Amano S, Trofimova I, Siggins RW, Lecapitaine N, Cascapera S, Beltrami AP, D’Alessandro DA, Zias E, Quaini F, Urbanek K, Michler RE, Bolli R, Kajstura J, Leri A, et al.: Human cardiac stem cells. Proc Natl Acad Sci U S A 2007;104:14068-14073.

174 Ellison GM, Vicinanza C, Smith AJ, Aquila I, Leone A, Waring CD, Henning BJ, Stirparo GG, Papait R, Scarfo M, Agosti V, Viglietto G, Condorelli G, Indolfi C, Ottolenghi S, Torella D, Nadal-Ginard B: Adult c-kit(pos) cardiac stem cells are necessary and sufficient for functional cardiac regeneration and repair. Cell 2013;154:827842.

175 Chimenti I, Smith RR, Li T-S, Gerstenblith G, Messina E, Giacomello A, Marban E: Relative roles of direct regeneration versus paracrine effects of human cardiosphere-derived cells transplanted into infarcted mice. Circ Res 2010;106:971-980.

176 Malliaras K, Li T-S, Luthringer D, Terrovitis J, Cheng K, Chakravarty T, Galang G, Zhang Y, Schoenhoff F, van Eyk J, Marban L, Marban E: Safety and efficacy of allogeneic cell therapy in infarcted rats transplanted with mismatched cardiosphere-derived cells. Circulation 2012;125:100-112.

177 White AJ, Smith RR, Matsushita S, Chakravarty T, Czer LSC, Burton K, Schwarz ER, Davis DR, Wang Q, Reinsmoen NL, Forrester JS, Marban E, Makkar R: Intrinsic cardiac origin of human cardiosphere-derived cells. Eur Heart J 2013;34:68-75.

178 Messina E, Angelis L de, Frati G, Morrone S, Chimenti S, Fiordaliso F, Salio M, Battaglia M, Latronico MVG, Coletta M, Vivarelli E, Frati L, Cossu G, Giacomello A: Isolation and expansion of adult cardiac stem cells from human and murine heart. Circ Res 2004;95:911-921.

179 Uchida S, Gaspari P de, Kostin S, Jenniches K, Kilic A, Izumiya Y, Shiojima I, Grosse Kreymborg K, Renz H, Walsh K, Braun T: Sca1-derived cells are a source of myocardial renewal in the murine adult heart. Stem Cell Reports 2013;1:397-410.

180 Wang X, Hu Q, Nakamura Y, Lee J, Zhang G, From AHL, Zhang J: The role of the sca-1+/CD31- cardiac progenitor cell population in postinfarction left ventricular remodeling. Stem Cells 2006;24:1779-1788.

181 Oh H, Bradfute SB, Gallardo TD, Nakamura T, Gaussin V, Mishina Y, Pocius J, Michael LH, Behringer RR, Garry DJ, Entman ML, Schneider MD: Cardiac progenitor cells from adult myocardium: Homing, differentiation, and fusion after infarction. Proc Natl Acad Sci U S A 2003;100:12313-12318.

182 Laugwitz KL, Moretti A, Lam J, Gruber P, Chen Y, Woodard S, Lin LZ, Cai CL, Lu MM, Reth M, Platoshyn O, Yuan JX, Evans S, Chien KR: Postnatal isl1+ cardioblasts enter fully differentiated cardiomyocyte lineages. Nature 2005;433:647-653.

183 Genead R, Danielsson C, Andersson AB, Corbascio M, Franco-Cereceda A, Sylven C, Grinnemo KH: Islet-1 cells are cardiac progenitors present during the entire lifespan: From the embryonic stage to adulthood. Stem Cells Dev 2010;19:1601-1615.

184 Cai CL, Liang X, Shi Y, Chu PH, Pfaff SL, Chen J, Evans S: Isl1 identifies a cardiac progenitor population that proliferates prior to differentiation and contributes a majority of cells to the heart. Dev Cell 2003;5:877889.

185 Pfister O, Mouquet F, Jain M, Summer R, Helmes M, Fine A, Colucci WS, Liao R: CD31- but Not CD31+ cardiac side population cells exhibit functional cardiomyogenic differentiation. Circ Res 2005;97:52-61. 


\section{Cellular Physiology Cell Physiol Biochem 2018;48:2607-2655 \begin{tabular}{ll|l} 
and Biochemistry Published OnIIne: 16 August, 2018 & $\begin{array}{l}\text { (c) } 2018 \text { The Author(s). Published by S. Karger AG, Basel } \\
\text { www.karger.com/cpb }\end{array}$ \\
\hline
\end{tabular}

186 Martin CM, Meeson AP, Robertson SM, Hawke TJ, Richardson JA, Bates S, Goetsch SC, Gallardo TD, Garry DJ: Persistent expression of the ATP-binding cassette transporter, Abcg2, identifies cardiac SP cells in the developing and adult heart. Dev Biol 2004;265:262-275.

187 Oyama T, Nagai T, Wada H, Naito AT, Matsuura K, Iwanaga K, Takahashi T, Goto M, Mikami Y, Yasuda N, Akazawa H, Uezumi A, Takeda S'i, Komuro I: Cardiac side population cells have a potential to migrate and differentiate into cardiomyocytes in vitro and in vivo. J Cell Biol 2007;176:329-341.

188 Hsieh PCH, Segers VFM, Davis ME, MacGillivray C, Gannon J, Molkentin JD, Robbins J, Lee RT: Evidence from a genetic fate-mapping study that stem cells refresh adult mammalian cardiomyocytes after injury. Nat Med 2007;13:970-974.

189 Malliaras K, Zhang Y, Seinfeld J, Galang G, Tseliou E, Cheng K, Sun B, Aminzadeh M, Marban E: Cardiomyocyte proliferation and progenitor cell recruitment underlie therapeutic regeneration after myocardial infarction in the adult mouse heart. EMBO Mol Med 2013;5:191-209.

190 Senyo SE, Steinhauser ML, Pizzimenti CL, Yang VK, Cai L, Wang M, Wu TD, Guerquin-Kern JL, Lechene CP, Lee RT: Mammalian heart renewal by pre-existing cardiomyocytes. Nature 2013;493:433-436.

191 Zwetsloot PP, Vegh AMD, Jansen Of Lorkeers SJ, van Hout GPJ, Currie GL, Sena ES, Gremmels H, Buikema JW, Goumans MJ, Macleod MR, Doevendans PA, Chamuleau SAJ, Sluijter JPG: Cardiac Stem Cell Treatment in Myocardial Infarction: A Systematic Review and Meta-Analysis of Preclinical Studies. Circ Res 2016;118:1223-1232.

192 Bolli R, Chugh AR, D’Amario D, Loughran JH, Stoddard MF, Ikram S, Beache GM, Wagner SG, Leri A, Hosoda T, Sanada F, Elmore JB, Goichberg P, Cappetta D, Solankhi NK, Fahsah I, Rokosh DG, Slaughter MS, Kajstura J, Anversa P: Cardiac stem cells in patients with ischaemic cardiomyopathy (SCIPIO): Initial results of a randomised phase 1 trial. The Lancet 2011;378:1847-1857.

193 Chugh AR, Beache GM, Loughran JH, Mewton N, Elmore JB, Kajstura J, Pappas P, Tatooles A, Stoddard MF, Lima JAC, Slaughter MS, Anversa P, Bolli R: Administration of cardiac stem cells in patients with ischemic cardiomyopathy: The SCIPIO trial: surgical aspects and interim analysis of myocardial function and viability by magnetic resonance. Circulation 2012;126:S54-64.

194 Makkar RR, Smith RR, Cheng K, Malliaras K, Thomson LEJ, Berman D, Czer LSC, Marbán L, Mendizabal A, Johnston PV, Russell SD, Schuleri KH, Lardo AC, Gerstenblith G, Marbán E: Intracoronary cardiospherederived cells for heart regeneration after myocardial infarction (CADUCEUS): A prospective, randomised phase 1 trial. The Lancet 2012;379:895-904.

195 Malliaras K, Makkar RR, Smith RR, Cheng K, Wu E, Bonow RO, Marban L, Mendizabal A, Cingolani E, Johnston PV, Gerstenblith G, Schuleri KH, Lardo AC, Marban E: Intracoronary cardiosphere-derived cells after myocardial infarction: Evidence of therapeutic regeneration in the final 1-year results of the CADUCEUS trial (CArdiosphere-Derived aUtologous stem CElls to reverse ventricUlar dySfunction). J Am Coll Cardiol 2014;63:110-122.

196 Ishigami S, Ohtsuki S, Eitoku T, Ousaka D, Kondo M, Kurita Y, Hirai K, Fukushima Y, Baba K, Goto T, Horio N, Kobayashi J, Kuroko Y, Kotani Y, Arai S, Iwasaki T, Sato S, Kasahara S, Sano S, Oh H: Intracoronary Cardiac Progenitor Cells in Single Ventricle Physiology: The PERSEUS (Cardiac Progenitor Cell Infusion to Treat Univentricular Heart Disease) Randomized Phase 2 Trial. Circ Res 2017;120:1162-1173.

197 Thomson JA: Embryonic Stem Cell Lines Derived from Human Blastocysts. Science 1998;282:1145-1147.

198 Talkhabi M, Aghdami N, Baharvand H: Human cardiomyocyte generation from pluripotent stem cells: A state-of-art. Life Sci 2016;145:98-113.

199 Veerman CC, Kosmidis G, Mummery CL, Casini S, Verkerk AO, Bellin M: Immaturity of human stem-cellderived cardiomyocytes in culture: fatal flaw or soluble problem? Stem Cells Dev 2015;24:1035-1052.

200 Min JY, Yang Y, Converso KL, Liu L, Huang Q, Morgan JP, Xiao YF: Transplantation of embryonic stem cells improves cardiac function in postinfarcted rats. J Appl Physiol (1985) 2002;92:288-296.

201 Behfar A, Zingman LV, Hodgson DM, Rauzier JM, Kane GC, Terzic A, Puceat M: Stem cell differentiation requires a paracrine pathway in the heart. FASEB J 2002;16:1558-1566.

202 Nussbaum J, Minami E, Laflamme MA, Virag JAI, Ware CB, Masino A, Muskheli V, Pabon L, Reinecke H, Murry CE: Transplantation of undifferentiated murine embryonic stem cells in the heart: teratoma formation and immune response. FASEB J 2007;21:1345-1357.

203 Caspi O, Huber I, Kehat I, Habib M, Arbel G, Gepstein A, Yankelson L, Aronson D, Beyar R, Gepstein L: Transplantation of human embryonic stem cell-derived cardiomyocytes improves myocardial performance in infarcted rat hearts. J Am Coll Cardiol 2007;50:1884-1893. 


\section{Cellular Physiology Cell Physiol Biochem 2018;48:2607-2655 \begin{tabular}{ll|l} 
and Biochemistry Publisnea onine: 10 August, 2018 & $\begin{array}{l}\text { (c) } 2018 \text { The Author(s). Published by S. Karger AG, Basel } \\
\text { www.karger.com/cpb }\end{array}$ \\
\hline
\end{tabular} \\ Müller et al.: Cardiac Stem Cell Therapy}

204 Blin G, Nury D, Stefanovic S, Neri T, Guillevic O, Brinon B, Bellamy V, Rucker-Martin C, Barbry P, Bel A, Bruneval P, Cowan C, Pouly J, Mitalipov S, Gouadon E, Binder P, Hagege A, Desnos M, Renaud JF, Menasche P, et al.: A purified population of multipotent cardiovascular progenitors derived from primate pluripotent stem cells engrafts in postmyocardial infarcted nonhuman primates. J Clin Invest 2010;120:1125-1139.

205 Shiba Y, Fernandes S, Zhu WZ, Filice D, Muskheli V, Kim J, Palpant NJ, Gantz J, Moyes KW, Reinecke H, van Biber B, Dardas T, Mignone JL, Izawa A, Hanna R, Viswanathan M, Gold JD, Kotlikoff MI, Sarvazyan N, Kay MW, et al.: Human ES-cell-derived cardiomyocytes electrically couple and suppress arrhythmias in injured hearts. Nature 2012;489:322-325.

206 Laflamme MA, Chen KY, Naumova AV, Muskheli V, Fugate JA, Dupras SK, Reinecke H, Xu C, Hassanipour M, Police S, O’Sullivan C, Collins L, Chen Y, Minami E, Gill EA, Ueno S, Yuan C, Gold J, Murry CE: Cardiomyocytes derived from human embryonic stem cells in pro-survival factors enhance function of infarcted rat hearts. Nat Biotechnol 2007;25:1015-1024.

207 van Laake LW, Passier R, Monshouwer-Kloots J, Verkleij AJ, Lips DJ, Freund C, den Ouden K, Ward-van Oostwaard D, Korving J, Tertoolen LG, van Echteld CJ, Doevendans PA, Mummery CL: Human embryonic stem cell-derived cardiomyocytes survive and mature in the mouse heart and transiently improve function after myocardial infarction. Stem Cell Res 2007;1:9-24.

208 Laflamme MA, Gold J, Xu C, Hassanipour M, Rosler E, Police S, Muskheli V, Murry CE: Formation of Human Myocardium in the Rat Heart from Human Embryonic Stem Cells. The American Journal of Pathology 2005;167:663-671.

209 Yeghiazarians Y, Gaur M, Zhang Y, Sievers RE, Ritner C, Prasad M, Boyle A, Bernstein HS: Myocardial improvement with human embryonic stem cell-derived cardiomyocytes enriched by p38MAPK inhibition. Cytotherapy 2012;14:223-231.

-210 Tomescot A, Leschik J, Bellamy V, Dubois G, Messas E, Bruneval P, Desnos M, Hagege AA, Amit M, Itskovitz J, Menasche P, Puceat M: Differentiation in vivo of cardiac committed human embryonic stem cells in postmyocardial infarcted rats. Stem Cells 2007;25:2200-2205.

-211 Chong JJH, Yang X, Don CW, Minami E, Liu YW, Weyers JJ, Mahoney WM, van Biber B, Cook SM, Palpant NJ, Gantz JA, Fugate JA, Muskheli V, Gough GM, Vogel KW, Astley CA, Hotchkiss CE, Baldessari A, Pabon L, Reinecke $\mathrm{H}$, et al.: Human embryonic-stem-cell-derived cardiomyocytes regenerate non-human primate hearts. Nature 2014;510:273-177.

212 Ménard C, Hagège AA, Agbulut O, Barro M, Morichetti MC, Brasselet C, Bel A, Messas E, Bissery A, Bruneval $\mathrm{P}$, Desnos M, Pucéat M, Menasché P: Transplantation of cardiac-committed mouse embryonic stem cells to infarcted sheep myocardium: A preclinical study. The Lancet 2005;366:1005-1012.

213 Menasché P, Vanneaux V, Fabreguettes JR, Bel A, Tosca L, Garcia S, Bellamy V, Farouz Y, Pouly J, Damour $\mathrm{O}$, Périer MC, Desnos M, Hagège $\mathrm{A}$, Agbulut $\mathrm{O}$, Bruneval $\mathrm{P}$, Tachdjian $\mathrm{G}$, Trouvin JH, Larghero J: Towards a clinical use of human embryonic stem cell-derived cardiac progenitors: a translational experience. Eur Heart J 2015;36:743-750.

214 Menasche P, Vanneaux V, Hagege A, Bel A, Cholley B, Cacciapuoti I, Parouchev A, Benhamouda N, Tachdjian G, Tosca L, Trouvin JH, Fabreguettes JR, Bellamy V, Guillemain R, Suberbielle Boissel C, Tartour E, Desnos M, Larghero J: Human embryonic stem cell-derived cardiac progenitors for severe heart failure treatment: first clinical case report. Eur Heart J 2015;36:2011-2017.

215 Robertson JA: Human embryonic stem cell research: ethical and legal issues. Nat Rev Genet 2001;2:74-78.

-216 Swijnenburg RJ, Tanaka M, Vogel H, Baker J, Kofidis T, Gunawan F, Lebl DR, Caffarelli AD, Bruin JL de, Fedoseyeva EV, Robbins RC: Embryonic stem cell immunogenicity increases upon differentiation after transplantation into ischemic myocardium. Circulation 2005;112:I166-172.

217 Nouspikel T: Genetic instability in human embryonic stem cells: prospects and caveats. Future Oncol 2013;9:867-877.

218 Ilic D, Ogilvie C: Concise Review: Human Embryonic Stem Cells-What Have We Done? What Are We Doing? Where Are We Going? Stem Cells 2017;35:17-25.

219 Martin U: Genome stability of programmed stem cell products. Adv Drug Deliv Rev 2017;120:108-117.

220 Takahashi K, Yamanaka S: Induction of pluripotent stem cells from mouse embryonic and adult fibroblast cultures by defined factors. Cell 2006;126:663-676.

221 Takahashi K, Tanabe K, Ohnuki M, Narita M, Ichisaka T, Tomoda K, Yamanaka S: Induction of pluripotent stem cells from adult human fibroblasts by defined factors. Cell 2007;131:861-872. 


\section{Cellular Physiology Cell Physiol Biochem 2018;48:2607-2655

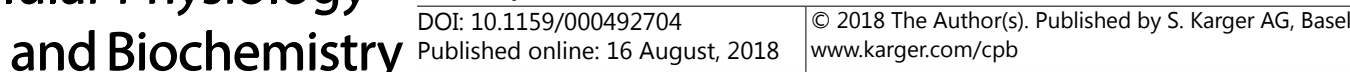 \\ Müller et al.: Cardiac Stem Cell Therapy}

222 Narazaki G, Uosaki H, Teranishi M, Okita K, Kim B, Matsuoka S, Yamanaka S, Yamashita JK: Directed and systematic differentiation of cardiovascular cells from mouse induced pluripotent stem cells. Circulation 2008;118:498-506.

223 Mauritz C, Schwanke K, Reppel M, Neef S, Katsirntaki K, Maier LS, Nguemo F, Menke S, Haustein M, Hescheler J, Hasenfuss G, Martin U: Generation of functional murine cardiac myocytes from induced pluripotent stem cells. Circulation 2008;118:507-517.

224 Kuzmenkin A, Liang H, Xu G, Pfannkuche K, Eichhorn H, Fatima A, Luo H, Saric T, Wernig M, Jaenisch R, Hescheler J: Functional characterization of cardiomyocytes derived from murine induced pluripotent stem cells in vitro. FASEB J 2009;23:4168-4180.

-225 Zhang J, Wilson GF, Soerens AG, Koonce CH, Yu J, Palecek SP, Thomson JA, Kamp TJ: Functional cardiomyocytes derived from human induced pluripotent stem cells. Circ Res 2009;104:e30-41.

226 Ma J, Guo L, Fiene SJ, Anson BD, Thomson JA, Kamp TJ, Kolaja KL, Swanson BJ, January CT: High purity human-induced pluripotent stem cell-derived cardiomyocytes: electrophysiological properties of action potentials and ionic currents. Am J Physiol Heart Circ Physiol 2011;301:H2006-2017.

227 Zwi L, Caspi O, Arbel G, Huber I, Gepstein A, Park IH, Gepstein L: Cardiomyocyte differentiation of human induced pluripotent stem cells. Circulation 2009;120:1513-1523.

228 Burridge PW, Zambidis ET: Highly efficient directed differentiation of human induced pluripotent stem cells into cardiomyocytes. Methods Mol Biol 2013;997:149-161.

229 Kong CW, Akar FG, Li RA: Translational potential of human embryonic and induced pluripotent stem cells for myocardial repair: insights from experimental models. Thromb Haemost 2010;104:30-38.

230 Poon E, Kong CW, Li RA: Human pluripotent stem cell-based approaches for myocardial repair: from the electrophysiological perspective. Mol Pharm 2011;8:1495-1504.

231 Yang X, Pabon L, Murry CE: Engineering adolescence: maturation of human pluripotent stem cell-derived cardiomyocytes. Circ Res 2014;114:511-523.

232 Hartman ME, Dai DF, Laflamme MA: Human pluripotent stem cells: Prospects and challenges as a source of cardiomyocytes for in vitro modeling and cell-based cardiac repair. Adv Drug Deliv Rev 2016;96:3-17.

233 Barbuti A, Benzoni P, Campostrini G, Dell'Era P: Human derived cardiomyocytes: A decade of knowledge after the discovery of induced pluripotent stem cells. Dev Dyn 2016;245:1145-1158.

234 Kawamura M, Miyagawa S, Miki K, Saito A, Fukushima S, Higuchi T, Kawamura T, Kuratani T, Daimon T, Shimizu T, Okano T, Sawa Y: Feasibility, safety, and therapeutic efficacy of human induced pluripotent stem cell-derived cardiomyocyte sheets in a porcine ischemic cardiomyopathy model. Circulation 2012;126:S2937.

235 Citro L, Naidu S, Hassan F, Kuppusamy ML, Kuppusamy P, Angelos MG, Khan M: Comparison of human induced pluripotent stem-cell derived cardiomyocytes with human mesenchymal stem cells following acute myocardial infarction. PLoS One 2014;9:e116281.

-236 Zhang L, Guo J, Zhang P, Xiong Q Wu SC, Xia L, Roy SS, Tolar J, O’Connell TD, Kyba M, Liao K, Zhang J: Derivation and high engraftment of patient-specific cardiomyocyte sheet using induced pluripotent stem cells generated from adult cardiac fibroblast. Circ Heart Fail 2015;8:156-166.

-237 Ye L, Chang YH, Xiong Q, Zhang P, Zhang L, Somasundaram P, Lepley M, Swingen C, Su L, Wendel JS, Guo J, Jang A, Rosenbush D, Greder L, Dutton JR, Zhang J, Kamp TJ, Kaufman DS, Ge Y, Zhang J: Cardiac repair in a porcine model of acute myocardial infarction with human induced pluripotent stem cell-derived cardiovascular cells. Cell Stem Cell 2014;15:750-761.

238 Carpenter L, Carr C, Yang CT, Stuckey DJ, Clarke K, Watt SM: Efficient differentiation of human induced pluripotent stem cells generates cardiac cells that provide protection following myocardial infarction in the rat. Stem Cells Dev 2012;21:977-986.

239 Mauritz C, Martens A, Rojas SV, Schnick T, Rathert C, Schecker N, Menke S, Glage S, Zweigerdt R, Haverich A, Martin U, Kutschka I: Induced pluripotent stem cell (iPSC)-derived Flk-1 progenitor cells engraft, differentiate, and improve heart function in a mouse model of acute myocardial infarction. Eur Heart J 2011;32:2634-2641.

240 Martens A, Kensah G, Rojas S, Rotärmel A, Baraki H, Haverich A, Martin U, Gruh I, Kutschka I: Induced pluripotent stem cell (iPSC)-derived cardiomyocytes engraft and improve heart function in a mouse model of acute myocardial infarction. Thorac cardiovasc Surg 2012;60. 


\section{Cellular Physiology Cell Physiol Biochem 2018;48:2607-2655 \begin{tabular}{ll|l} 
and Biochemistry Publisned onIIne: 16 August, 2018 & $\begin{array}{l}\text { (c) } 2018 \text { The Author(s). Published by S. Karger AG, Basel } \\
\text { www.karger.com/cpb }\end{array}$ \\
\hline
\end{tabular} \\ Müller et al.: Cardiac Stem Cell Therapy}

241 Yu J, Vodyanik MA, Smuga-Otto K, Antosiewicz-Bourget J, Frane JL, Tian S, Nie J, Jonsdottir GA, Ruotti V, Stewart R, Slukvin II, Thomson JA: Induced pluripotent stem cell lines derived from human somatic cells. Science 2007;318:1917-1920.

242 Yoshihara M, Hayashizaki Y, Murakawa Y: Genomic Instability of iPSCs: Challenges Towards Their Clinical Applications. Stem Cell Rev 2016.

243 Liu X, Li W, Fu X, Xu Y: The Immunogenicity and Immune Tolerance of Pluripotent Stem Cell Derivatives. Front Immunol 2017;8:645.

244 Kaneko S, Yamanaka S: To be immunogenic, or not to be: that's the iPSC question. Cell Stem Cell 2013;12:385-386.

-245 Stadtfeld M, Nagaya M, Utikal J, Weir G, Hochedlinger K: Induced pluripotent stem cells generated without viral integration. Science 2008;322:945-949.

-246 Zhou W, Freed CR: Adenoviral gene delivery can reprogram human fibroblasts to induced pluripotent stem cells. Stem Cells 2009;27:2667-2674.

247 Fusaki N, Ban H, Nishiyama A, Saeki K, Hasegawa M: Efficient induction of transgene-free human pluripotent stem cells using a vector based on Sendai virus, an RNA virus that does not integrate into the host genome. Proc Jpn Acad Ser B Phys Biol Sci 2009;85:348-362.

248 Yu J, Hu K, Smuga-Otto K, Tian S, Stewart R, Slukvin II, Thomson JA: Human induced pluripotent stem cells free of vector and transgene sequences. Science 2009;324:797-801.

249 Woltjen K, Michael IP, Mohseni P, Desai R, Mileikovsky M, Hämäläinen R, Cowling R, Wang W, Liu P, Gertsenstein M, Kaji K, Sung HK, Nagy A: piggyBac transposition reprograms fibroblasts to induced pluripotent stem cells. Nature 2009;458:766-770.

250 Kaji K, Norrby K, Paca A, Mileikovsky M, Mohseni P, Woltjen K: Virus-free induction of pluripotency and subsequent excision of reprogramming factors. Nature 2009;458:771-775.

251 Kim D, Kim CH, Moon JI, Chung YG, Chang MY, Han BS, Ko S, Yang E, Cha KY, Lanza R, Kim KS: Generation of human induced pluripotent stem cells by direct delivery of reprogramming proteins. Cell Stem Cell 2009;4:472-476.

252 Zhou H, Wu S, Joo JY, Zhu S, Han DW, Lin T, Trauger S, Bien G, Yao S, Zhu Y, Siuzdak G, Scholer HR, Duan L, Ding S: Generation of induced pluripotent stem cells using recombinant proteins. Cell Stem Cell 2009;4:381-384.

253 Warren L, Manos PD, Ahfeldt T, Loh YH, Li H, Lau F, Ebina W, Mandal PK, Smith ZD, Meissner A, Daley GQ Brack AS, Collins JJ, Cowan C, Schlaeger TM, Rossi DJ: Highly efficient reprogramming to pluripotency and directed differentiation of human cells with synthetic modified mRNA. Cell Stem Cell 2010;7:618-630.

254 Miyoshi N, Ishii H, Nagano H, Haraguchi N, Dewi DL, Kano Y, Nishikawa S, Tanemura M, Mimori K, Tanaka F, Saito T, Nishimura J, Takemasa I, Mizushima T, Ikeda M, Yamamoto H, Sekimoto M, Doki Y, Mori M: Reprogramming of mouse and human cells to pluripotency using mature microRNAs. Cell Stem Cell 2011;8:633-638.

255 Anokye-Danso F, Trivedi CM, Juhr D, Gupta M, Cui Z, Tian Y, Zhang Y, Yang W, Gruber PJ, Epstein JA, Morrisey EE: Highly efficient miRNA-mediated reprogramming of mouse and human somatic cells to pluripotency. Cell Stem Cell 2011;8:376-388.

256 Hou P, Li Y, Zhang X, Liu C, Guan J, Li H, Zhao T, Ye J, Yang W, Liu K, Ge J, Xu J, Zhang Q, Zhao Y, Deng $\mathrm{H}$ : Pluripotent stem cells induced from mouse somatic cells by small-molecule compounds. Science 2013;341:651-654.

257 Kang PJ, Moon JH, Yoon BS, Hyeon S, Jun EK, Park G, Yun W, Park J, Park M, Kim A, Whang KY, Koh GY, Oh S, You S: Reprogramming of mouse somatic cells into pluripotent stem-like cells using a combination of small molecules. Biomaterials 2014;35:7336-7345.

258 Zhao Y, Zhao T, Guan J, Zhang X, Fu Y, Ye J, Zhu J, Meng G, Ge J, Yang S, Cheng L, Du Y, Zhao C, Wang T, Su L, Yang W, Deng H: A XEN-like State Bridges Somatic Cells to Pluripotency during Chemical Reprogramming. Cell 2015;163:1678-1691.

259 Yu H, Lu K, Zhu J, Wang J: Stem cell therapy for ischemic heart diseases. Br Med Bull 2017;121:135-154.

260 Gnecchi M, Zhang Z, Ni A, Dzau VJ: Paracrine mechanisms in adult stem cell signaling and therapy. Circ Res 2008;103:1204-1219.

261 Menasché P, Vanneaux V: Stem cells for the treatment of heart failure. Curr Res Transl Med 2016;64:97106. 


\section{Cellular Physiology Cell Physiol Biochem 2018;48:2607-2655

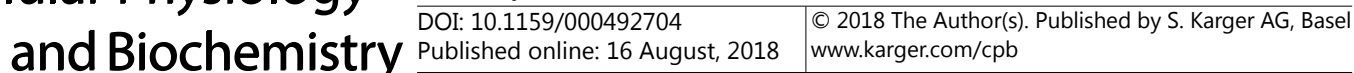 \\ Müller et al.: Cardiac Stem Cell Therapy}

262 Toma C, Pittenger MF, Cahill KS, Byrne BJ, Kessler PD: Human mesenchymal stem cells differentiate to a cardiomyocyte phenotype in the adult murine heart. Circulation 2002;105:93-98.

-263 Rota M, Kajstura J, Hosoda T, Bearzi C, Vitale S, Esposito G, Iaffaldano G, Padin-Iruegas ME, Gonzalez A, Rizzi R, Small N, Muraski J, Alvarez R, Chen X, Urbanek K, Bolli R, Houser SR, Leri A, Sussman MA, Anversa P: Bone marrow cells adopt the cardiomyogenic fate in vivo. Proc Natl Acad Sci U S A 2007;104:17783-17788.

264 Kajstura J, Rota M, Whang B, Cascapera S, Hosoda T, Bearzi C, Nurzynska D, Kasahara H, Zias E, Bonafe M, Nadal-Ginard B, Torella D, Nascimbene A, Quaini F, Urbanek K, Leri A, Anversa P: Bone marrow cells differentiate in cardiac cell lineages after infarction independently of cell fusion. Circ Res 2005;96:127-137.

265 Murasawa S, Kawamoto A, Horii M, Nakamori S, Asahara T: Niche-dependent translineage commitment of endothelial progenitor cells, not cell fusion in general, into myocardial lineage cells. Arterioscler Thromb Vasc Biol 2005;25:1388-1394.

266 Yoon Y-s, Wecker A, Heyd L, Park JS, Tkebuchava T, Kusano K, Hanley A, Scadova H, Qin G, Cha DH, Johnson KL, Aikawa R, Asahara T, Losordo DW: Clonally expanded novel multipotent stem cells from human bone marrow regenerate myocardium after myocardial infarction. J Clin Invest 2005;115:326-338.

-267 Quevedo HC, Hatzistergos KE, Oskouei BN, Feigenbaum GS, Rodriguez JE, Valdes D, Pattany PM, Zambrano JP, Hu Q McNiece I, Heldman AW, Hare JM: Allogeneic mesenchymal stem cells restore cardiac function in chronic ischemic cardiomyopathy via trilineage differentiating capacity. Proc Natl Acad Sci U S A 2009;106:14022-14027.

-268 Murry CE, Soonpaa MH, Reinecke H, Nakajima H, Nakajima HO, Rubart M, Pasumarthi KBS, Virag JI, Bartelmez SH, Poppa V, Bradford G, Dowell JD, Williams DA, Field LJ: Haematopoietic stem cells do not transdifferentiate into cardiac myocytes in myocardial infarcts. Nature 2004;428:664-668.

269 Balsam LB, Wagers AJ, Christensen JL, Kofidis T, Weissman IL, Robbins RC: Haematopoietic stem cells adopt mature haematopoietic fates in ischaemic myocardium. Nature 2004;428:668-673.

-270 Yoshioka T, Ageyama N, Shibata H, Yasu T, Misawa Y, Takeuchi K, Matsui K, Yamamoto K, Terao K, Shimada K, Ikeda U, Ozawa K, Hanazono Y: Repair of infarcted myocardium mediated by transplanted bone marrowderived CD34+ stem cells in a nonhuman primate model. Stem Cells 2005;23:355-364.

271 Iso Y, Spees JL, Serrano C, Bakondi B, Pochampally R, Song YH, Sobel BE, Delafontaine P, Prockop DJ: Multipotent human stromal cells improve cardiac function after myocardial infarction in mice without longterm engraftment. Biochem Biophys Res Commun 2007;354:700-706.

272 Nygren JM, Jovinge S, Breitbach M, Sawen P, Roll W, Hescheler J, Taneera J, Fleischmann BK, Jacobsen SEW: Bone marrow-derived hematopoietic cells generate cardiomyocytes at a low frequency through cell fusion, but not transdifferentiation. Nat Med 2004;10:494-501.

273 Andrade J, Lam JT, Zamora M, Huang C, Franco D, Sevilla N, Gruber PJ, Lu JT, Ruiz-Lozano P: Predominant fusion of bone marrow-derived cardiomyocytes. Cardiovasc Res 2005;68:387-393.

274 Alvarez-Dolado M, Pardal R, Garcia-Verdugo JM, Fike JR, Lee HO, Pfeffer K, Lois C, Morrison SJ, AlvarezBuylla A: Fusion of bone-marrow-derived cells with Purkinje neurons, cardiomyocytes and hepatocytes. Nature 2003;425:968-973.

-275 Zhang S, Wang D, Estrov Z, Raj S, Willerson JT, Yeh ETH: Both cell fusion and transdifferentiation account for the transformation of human peripheral blood CD34-positive cells into cardiomyocytes in vivo. Circulation 2004;110:3803-3807.

-276 Iwasaki H, Kawamoto A, Ishikawa M, Oyamada A, Nakamori S, Nishimura H, Sadamoto K, Horii M, Matsumoto T, Murasawa S, Shibata T, Suehiro S, Asahara T: Dose-dependent contribution of CD34-positive cell transplantation to concurrent vasculogenesis and cardiomyogenesis for functional regenerative recovery after myocardial infarction. Circulation 2006;113:1311-1325.

277 Yeh ETH, Zhang S, Wu HD, Korbling M, Willerson JT, Estrov Z: Transdifferentiation of human peripheral blood CD34+-enriched cell population into cardiomyocytes, endothelial cells, and smooth muscle cells in vivo. Circulation 2003;108:2070-2073.

278 Bai X, Yan Y, Song YH, Seidensticker M, Rabinovich B, Metzele R, Bankson JA, Vykoukal D, Alt E: Both cultured and freshly isolated adipose tissue-derived stem cells enhance cardiac function after acute myocardial infarction. Eur Heart J 2010;31:489-501.

279 Dawn B, Stein AB, Urbanek K, Rota M, Whang B, Rastaldo R, Torella D, Tang XL, Rezazadeh A, Kajstura J, Leri A, Hunt G, Varma J, Prabhu SD, Anversa P, Bolli R: Cardiac stem cells delivered intravascularly traverse the vessel barrier, regenerate infarcted myocardium, and improve cardiac function. Proc Natl Acad Sci U S A 2005;102:3766-3771. 


\section{Cellular Physiology Cell Physiol Biochem 2018;48:2607-2655 \begin{tabular}{l|l|l} 
DOI: 10.1159/000492704 & $\begin{array}{l}\text { O 2018 The Author(s). Published by S. Karger AG, Basel } \\
\text { www.karger.com/cpb }\end{array}$
\end{tabular} \\ Müller et al.: Cardiac Stem Cell Therapy}

280 D’Alessandro DA, Kajstura J, Hosoda T, Gatti A, Bello R, Mosna F, Bardelli S, Zheng H, D’Amario D, PadinIruegas ME, Carvalho AB, Rota M, Zembala MO, Stern D, Rimoldi O, Urbanek K, Michler RE, Leri A, Anversa P: Progenitor cells from the explanted heart generate immunocompatible myocardium within the transplanted donor heart. Circ Res 2009;105:1128-1140.

-281 Smits AM, van Laake LW, den Ouden K, Schreurs C, Szuhai K, van Echteld CJ, Mummery CL, Doevendans PA, Goumans MJ: Human cardiomyocyte progenitor cell transplantation preserves long-term function of the infarcted mouse myocardium. Cardiovasc Res 2009;83:527-535.

-282 Rota M, Padin-Iruegas ME, Misao Y, de Angelis A, Maestroni S, Ferreira-Martins J, Fiumana E, Rastaldo R, Arcarese ML, Mitchell TS, Boni A, Bolli R, Urbanek K, Hosoda T, Anversa P, Leri A, Kajstura J: Local activation or implantation of cardiac progenitor cells rescues scarred infarcted myocardium improving cardiac function. Circ Res 2008;103:107-116.

283 Tang XL, Li Q, Rokosh G, Sanganalmath SK, Chen N, Ou Q, Stowers H, Hunt G, Bolli R: Long-Term Outcome of Administration of c-kit(POS) Cardiac Progenitor Cells After Acute Myocardial Infarction: Transplanted Cells Do not Become Cardiomyocytes, but Structural and Functional Improvement and Proliferation of Endogenous Cells Persist for at Least One Year. Circ Res 2016;118:1091-1105.

-284 Tang XL, Rokosh G, Sanganalmath SK, Yuan F, Sato H, Mu J, Dai S, Li C, Chen N, Peng Y, Dawn B, Hunt G, Leri A, Kajstura J, Tiwari S, Shirk G, Anversa P, Bolli R: Intracoronary administration of cardiac progenitor cells alleviates left ventricular dysfunction in rats with a 30-day-old infarction. Circulation 2010;121:293-305.

-285 van Berlo JH, Kanisicak O, Maillet M, Vagnozzi RJ, Karch J, Lin SC, Middleton RC, Marban E, Molkentin JD: c-kit+ cells minimally contribute cardiomyocytes to the heart. Nature 2014;509:337-341.

286 Sultana N, Zhang L, Yan J, Chen J, Cai W, Razzaque S, Jeong D, Sheng W, Bu L, Xu M, Huang GY, Hajjar RJ, Zhou B, Moon A, Cai CL: Resident c-kit(+) cells in the heart are not cardiac stem cells. Nat Commun 2015;6:8701.

287 Gallina C, Turinetto V, Giachino C: A New Paradigm in Cardiac Regeneration: The Mesenchymal Stem Cell Secretome. Stem Cells Int 2015;2015:765846.

288 Hodgkinson CP, Bareja A, Gomez JA, Dzau VJ: Emerging Concepts in Paracrine Mechanisms in Regenerative Cardiovascular Medicine and Biology. Circ Res 2016;118:95-107.

289 Plotnikov EY, Silachev DN, Popkov VA, Zorova LD, Pevzner IB, Zorov SD, Jankauskas SS, Babenko VA, Sukhikh GT, Zorov DB: Intercellular Signalling Cross-Talk: To Kill, To Heal and To Rejuvenate. Heart Lung Circ 2017;26:648-659.

290 Mirotsou M, Jayawardena TM, Schmeckpeper J, Gnecchi M, Dzau VJ: Paracrine mechanisms of stem cell reparative and regenerative actions in the heart. J Mol Cell Cardiol 2011;50:280-289.

291 Cheng K, Malliaras K, Smith RR, Shen D, Sun B, Blusztajn A, Xie Y, Ibrahim A, Aminzadeh MA, Liu W, Li TS, Robertis MA de, Marbán L, Czer LSC, Trento A, Marbán E: Human cardiosphere-derived cells from advanced heart failure patients exhibit augmented functional potency in myocardial repair. JACC Heart Fail 2014;2:49-61.

-292 Sharma S, Mishra R, Bigham GE, Wehman B, Khan MM, Xu H, Saha P, Goo YA, Datla SR, Chen L, Tulapurkar ME, Taylor BS, Yang P, Karathanasis S, Goodlett DR, Kaushal S: A Deep Proteome Analysis Identifies the Complete Secretome as the Functional Unit of Human Cardiac Progenitor Cells. Circ Res 2017;120:816-834.

-293 Agarwal U, George A, Bhutani S, Ghosh-Choudhary S, Maxwell JT, Brown ME, Mehta Y, Platt MO, Liang Y, Sahoo S, Davis ME: Experimental, Systems, and Computational Approaches to Understanding the MicroRNA-Mediated Reparative Potential of Cardiac Progenitor Cell-Derived Exosomes From Pediatric Patients. Circ Res 2017;120:701-712.

294 Khanabdali R, Rosdah AA, Dusting GJ, Lim SY: Harnessing the secretome of cardiac stem cells as therapy for ischemic heart disease. Biochem Pharmacol 2016;113:1-11.

295 Bianconi V, Sahebkar A, Kovanen P, Bagaglia F, Ricciuti B, Calabrò P, Patti G, Pirro M: Endothelial and cardiac progenitor cells for cardiovascular repair: A controversial paradigm in cell therapy. Pharmacol Ther 2018;181:156-168.

296 Redgrave RE, Tual-Chalot S, Davison BJ, Singh E, Hall D, Amirrasouli MM, Gilchrist D, Medvinsky A, Arthur HM: Cardiosphere-Derived Cells Require Endoglin for Paracrine-Mediated Angiogenesis. Stem Cell Reports 2017;8:1287-1298.

297 Bao L, Meng Q, Li Y, Deng S, Yu Z, Liu Z, Zhang L, Fan H: C-Kit Positive Cardiac Stem Cells and Bone MarrowDerived Mesenchymal Stem Cells Synergistically Enhance Angiogenesis and Improve Cardiac Function After Myocardial Infarction in a Paracrine Manner. J Card Fail 2017;23:403-415. 


\section{Cellular Physiology Cell Physiol Biochem 2018;48:2607-2655 \begin{tabular}{ll|l} 
DOI: 10.1159/000492704 & $\begin{array}{l}\text { O 2018 The Author(s). Published by S. Karger AG, Basel } \\
\text { www.karger.com/cpb }\end{array}$
\end{tabular}

298 Zhao L, Johnson T, Liu D: Therapeutic angiogenesis of adipose-derived stem cells for ischemic diseases. Stem Cell Res Ther 2017;8:125.

299 Liang X, Ding Y, Zhang Y, Tse HF, Lian Q: Paracrine mechanisms of mesenchymal stem cell-based therapy: current status and perspectives. Cell Transplant 2014;23:1045-1059.

-300 Timmers L, Lim SK, Hoefer IE, Arslan F, Lai RC, van Oorschot AAM, Goumans MJ, Strijder C, Sze SK, Choo A, Piek JJ, Doevendans PA, Pasterkamp G, de Kleijn DP: Human mesenchymal stem cell-conditioned medium improves cardiac function following myocardial infarction. Stem Cell Res 2011;6:206-214.

301 Chen JJ, Zhou SH: Mesenchymal stem cells overexpressing MiR-126 enhance ischemic angiogenesis via the AKT/ERK-related pathway. Cardiol J 2011;18:675-681.

-302 Ma N, Ladilov Y, Moebius JM, Ong L, Piechaczek C, Dávid A, Kaminski A, Choi YH, Li W, Egger D, Stamm C, Steinhoff G: Intramyocardial delivery of human CD133+ cells in a SCID mouse cryoinjury model: Bone marrow vs. cord blood-derived cells. Cardiovasc Res 2006;71:158-169.

-303 Skorska A, Müller P, Gaebel R, Große J, Lemcke H, Lux CA, Bastian M, Hausburg F, Zarniko N, Bubritzki S, Ruch U, Tiedemann G, David R, Steinhoff G: GMP-conformant on-site manufacturing of a CD133+ stem cell product for cardiovascular regeneration. Stem Cell Res Ther 2017;8:33.

304 Bongiovanni D, Bassetti B, Gambini E, Gaipa G, Frati G, Achilli F, Scacciatella P, Carbucicchio C, Pompilio G: The CD133+ cell as advanced medicinal product for myocardial and limb ischemia. Stem Cells Dev 2014;23:2403-2421.

305 Li N, Hua J: Interactions between mesenchymal stem cells and the immune system. Cell Mol Life Sci 2017;74:2345-2360.

-306 Epstein SE, Luger D, Lipinski MJ: Paracrine-Mediated Systemic Anti-Inflammatory Activity of Intravenously Administered Mesenchymal Stem Cells: A Transformative Strategy for Cardiac Stem Cell Therapeutics. Circ Res 2017;121:1044-1046.

307 Di Nicola M, Carlo-Stella C, Magni M, Milanesi M, Longoni PD, Matteucci P, Grisanti S, Gianni AM: Human bone marrow stromal cells suppress T-lymphocyte proliferation induced by cellular or nonspecific mitogenic stimuli. Blood 2002;99:3838-38343.

-308 Glennie S, Soeiro I, Dyson PJ, Lam EW-F, Dazzi F: Bone marrow mesenchymal stem cells induce division arrest anergy of activated T cells. Blood 2005;105:2821-2827.

-309 Selmani Z, Naji A, Zidi I, Favier B, Gaiffe E, Obert L, Borg C, Saas P, Tiberghien P, Rouas-Freiss N, Carosella ED, Deschaseaux F: Human leukocyte antigen-G5 secretion by human mesenchymal stem cells is required to suppress $\mathrm{T}$ lymphocyte and natural killer function and to induce CD4+CD25highFOXP3+ regulatory $\mathrm{T}$ cells. Stem Cells 2008;26:212-222.

310 Meisel R, Zibert A, Laryea M, Göbel U, Däubener W, Dilloo D: Human bone marrow stromal cells inhibit allogeneic T-cell responses by indoleamine 2,3-dioxygenase-mediated tryptophan degradation. Blood 2004;103:4619-4621.

-311 Sato K, Ozaki K, Oh I, Meguro A, Hatanaka K, Nagai T, Muroi K, Ozawa K: Nitric oxide plays a critical role in suppression of T-cell proliferation by mesenchymal stem cells. Blood 2007;109:228-234.

-312 Plumas J, Chaperot L, Richard J, Molens J-P Bensa J-C, Favrot MC: Mesenchymal stem cells induce apoptosis of activated T cells. Leukemia 2005;19:1597-1604.

-313 Akiyama K, Chen C, Wang D, Xu X, Qu C, Yamaza T, Cai T, Chen W, Sun L, Shi S: Mesenchymal-stemcell-induced immunoregulation involves FAS-ligand-/FAS-mediated T cell apoptosis. Cell Stem Cell 2012;10:544-555.

314 Davies LC, Heldring N, Kadri N, Le Blanc K: Mesenchymal Stromal Cell Secretion of Programmed Death-1 Ligands Regulates T Cell Mediated Immunosuppression. Stem Cells 2017;35:766-776.

315 Luz-Crawford P, Kurte M, Bravo-Alegría J, Contreras R, Nova-Lamperti E, Tejedor G, Noël D, Jorgensen C, Figueroa F, Djouad F, Carrión F: Mesenchymal stem cells generate a CD4+CD25+Foxp3+ regulatory T cell population during the differentiation process of Th1 and Th17 cells. Stem Cell Res Ther 2013;4:65.

316 Zhang B, Yin Y, Lai RC, Tan SS, Choo ABH, Lim SK: Mesenchymal stem cells secrete immunologically active exosomes. Stem Cells Dev 2014;23:1233-1244.

317 Nahrendorf M, Swirski FK: Regulating repair: regulatory T cells in myocardial infarction. Circ Res 2014;115:7-9.

318 Hofmann U, Frantz S: Role of lymphocytes in myocardial injury, healing, and remodeling after myocardial infarction. Circ Res 2015;116:354-367. 


\section{Cellular Physiology Cell Physiol Biochem 2018;48:2607-2655 \begin{tabular}{ll|l} 
and Biochemistry Published onlIne: 16 August, 2018 & $\begin{array}{l}\text { (c) } 2018 \text { The Author(s). Published by S. Karger AG, Basel } \\
\text { www.karger.com/cpb }\end{array}$
\end{tabular} \\ Müller et al.: Cardiac Stem Cell Therapy}

319 Ren G, Zhang L, Zhao X, Xu G, Zhang Y, Roberts AI, Zhao RC, Shi Y: Mesenchymal stem cell-mediated immunosuppression occurs via concerted action of chemokines and nitric oxide. Cell Stem Cell 2008;2:141-150.

320 Crop MJ, Baan CC, Korevaar SS, Ijzermans JNM, Pescatori M, Stubbs AP, van Ijcken WFJ, Dahlke MH, Eggenhofer E, Weimar W, Hoogduijn MJ: Inflammatory conditions affect gene expression and function of human adipose tissue-derived mesenchymal stem cells. Clin Exp Immunol 2010;162:474-486.

-321 Bernardo ME, Fibbe WE: Mesenchymal stromal cells: sensors and switchers of inflammation. Cell Stem Cell 2013;13:392-402.

-322 Li W, Ren G, Huang Y, Su J, Han Y, Li J, Chen X, Cao K, Chen Q, Shou P, Zhang L, Yuan Z-R, Roberts AI, Shi S, Le AD, Shi Y: Mesenchymal stem cells: a double-edged sword in regulating immune responses. Cell Death Differ 2012;19:1505-1513.

-323 Gombozhapova A, Rogovskaya Y, Shurupov V, Rebenkova M, Kzhyshkowska J, Popov SV, Karpov RS, Ryabov V: Macrophage activation and polarization in post-infarction cardiac remodeling. J Biomed Sci 2017;24:13.

324 Wise AF, Williams TM, Kiewiet MBG, Payne NL, Siatskas C, Samuel CS, Ricardo SD: Human mesenchymal stem cells alter macrophage phenotype and promote regeneration via homing to the kidney following ischemia-reperfusion injury. Am J Physiol Renal Physiol 2014;306:F1222-1235.

325 Hasan AS, Luo L, Yan C, Zhang TX, Urata Y, Goto S, Mangoura SA, Abdel-Raheem MH, Zhang S, Li TS: Cardiosphere-Derived Cells Facilitate Heart Repair by Modulating M1/M2 Macrophage Polarization and Neutrophil Recruitment. PLoS One 2016;11:e0165255.

326 Cho DI, Kim MR, Jeong HY, Jeong HC, Jeong MH, Yoon SH, Kim YS, Ahn Y: Mesenchymal stem cells reciprocally regulate the M1/M2 balance in mouse bone marrow-derived macrophages. Exp Mol Med 2014;46:e70.

327 Geng Y, Zhang L, Fu B, Zhang J, Hong Q Hu J, Li D, Luo C, Cui S, Zhu F, Chen X: Mesenchymal stem cells ameliorate rhabdomyolysis-induced acute kidney injury via the activation of M2 macrophages. Stem Cell Res Ther 2014;5:80.

328 Luz-Crawford P, Djouad F, Toupet K, Bony C, Franquesa M, Hoogduijn MJ, Jorgensen C, Noël D: Mesenchymal Stem Cell-Derived Interleukin 1 Receptor Antagonist Promotes Macrophage Polarization and Inhibits B Cell Differentiation. Stem Cells 2016;34:483-492.

329 François M, Romieu-Mourez R, Li M, Galipeau J: Human MSC suppression correlates with cytokine induction of indoleamine 2,3-dioxygenase and bystander M2 macrophage differentiation. Mol Ther 2012;20:187-195.

330 Ylöstalo JH, Bartosh TJ, Coble K, Prockop DJ: Human mesenchymal stem/stromal cells cultured as spheroids are self-activated to produce prostaglandin E2 that directs stimulated macrophages into an antiinflammatory phenotype. Stem Cells 2012;30:2283-2296.

331 Németh K, Leelahavanichkul A, Yuen PST, Mayer B, Parmelee A, Doi K, Robey PG, Leelahavanichkul K, Koller BH, Brown JM, Hu X, Jelinek I, Star RA, Mezey E: Bone marrow stromal cells attenuate sepsis via prostaglandin $\mathrm{E}(2)$-dependent reprogramming of host macrophages to increase their interleukin-10 production. Nat Med 2009;15:42-49.

-332 Tabera S, Pérez-Simón JA, Díez-Campelo M, Sánchez-Abarca LI, Blanco B, López A, Benito A, Ocio E, SánchezGuijo FM, Cañizo C, San Miguel JF: The effect of mesenchymal stem cells on the viability, proliferation and differentiation of B-lymphocytes. Haematologica 2008;93:1301-1309.

-333 Corcione A, Benvenuto F, Ferretti E, Giunti D, Cappiello V, Cazzanti F, Risso M, Gualandi F, Mancardi GL, Pistoia V, Uccelli A: Human mesenchymal stem cells modulate B-cell functions. Blood 2006;107:367-372.

-334 Sotiropoulou PA, Perez SA, Gritzapis AD, Baxevanis CN, Papamichail M: Interactions between human mesenchymal stem cells and natural killer cells. Stem Cells 2006;24:74-85.

335 Spaggiari GM, Capobianco A, Abdelrazik H, Becchetti F, Mingari MC, Moretta L: Mesenchymal stem cells inhibit natural killer-cell proliferation, cytotoxicity, and cytokine production: role of indoleamine 2,3-dioxygenase and prostaglandin E2. Blood 2008;111:1327-1333.

-336 Zhang W, Ge W, Li C, You S, Liao L, Han Q, Deng W, Zhao RCH: Effects of mesenchymal stem cells on differentiation, maturation, and function of human monocyte-derived dendritic cells. Stem Cells Dev 2004;13:263-271.

-337 Jiang XX, Zhang Y, Liu B, Zhang S-X, Wu Y, Yu XD, Mao N: Human mesenchymal stem cells inhibit differentiation and function of monocyte-derived dendritic cells. Blood 2005;105:4120-4126. 


\section{Cellular Physiology Cell Physiol Biochem 2018;48:2607-2655 \begin{tabular}{ll|l} 
and Biochemistry Published onlIne: 16 August, 2018 & $\begin{array}{l}\text { (c) } 2018 \text { The Author(s). Published by S. Karger AG, Basel } \\
\text { www.karger.com/cpb }\end{array}$
\end{tabular} \\ Müller et al.: Cardiac Stem Cell Therapy}

338 English K, Barry FP, Mahon BP: Murine mesenchymal stem cells suppress dendritic cell migration, maturation and antigen presentation. Immunol Lett 2008;115:50-58.

339 Brown JM, Nemeth K, Kushnir-Sukhov NM, Metcalfe DD, Mezey E: Bone marrow stromal cells inhibit mast cell function via a COX2-dependent mechanism. Clin Exp Allergy 2011;41:526-534.

340 Liu J, Kuwabara A, Kamio Y, Hu S, Park J, Hashimoto T, Lee JW: Human Mesenchymal Stem Cell-Derived Microvesicles Prevent the Rupture of Intracranial Aneurysm in Part by Suppression of Mast Cell Activation via a PGE2-Dependent Mechanism. Stem Cells 2016;34:2943-2955.

-341 Kim S, Yun J-W, Shin TH, Lee H, Lee B-C, Yu KR, Seo Y, Lee S, Kang TW, Choi SW, Seo KW, Kang KS: Human umbilical cord blood mesenchymal stem cell-derived PGE2 and TGF- $\beta 1$ alleviate atopic dermatitis by reducing mast cell degranulation. Stem Cells 2015;33:1254-1266.

-342 Raffaghello L, Bianchi G, Bertolotto M, Montecucco F, Busca A, Dallegri F, Ottonello L, Pistoia V: Human mesenchymal stem cells inhibit neutrophil apoptosis: a model for neutrophil preservation in the bone marrow niche. Stem Cells 2008;26:151-162.

343 Cassatella MA, Mosna F, Micheletti A, Lisi V, Tamassia N, Cont C, Calzetti F, Pelletier M, Pizzolo G, Krampera M: Toll-like receptor-3-activated human mesenchymal stromal cells significantly prolong the survival and function of neutrophils. Stem Cells 2011;29:1001-1011.

344 Brandau S, Jakob M, Hemeda H, Bruderek K, Janeschik S, Bootz F, Lang S: Tissue-resident mesenchymal stem cells attract peripheral blood neutrophils and enhance their inflammatory activity in response to microbial challenge. J Leukoc Biol 2010;88:1005-1015.

-345 Yu PF, Huang Y, Han YY, Lin LY, Sun WH, Rabson AB, Wang Y, Shi YF: TNF $\alpha$-activated mesenchymal stromal cells promote breast cancer metastasis by recruiting CXCR2+ neutrophils. Oncogene 2017;36:482-490.

-346 Jiang D, Muschhammer J, Qi Y, Kügler A, de Vries JC, Saffarzadeh M, Sindrilaru A, Beken SV, Wlaschek M, Kluth MA, Ganss C, Frank NY, Frank MH, Preissner KT, Scharffetter-Kochanek K: Suppression of NeutrophilMediated Tissue Damage-A Novel Skill of Mesenchymal Stem Cells. Stem Cells 2016;34:2393-2406.

347 Munir H, Luu N-T, Clarke LSC, Nash GB, McGettrick HM: Comparative Ability of Mesenchymal Stromal Cells from Different Tissues to Limit Neutrophil Recruitment to Inflamed Endothelium. PLoS One 2016;11:e0155161.

-348 Luger D, Lipinski MJ, Westman PC, Glover DK, Dimastromatteo J, Frias JC, Albelda MT, Sikora S, Kharazi A, Vertelov G, Waksman R, Epstein SE: Intravenously Delivered Mesenchymal Stem Cells: Systemic AntiInflammatory Effects Improve Left Ventricular Dysfunction in Acute Myocardial Infarction and Ischemic Cardiomyopathy. Circ Res 2017;120:1598-1613.

349 Melief SM, Zwaginga JJ, Fibbe WE, Roelofs H: Adipose tissue-derived multipotent stromal cells have a higher immunomodulatory capacity than their bone marrow-derived counterparts. Stem Cells Transl Med 2013;2:455-463.

-350 Ivanova-Todorova E, Bochev I, Mourdjeva M, Dimitrov R, Bukarev D, Kyurkchiev S, Tivchev P, Altunkova I, Kyurkchiev DS: Adipose tissue-derived mesenchymal stem cells are more potent suppressors of dendritic cells differentiation compared to bone marrow-derived mesenchymal stem cells. Immunol Lett 2009;126:37-42.

-351 Blanco B, Herrero-Sánchez MDC, Rodríguez-Serrano C, García-Martínez ML, Blanco JF, Muntión S, GarcíaArranz M, Sánchez-Guijo F, Del Cañizo C: Immunomodulatory effects of bone marrow versus adipose tissuederived mesenchymal stromal cells on NK cells: implications in the transplantation setting. Eur J Haematol 2016;97:528-537.

352 Valencia J, Blanco B, Yáñez R, Vázquez M, Herrero Sánchez C, Fernández-García M, Rodríguez Serrano C, Pescador D, Blanco JF, Hernando-Rodríguez M, Sánchez-Guijo F, Lamana ML, Segovia JC, Vicente Á, Del Cañizo C, Zapata AG: Comparative analysis of the immunomodulatory capacities of human bone marrowand adipose tissue-derived mesenchymal stromal cells from the same donor. Cytotherapy 2016;18:12971311.

353 Loffredo FS, Steinhauser ML, Gannon J, Lee RT: Bone marrow-derived cell therapy stimulates endogenous cardiomyocyte progenitors and promotes cardiac repair. Cell Stem Cell 2011;8:389-398.

354 Wehman B, Sharma S, Pietris N, Mishra R, Siddiqui OT, Bigham G, Li T, Aiello E, Murthi S, Pittenger M, Griffith B, Kaushal S: Mesenchymal stem cells preserve neonatal right ventricular function in a porcine model of pressure overload. Am J Physiol Heart Circ Physiol 2016;310:H1816-26.

355 Wang QL, Wang HJ, Li ZH, Wang YL, Wu P, Tan YZ: Mesenchymal stem cell-loaded cardiac patch promotes epicardial activation and repair of the infarcted myocardium. J Cell Mol Med 2017;21:1751-1766. 


\section{Cellular Physiology Cell Physiol Biochem 2018;48:2607-2655 \begin{tabular}{ll|l} 
and Biochemistry Publisned onIIne: 16 August, 2018 & $\begin{array}{l}\text { (c) } 2018 \text { The Author(s). Published by S. Karger AG, Basel } \\
\text { www.karger.com/cpb }\end{array}$ \\
\hline
\end{tabular} \\ Müller et al.: Cardiac Stem Cell Therapy}

-356 Golle L, Gerth HU, Beul K, Heitplatz B, Barth P, Fobker M, Pavenstädt H, Di Marco GS, Brand M: Bone marrow-derived cells and their conditioned medium induce microvascular repair in uremic rats by stimulation of endogenous repair mechanisms. Sci Rep 2017;7:9444.

357 Boni A, Urbanek K, Nascimbene A, Hosoda T, Zheng H, Delucchi F, Amano K, Gonzalez A, Vitale S, Ojaimi C, Rizzi R, Bolli R, Yutzey KE, Rota M, Kajstura J, Anversa P, Leri A: Notch1 regulates the fate of cardiac progenitor cells. Proc Natl Acad Sci U S A 2008;105:15529-15534.

358 Li G, Chen J, Zhang X, He G, Tan W, Wu H, Li R, Chen Y, Gu R, Xie J, Xu B: Cardiac repair in a mouse model of acute myocardial infarction with trophoblast stem cells. Sci Rep 2017;7:44376.

-359 Acquistapace A, Bru T, Lesault P-F, Figeac F, Coudert AE, Le Coz O, Christov C, Baudin X, Auber F, Yiou R, Dubois-Rande JL, Rodriguez AM: Human mesenchymal stem cells reprogram adult cardiomyocytes toward a progenitor-like state through partial cell fusion and mitochondria transfer. Stem Cells 2011;29:812-824.

-360 Zhang S, Shpall E, Willerson JT, Yeh ETH: Fusion of human hematopoietic progenitor cells and murine cardiomyocytes is mediated by alpha 4 beta 1 integrin/vascular cell adhesion molecule- 1 interaction. Circ Res 2007;100:693-702.

361 Azevedo PS, Polegato BF, Minicucci MF, Paiva SAR, Zornoff LAM: Cardiac Remodeling: Concepts, Clinical Impact, Pathophysiological Mechanisms and Pharmacologic Treatment. Arq Bras Cardiol 2016;106:62-69.

362 Savi M, Bocchi L, Rossi S, Frati C, Graiani G, Lagrasta C, Miragoli M, Di Pasquale E, Stirparo GG, Mastrototaro G, Urbanek K, Angelis A de, Macchi E, Stilli D, Quaini F, Musso E: Antiarrhythmic effect of growth factorsupplemented cardiac progenitor cells in chronic infarcted heart. Am J Physiol Heart Circ Physiol 2016;310:H1622-1648.

-363 Tokita Y, Tang X-L, Li Q, Wysoczynski M, Hong KU, Nakamura S, Wu WJ, Xie W, Li D, Hunt G, Ou Q Stowers H, Bolli R: Repeated Administrations of Cardiac Progenitor Cells Are Markedly More Effective Than a Single Administration: A New Paradigm in Cell Therapy. Circ Res 2016;119:635-651.

-364 Mias C, Lairez O, Trouche E, Roncalli J, Calise D, Seguelas MH, Ordener C, Piercecchi-Marti MD, Auge N, Salvayre AN, Bourin P, Parini A, Cussac D: Mesenchymal stem cells promote matrix metalloproteinase secretion by cardiac fibroblasts and reduce cardiac ventricular fibrosis after myocardial infarction. Stem Cells 2009;27:2734-2743.

-365 Zhang GW, Gu TX, Guan XY, Sun J, Qi X, Li X-Y, Wang XB, Yu L, Jiang DQ, Tang R, Li-Ling J: bFGF binding cardiac extracellular matrix promotes the repair potential of bone marrow mesenchymal stem cells in a rabbit model for acute myocardial infarction. Biomed Mater 2015;10:65018.

-366 Liu C-B, Huang H, Sun P, Ma Z, Liu A-H, Xue J, Fu JH, Liang YQ, Liu B, Wu DY, Lü SH, Zhang XZ: Human Umbilical Cord-Derived Mesenchymal Stromal Cells Improve Left Ventricular Function, Perfusion, and Remodeling in a Porcine Model of Chronic Myocardial Ischemia. Stem Cells Transl Med 2016;5:1004-1013.

367 Deng B, Wang JX, Hu XX, Duan P, Wang L, Li Y, Zhu QL: Nkx2.5 enhances the efficacy of mesenchymal stem cells transplantation in treatment heart failure in rats. Life Sci 2017;182:65-72.

368 Müller P, Gaebel R, Lemcke H, Steinhoff G, David R: Data on the fate of MACS® MicroBeads intramyocardially co-injected with stem cell products. Data Brief 2017;13:569-574.

-369 Müller P, Gaebel R, Lemcke H, Wiekhorst F, Hausburg F, Lang C, Zarniko N, Westphal B, Steinhoff G, David R: Intramyocardial fate and effect of iron nanoparticles co-injected with MACS(R) purified stem cell products. Biomaterials 2017;135:74-84.

370 Meier RPH, Mahou R, Morel P, Meyer J, Montanari E, Muller YD, Christofilopoulos P, Wandrey C, GonelleGispert C, Bühler LH: Microencapsulated human mesenchymal stem cells decrease liver fibrosis in mice. J Hepatol 2015;62:634-641.

371 Xu L, Ding L, Wang L, Cao Y, Zhu H, Lu J, Li X, Song T, Hu Y, Dai J: Umbilical cord-derived mesenchymal stem cells on scaffolds facilitate collagen degradation via upregulation of MMP-9 in rat uterine scars. Stem Cell Res Ther 2017;8:84.

372 Shen D, Tang J, Hensley MT, Li T, Caranasos TG, Zhang T, Zhang J, Cheng K: Effects of Matrix Metalloproteinases on the Performance of Platelet Fibrin Gel Spiked With Cardiac Stem Cells in Heart Repair. Stem Cells Transl Med 2016;5:793-803.

-373 Nagaya N, Kangawa K, Itoh T, Iwase T, Murakami S, Miyahara Y, Fujii T, Uematsu M, Ohgushi H, Yamagishi M, Tokudome T, Mori H, Miyatake K, Kitamura S: Transplantation of mesenchymal stem cells improves cardiac function in a rat model of dilated cardiomyopathy. Circulation 2005;112:1128-1135. 


\section{Cellular Physiology Cell Physiol Biochem 2018;48:2607-2655 \begin{tabular}{l|l|l} 
and Biochemistry & $\begin{array}{l}\text { DOI: 10.1159/000492704 } \\
\text { Publisned } 2018 \text { The Author(s). Published by S. Karger AG, Basel }\end{array}$ \\
\hline
\end{tabular} \\ Müller et al.: Cardiac Stem Cell Therapy}

374 Huang W, Wang T, Zhang D, Zhao T, Dai B, Ashraf A, Wang X, Xu M, Millard RW, Fan GC, Ashraf M, Yu XY, Wang Y: Mesenchymal stem cells overexpressing CXCR4 attenuate remodeling of postmyocardial infarction by releasing matrix metalloproteinase-9. Stem Cells Dev 2012;21:778-789.

-375 Hattori H, Ishihara M: Altered protein secretions during interactions between adipose tissue- or bone marrow-derived stromal cells and inflammatory cells. Stem Cell Res Ther 2015;6:70.

-376 Dabrowski FA, Burdzinska A, Kulesza A, Sladowska A, Zolocinska A, Gala K, Paczek L, Wielgos M: Comparison of the paracrine activity of mesenchymal stem cells derived from human umbilical cord, amniotic membrane and adipose tissue. J Obstet Gynaecol Res 2017;43:1758-1768.

-377 Martire A, Bedada FB, Uchida S, Pöling J, Krüger M, Warnecke H, Richter M, Kubin T, Herold S, Braun T: Mesenchymal stem cells attenuate inflammatory processes in the heart and lung via inhibition of TNF signaling. Basic Res Cardiol 2016;111:54.

378 Lee RH, Pulin AA, Seo MJ, Kota DJ, Ylostalo J, Larson BL, Semprun-Prieto L, Delafontaine P, Prockop DJ: Intravenous hMSCs improve myocardial infarction in mice because cells embolized in lung are activated to secrete the anti-inflammatory protein TSG-6. Cell Stem Cell 2009;5:54-63.

-379 van der Spoel TI, Jansen of Lorkeers SJ, Agostoni P, van Belle E, Gyöngyösi M, Sluijter JPG, Cramer MJ, Doevendans PA, Chamuleau SAJ: Human relevance of pre-clinical studies in stem cell therapy: systematic review and meta-analysis of large animal models of ischaemic heart disease. Cardiovasc Res 2011;91:649658.

380 Lang CI, Wolfien M, Langenbach A, Müller P, Wolkenhauer O, Yavari A, Ince H, Steinhoff G, Krause BJ, David R, Glass Ä: Cardiac Cell Therapies for the Treatment of Acute Myocardial Infarction: A Meta-Analysis from Mouse Studies. Cell Physiol Biochem 2017;42:254-268.

381 Nguyen PK, Rhee JW, Wu JC: Adult Stem Cell Therapy and Heart Failure, 2000 to 2016: A Systematic Review. JAMA Cardiol 2016;1:831-841.

-382 Afzal MR, Samanta A, Shah ZI, Jeevanantham V, Abdel-Latif A, Zuba-Surma EK, Dawn B: Adult Bone Marrow Cell Therapy for Ischemic Heart Disease: Evidence and Insights From Randomized Controlled Trials. Circ Res 2015;117:558-575.

383 Abdel-Latif A, Bolli R, Tleyjeh IM, Montori VM, Perin EC, Hornung CA, Zuba-Surma EK, Al-Mallah M, Dawn B: Adult bone marrow-derived cells for cardiac repair: a systematic review and meta-analysis. Arch Intern Med 2007;167:989-997.

-384 Xu R, Ding S, Zhao Y, Pu J, He B: Autologous transplantation of bone marrow/blood-derived cells for chronic ischemic heart disease: a systematic review and meta-analysis. Can J Cardiol 2014;30:1370-1377.

385 Delewi R, Hirsch A, Tijssen JG, Schächinger V, Wojakowski W, Roncalli J, Aakhus S, Erbs S, Assmus B, Tendera M, Goekmen Turan R, Corti R, Henry T, Lemarchand P, Lunde K, Cao F, Huikuri HV, Sürder D, Simari RD, Janssens S, et al.: Impact of intracoronary bone marrow cell therapy on left ventricular function in the setting of ST-segment elevation myocardial infarction: a collaborative meta-analysis. Eur Heart J 2014;35:989-998.

386 Lu Y, Wang Y, Lin M, Zhou J, Wang Z, Jiang M, He B: A systematic review of randomised controlled trials examining the therapeutic effects of adult bone marrow-derived stem cells for non-ischaemic dilated cardiomyopathy. Stem Cell Res Ther 2016;7:186.

387 Cong XQ, Li Y, Zhao X, Dai YJ, Liu Y: Short-Term Effect of Autologous Bone Marrow Stem Cells to Treat Acute Myocardial Infarction: A Meta-Analysis of Randomized Controlled Clinical Trials. J Cardiovasc Transl Res 2015;8:221-231.

388 Liu B, Duan Y, Luo C-F, Ou W, Sun K, Wu Z-, Huang H, Cheng C-, Li Y-P, Chen MS: Effectiveness and safety of selected bone marrow stem cells on left ventricular function in patients with acute myocardial infarction: a meta-analysis of randomized controlled trials. Int J Cardiol 2014;177:764-770.

389 Zhu K, Li J, Wang Y, Luo J, Zhang W, Guo C, Lai H, Wang C: Intramyocardial Autologous Bone Marrow-derived Stem Cells Injection for Ischemic Heart Disease Ineligible for Revascularization: A Systematic Review and Meta-analysis. Arch Med Res 2015;46:286-295.

390 Clifford DM, Fisher SA, Brunskill SJ, Doree C, Mathur A, Watt S, Martin-Rendon E: Stem cell treatment for acute myocardial infarction. Cochrane Database Syst Rev 2012:CD006536.

391 Zimmet H, Porapakkham P, Porapakkham P, Sata Y, Haas SJ, Itescu S, Forbes A, Krum H: Short- and longterm outcomes of intracoronary and endogenously mobilized bone marrow stem cells in the treatment of ST-segment elevation myocardial infarction: a meta-analysis of randomized control trials. Eur J Heart Fail 2012;14:91-105. 


\section{Cellular Physiology Cell Physiol Biochem 2018;48:2607-2655 \begin{tabular}{ll|l} 
and Biochemistry Publisned onIIne: 16 August, 2018 & $\begin{array}{l}\text { (c) } 2018 \text { The Author(s). Published by S. Karger AG, Basel } \\
\text { www.karger.com/cpb }\end{array}$ \\
\hline
\end{tabular} \\ Müller et al.: Cardiac Stem Cell Therapy}

392 Gyöngyösi M, Wojakowski W, Lemarchand P, Lunde K, Tendera M, Bartunek J, Marban E, Assmus B, Henry TD, Traverse JH, Moyé LA, Sürder D, Corti R, Huikuri H, Miettinen J, Wöhrle J, Obradovic S, Roncalli J, Malliaras K, Pokushalov E, et al.: Meta-Analysis of Cell-based CaRdiac stUdiEs (ACCRUE) in patients with acute myocardial infarction based on individual patient data. Circ Res 2015;116:1346-1360.

-393 Nowbar AN, Mielewczik M, Karavassilis M, Dehbi HM, Shun-Shin MJ, Jones S, Howard JP, Cole GD, Francis DP: Discrepancies in autologous bone marrow stem cell trials and enhancement of ejection fraction (DAMASCENE): weighted regression and meta-analysis. BMJ 2014;348:g2688.

-394 Der Sarkissian S, Lévesque T, Noiseux N: Optimizing stem cells for cardiac repair: Current status and new frontiers in regenerative cardiology. World J Stem Cells 2017;9:9-25.

-395 Noiseux N, Borie M, Desnoyers A, Menaouar A, Stevens LM, Mansour S, Danalache BA, Roy DC, Jankowski M, Gutkowska J: Preconditioning of stem cells by oxytocin to improve their therapeutic potential. Endocrinology 2012;153:5361-5372.

-396 Tan SC, Gomes RSM, Yeoh KK, Perbellini F, Malandraki-Miller S, Ambrose L, Heather LC, Faggian G, Schofield CJ, Davies KE, Clarke K, Carr CA: Preconditioning of Cardiosphere-Derived Cells With Hypoxia or Prolyl4-Hydroxylase Inhibitors Increases Stemness and Decreases Reliance on Oxidative Metabolism. Cell Transplant 2016;25:35-53.

397 Cai C, Teng L, Vu D, He JQ Guo Y, Li Q, Tang XL, Rokosh G, Bhatnagar A, Bolli R: The heme oxygenase 1 inducer (CoPP) protects human cardiac stem cells against apoptosis through activation of the extracellular signal-regulated kinase (ERK)/NRF2 signaling pathway and cytokine release. J Biol Chem 2012;287:3372033732.

398 Wisel S, Khan M, Kuppusamy ML, Mohan IK, Chacko SM, Rivera BK, Sun BC, Hideg K, Kuppusamy P: Pharmacological preconditioning of mesenchymal stem cells with trimetazidine (1-2,3,4-trimethoxybenzylpiperazine) protects hypoxic cells against oxidative stress and enhances recovery of myocardial function in infarcted heart through Bcl-2 expression. J Pharmacol Exp Ther 2009;329:543550.

399 Hoke NN, Salloum FN, Kass DA, Das A, Kukreja RC: Preconditioning by phosphodiesterase-5 inhibition improves therapeutic efficacy of adipose-derived stem cells following myocardial infarction in mice. Stem Cells 2012;30:326-335.

400 Mehmood A, Ali M, Khan SN, Riazuddin S: Diazoxide preconditioning of endothelial progenitor cells improves their ability to repair the infarcted myocardium. Cell Biol Int 2015;39:1251-1263.

-401 Khan I, Ali A, Akhter MA, Naeem N, Chotani MA, Iqbal H, Kabir N, Atiq M, Salim A: Epac-Rap1-activated mesenchymal stem cells improve cardiac function in rat model of myocardial infarction. Cardiovasc Ther 2017;35.

402 Han D, Li X, Fan WS, Chen JW, Gou TT, Su T, Fan MM, Xu MQ Wang YB, Ma S, Qiu Y, Cao F: Activation of cannabinoid receptor type II by AM1241 protects adipose-derived mesenchymal stem cells from oxidative damage and enhances their therapeutic efficacy in myocardial infarction mice via Stat 3 activation. Oncotarget 2017;8:64853-64866.

403 Ghiroldi A, Piccoli M, Ciconte G, Pappone C, Anastasia L: Regenerating the human heart: direct reprogramming strategies and their current limitations. Basic Res Cardiol 2017;112:68.

-404 Hausburg F, Jung JJ, Hoch M, Wolfien M, Yavari A, Rimmbach C, David R: (Re-)programming of subtype specific cardiomyocytes. Adv Drug Deliv Rev 2017;120:142-167.

405 Protze SI, Liu J, Nussinovitch U, Ohana L, Backx PH, Gepstein L, Keller GM: Sinoatrial node cardiomyocytes derived from human pluripotent cells function as a biological pacemaker. Nat Biotechnol 2017;35:56-68.

-406 Bhattacharya S, Burridge PW, Kropp EM, Chuppa SL, Kwok WM, Wu JC, Boheler KR, Gundry RL: High efficiency differentiation of human pluripotent stem cells to cardiomyocytes and characterization by flow cytometry. J Vis Exp 2014:52010.

407 Pei F, Jiang J, Bai S, Cao H, Tian L, Zhao Y, Yang C, Dong H, Ma Y: Chemical-defined and albumin-free generation of human atrial and ventricular myocytes from human pluripotent stem cells. Stem Cell Res 2017;19:94-103.

408 Kempf H, Olmer R, Haase A, Franke A, Bolesani E, Schwanke K, Robles-Diaz D, Coffee M, Göhring G, Dräger G, Pötz O, Joos T, Martinez-Hackert E, Haverich A, Buettner FFR, Martin U, Zweigerdt R: Bulk cell density and Wnt/TGFbeta signalling regulate mesendodermal patterning of human pluripotent stem cells. Nat Commun 2016;7:13602. 


\section{Cellular Physiology Cell Physiol Biochem 2018;48:2607-2655 \begin{tabular}{ll|l} 
and Biochemistry Publisned onIIne: 16 August, 2018 & $\begin{array}{l}\text { (c) } 2018 \text { The Author(s). Published by S. Karger AG, Basel } \\
\text { www.karger.com/cpb }\end{array}$ \\
\hline
\end{tabular} \\ Müller et al.: Cardiac Stem Cell Therapy}

409 Palpant NJ, Pabon L, Friedman CE, Roberts M, Hadland B, Zaunbrecher RJ, Bernstein I, Zheng Y, Murry CE: Generating high-purity cardiac and endothelial derivatives from patterned mesoderm using human pluripotent stem cells. Nat Protoc 2017;12:15-31.

410 Pasha Z, Wang Y, Sheikh R, Zhang D, Zhao T, Ashraf M: Preconditioning enhances cell survival and differentiation of stem cells during transplantation in infarcted myocardium. Cardiovasc Res 2008;77:134142.

411 Lu G, Haider HK, Jiang S, Ashraf M: Sca-1+ stem cell survival and engraftment in the infarcted heart: dual role for preconditioning-induced connexin-43. Circulation 2009;119:2587-2596.

-412 Herrmann JL, Wang Y, Abarbanell AM, Weil BR, Tan J, Meldrum DR: Preconditioning mesenchymal stem cells with transforming growth factor-alpha improves mesenchymal stem cell-mediated cardioprotection. Shock 2010;33:24-30.

413 Emmert MY, Wolint P, Jakab A, Sheehy SP, Pasqualini FS, Nguyen TDL, Hilbe M, Seifert B, Weber B, Brokopp CE, Macejovska D, Caliskan E, von Eckardstein A, Schwartlander R, Vogel V, Falk V, Parker KK, Gyöngyösi M, Hoerstrup SP: Safety and efficacy of cardiopoietic stem cells in the treatment of post-infarction leftventricular dysfunction - From cardioprotection to functional repair in a translational pig infarction model. Biomaterials 2017;122:48-62.

414 Behfar A, Yamada S, Crespo-Diaz R, Nesbitt JJ, Rowe LA, Perez-Terzic C, Gaussin V, Homsy C, Bartunek J, Terzic A: Guided cardiopoiesis enhances therapeutic benefit of bone marrow human mesenchymal stem cells in chronic myocardial infarction. J Am Coll Cardiol 2010;56:721-734.

-415 Bartunek J, Behfar A, Dolatabadi D, Vanderheyden M, Ostojic M, Dens J, El Nakadi B, Banovic M, Beleslin B, Vrolix M, Legrand V, Vrints C, Vanoverschelde JL, Crespo-Diaz R, Homsy C, Tendera M, Waldman S, Wijns W, Terzic A: Cardiopoietic stem cell therapy in heart failure: the C-CURE (Cardiopoietic stem Cell therapy in heart failURE) multicenter randomized trial with lineage-specified biologics. J Am Coll Cardiol 2013;61:2329-2338.

416 Bartunek J, Terzic A, Davison BA, Filippatos GS, Radovanovic S, Beleslin B, Merkely B, Musialek P, Wojakowski W, Andreka P, Horvath IG, Katz A, Dolatabadi D, El Nakadi B, Arandjelovic A, Edes I, Seferovic PM, Obradovic S, Vanderheyden M, Jagic N, et al.: Cardiopoietic cell therapy for advanced ischaemic heart failure: results at 39 weeks of the prospective, randomized, double blind, sham-controlled CHART-1 clinical trial. Eur Heart J 2017;38:648-660.

417 Teerlink JR, Metra M, Filippatos GS, Davison BA, Bartunek J, Terzic A, Gersh BJ, Povsic TJ, Henry TD, Alexandre B, Homsy C, Edwards C, Seron A, Wijns W, Cotter G: Benefit of cardiopoietic mesenchymal stem cell therapy on left ventricular remodelling: results from the Congestive Heart Failure Cardiopoietic Regenerative Therapy (CHART-1) study. Eur J Heart Fail 2017;19:1520-1529.

418 Dall C, Khan M, Chen CA, Angelos MG: Oxygen cycling to improve survival of stem cells for myocardial repair: A review. Life Sci 2016;153:124-131.

419 Yu SP, Wei Z, Wei L: Preconditioning strategy in stem cell transplantation therapy. Transl Stroke Res 2013;4:76-88.

420 Hosoyama T, Samura M, Kudo T, Nishimoto A, Ueno K, Murata T, Ohama T, Sato K, Mikamo A, Yoshimura K, Li TS, Hamano K: Cardiosphere-derived cell sheet primed with hypoxia improves left ventricular function of chronically infarcted heart. Am J Transl Res 2015;7:2738-2751.

421 Jaussaud J, Biais M, Calderon J, Chevaleyre J, Duchez P, Ivanovic Z, Couffinhal T, Barandon L: Hypoxiapreconditioned mesenchymal stromal cells improve cardiac function in a swine model of chronic myocardial ischaemia. Eur J Cardiothorac Surg 2013;43:1050-1057.

422 Tang YL, Zhu W, Cheng M, Chen L, Zhang J, Sun T, Kishore R, Phillips MI, Losordo DW, Qin G: Hypoxic preconditioning enhances the benefit of cardiac progenitor cell therapy for treatment of myocardial infarction by inducing CXCR4 expression. Circ Res 2009;104:1209-1216.

423 Uemura R, Xu M, Ahmad N, Ashraf M: Bone marrow stem cells prevent left ventricular remodeling of ischemic heart through paracrine signaling. Circ Res 2006;98:1414-1421.

424 He A, Jiang Y, Gui C, Sun Y, Li J, Wang JA: The antiapoptotic effect of mesenchymal stem cell transplantation on ischemic myocardium is enhanced by anoxic preconditioning. Can J Cardiol 2009;25:353-358.

425 Hu X, Yu SP, Fraser JL, Lu Z, Ogle ME, Wang JA, Wei L: Transplantation of hypoxia-preconditioned mesenchymal stem cells improves infarcted heart function via enhanced survival of implanted cells and angiogenesis. J Thorac Cardiovasc Surg 2008;135:799-808. 


\section{Cellular Physiology Cell Physiol Biochem 2018;48:2607-2655 \begin{tabular}{ll|l} 
and Biochemistry Publisnea onine: 10 August, 2018 & $\begin{array}{l}\text { (c) } 2018 \text { The Author(s). Published by S. Karger AG, Basel } \\
\text { www.karger.com/cpb }\end{array}$ \\
\hline
\end{tabular}

426 Hu X, Xu Y, Zhong Z, Wu Y, Zhao J, Wang Y, Cheng H, Kong M, Zhang F, Chen Q Sun J, Li Q Jin J, Li Q, Chen L, Wang C, Zhan H, Fan Y, Yang Q, Yu L, et al.: A Large-Scale Investigation of Hypoxia-Preconditioned Allogeneic Mesenchymal Stem Cells for Myocardial Repair in Nonhuman Primates: Paracrine Activity Without Remuscularization. Circ Res 2016;118:970-983.

427 Feng Y, Huang W, Meng W, Jegga AG, Wang Y, Cai W, Kim HW, Pasha Z, Wen Z, Rao F, Modi RM, Yu X, Ashraf M: Heat shock improves Sca-1+ stem cell survival and directs ischemic cardiomyocytes toward a prosurvival phenotype via exosomal transfer: a critical role for HSF1/miR-34a/HSP70 pathway. Stem Cells 2014;32:462-472.

428 Moloney TC, Hoban DB, Barry FP, Howard L, Dowd E: Kinetics of thermally induced heat shock protein 27 and 70 expression by bone marrow-derived mesenchymal stem cells. Protein Sci 2012;21:904-909.

429 Qiao P-F, Yao L, Zhang XC, Li GD, Wu DQ: Heat shock pretreatment improves stem cell repair following ischemia-reperfusion injury via autophagy. World J Gastroenterol 2015;21:12822-12834.

-430 Christman KL, Vardanian AJ, Fang Q Sievers RE, Fok HH, Lee RJ: Injectable fibrin scaffold improves cell transplant survival, reduces infarct expansion, and induces neovasculature formation in ischemic myocardium. J Am Coll Cardiol 2004;44:654-660.

431 Ryu JH, Kim IK, Cho SW, Cho MC, Hwang KK, Piao H, Piao S, Lim SH, Hong YS, Choi CY, Yoo KJ, Kim BS: Implantation of bone marrow mononuclear cells using injectable fibrin matrix enhances neovascularization in infarcted myocardium. Biomaterials 2005;26:319-326.

432 Zhang X, Wang H, Ma X, Adila A, Wang B, Liu F, Chen B, Wang C, Ma Y: Preservation of the cardiac function in infarcted rat hearts by the transplantation of adipose-derived stem cells with injectable fibrin scaffolds. Exp Biol Med (Maywood) 2010;235:1505-1515.

433 Kofidis T, Lebl DR, Martinez EC, Hoyt G, Tanaka M, Robbins RC: Novel injectable bioartificial tissue facilitates targeted, less invasive, large-scale tissue restoration on the beating heart after myocardial injury. Circulation 2005;112:I173-7.

434 Liu Z, Wang H, Wang Y, Lin Q, Yao A, Cao F, Li D, Zhou J, Duan C, Du Z, Wang Y, Wang C: The influence of chitosan hydrogel on stem cell engraftment, survival and homing in the ischemic myocardial microenvironment. Biomaterials 2012;33:3093-3106.

435 Li X, Zhou J, Liu Z, Chen J, Lü S, Sun H, Li J, Lin Q, Yang B, Duan C, Xing MM, Wang C: A PNIPAAm-based thermosensitive hydrogel containing SWCNTs for stem cell transplantation in myocardial repair. Biomaterials 2014;35:5679-5688.

436 Li XY, Wang T, Jiang J, Lin T, Wu D-Q, Zhang XZ, Okello E, Xu HX, Yuan MJ: Injectable hydrogel helps bone marrow-derived mononuclear cells restore infarcted myocardium. Cardiology 2010;115:194-199.

437 Rashedi I, Talele N, Wang XH, Hinz B, Radisic M, Keating A: Collagen scaffold enhances the regenerative properties of mesenchymal stromal cells. PLoS One 2017;12:e0187348.

438 Simpson DL, Dudley SC: Modulation of human mesenchymal stem cell function in a three-dimensional matrix promotes attenuation of adverse remodelling after myocardial infarction. J Tissue Eng Regen Med 2013;7:192-202.

439 Maureira P, Marie PY, Yu F, Poussier S, Liu Y, Groubatch F, Falanga A, Tran N: Repairing chronic myocardial infarction with autologous mesenchymal stem cells engineered tissue in rat promotes angiogenesis and limits ventricular remodeling. J Biomed Sci 2012;19:93.

440 Blondiaux E, Pidial L, Autret G, Rahmi G, Balvay D, Audureau E, Wilhelm C, Guerin CL, Bruneval P, Silvestre JS, Menasché P, Clément O: Bone marrow-derived mesenchymal stem cell-loaded fibrin patches act as a reservoir of paracrine factors in chronic myocardial infarction. J Tissue Eng Regen Med 2017;11:34173427.

441 Ichihara Y, Kaneko M, Yamahara K, Koulouroudias M, Sato N, Uppal R, Yamazaki K, Saito S, Suzuki K: Selfassembling peptide hydrogel enables instant epicardial coating of the heart with mesenchymal stromal cells for the treatment of heart failure. Biomaterials 2018;154:12-23.

442 Hamdi H, Planat-Benard V, Bel A, Puymirat E, Geha R, Pidial L, Nematalla H, Bellamy V, Bouaziz P, Peyrard $S$, Casteilla L, Bruneval $P$, Hagège AA, Agbulut $O$, Menasché $P$ : Epicardial adipose stem cell sheets results in greater post-infarction survival than intramyocardial injections. Cardiovasc Res 2011;91:483-491.

-443 Gaetani R, Feyen DA, Verhage V, Slaats R, Messina E, Christman KL, Giacomello A, Doevendans PA, Sluijter JP: Epicardial application of cardiac progenitor cells in a 3D-printed gelatin/hyaluronic acid patch preserves cardiac function after myocardial infarction. Biomaterials 2015;61:339-348. 


\section{Cellular Physiology Cell Physiol Biochem 2018;48:2607-2655 \begin{tabular}{ll|l} 
and Biochemistry Published onlIne: 16 August, 2018 & $\begin{array}{l}\text { (c) } 2018 \text { The Author(s). Published by S. Karger AG, Basel } \\
\text { www.karger.com/cpb }\end{array}$ \\
\hline
\end{tabular} \\ Müller et al.: Cardiac Stem Cell Therapy}

444 Madonna R, Petrov L, Teberino MA, Manzoli L, Karam JP, Renna FV, Ferdinandy P, Montero-Menei CN, YläHerttuala S, de Caterina R: Transplantation of adipose tissue mesenchymal cells conjugated with VEGFreleasing microcarriers promotes repair in murine myocardial infarction. Cardiovasc Res 2015;108:39-49.

445 Rufaihah AJ, Seliktar D: Hydrogels for therapeutic cardiovascular angiogenesis. Adv Drug Deliv Rev 2016;96:31-39.

446 French KM, Somasuntharam I, Davis ME: Self-assembling peptide-based delivery of therapeutics for myocardial infarction. Adv Drug Deliv Rev 2016;96:40-53.

447 Fakoya A0J: New Delivery Systems of Stem Cells for Vascular Regeneration in Ischemia. Front Cardiovasc Med 2017;4:7.

448 Holladay CA, Duffy AM, Chen X, Sefton MV, O’Brien TD, Pandit AS: Recovery of cardiac function mediated by MSC and interleukin-10 plasmid functionalised scaffold. Biomaterials 2012;33:1303-1314.

449 Hirt MN, Hansen A, Eschenhagen T: Cardiac tissue engineering: state of the art. Circ Res 2014;114:354-367.

450 Devarasetty M, Mazzocchi AR, Skardal A: Applications of Bioengineered 3D Tissue and Tumor Organoids in Drug Development and Precision Medicine: Current and Future. BioDrugs 2018;32:53-68.

451 Smith AST, Macadangdang J, Leung W, Laflamme MA, Kim DH: Human iPSC-derived cardiomyocytes and tissue engineering strategies for disease modeling and drug screening. Biotechnol Adv 2017;35:77-94.

452 Breckwoldt K, Letuffe-Brenière D, Mannhardt I, Schulze T, Ulmer B, Werner T, Benzin A, Klampe B, Reinsch MC, Laufer S, Shibamiya A, Prondzynski M, Mearini G, Schade D, Fuchs S, Neuber C, Krämer E, Saleem U, Schulze ML, Rodriguez ML, et al.: Differentiation of cardiomyocytes and generation of human engineered heart tissue. Nat Protoc 2017;12:1177-1197.

453 Nakane T, Masumoto H, Tinney JP, Yuan F, Kowalski WJ, Ye F, LeBlanc AJ, Sakata R, Yamashita JK, Keller BB: Impact of Cell Composition and Geometry on Human Induced Pluripotent Stem Cells-Derived Engineered Cardiac Tissue. Sci Rep 2017;7:45641.

\$454 Giacomelli E, Bellin M, Sala L, van Meer BJ, Tertoolen LGJ, Orlova VV, Mummery CL: Three-dimensional cardiac microtissues composed of cardiomyocytes and endothelial cells co-differentiated from human pluripotent stem cells. Development 2017;144:1008-1017.

-455 Gao L, Kupfer ME, Jung JP, Yang L, Zhang P, Da Sie Y, Tran Q, Ajeti V, Freeman BT, Fast VG, Campagnola PJ, Ogle BM, Zhang J: Myocardial Tissue Engineering With Cells Derived From Human-Induced Pluripotent Stem Cells and a Native-Like, High-Resolution, 3-Dimensionally Printed Scaffold. Circ Res 2017;120:13181325.

456 Taylor DA, Parikh RB, Sampaio LC: Bioengineering Hearts: Simple yet Complex. Curr Stem Cell Rep 2017;3:35-44.

457 Conant G, Lai BFL, Lu RXZ, Korolj A, Wang EY, Radisic M: High-Content Assessment of Cardiac Function Using Heart-on-a-Chip Devices as Drug Screening Model. Stem Cell Rev 2017;13:335-346.

458 Li RA, Keung W, Cashman TJ, Backeris PC, Johnson BV, Bardot ES, Wong AOT, Chan PKW, Chan CWY, Costa KD: Bioengineering an electro-mechanically functional miniature ventricular heart chamber from human pluripotent stem cells. Biomaterials 2018;163:116-127.

459 Liu J, Narsinh KH, Lan F, Wang L, Nguyen PK, Hu S, Lee A, Han L, Gong Y, Huang M, Nag D, Rosenberg J, Chouldechova A, Robbins RC, Wu JC: Early stem cell engraftment predicts late cardiac functional recovery: preclinical insights from molecular imaging. Circ Cardiovasc Imaging 2012;5:481-490.

\$60 Lang C, Lehner S, Todica A, Boening G, Zacherl M, Franz WM, Krause BJ, Bartenstein P, Hacker M, David R: In-vivo comparison of the acute retention of stem cell derivatives and fibroblasts after intramyocardial transplantation in the mouse model. Eur J Nucl Med Mol Imaging 2014;41:2325-2336.

461 Lang C, Lehner S, Todica A, Boening G, Franz WM, Bartenstein P, Hacker M, David R: Positron emission tomography based in-vivo imaging of early phase stem cell retention after intramyocardial delivery in the mouse model. Eur J Nucl Med Mol Imaging 2013;40:1730-1738.

462 Kang WJ, Kang HJ, Kim HS, Chung JK, Lee MC, Lee DS: Tissue distribution of 18F-FDG-labeled peripheral hematopoietic stem cells after intracoronary administration in patients with myocardial infarction. J Nucl Med 2006;47:1295-1301.

-463 Goussetis E, Manginas A, Koutelou M, Peristeri I, Theodosaki M, Kollaros N, Leontiadis E, Theodorakos A, Paterakis G, Karatasakis G, Cokkinos DV, Graphakos S: Intracoronary infusion of CD133+ and CD133-CD34+ selected autologous bone marrow progenitor cells in patients with chronic ischemic cardiomyopathy: cell isolation, adherence to the infarcted area, and body distribution. Stem Cells 2006;24:2279-2283. 


\section{Cellular Physiology Cell Physiol Biochem 2018;48:2607-2655 \begin{tabular}{ll|l} 
and Biochemistry Publisned onIIne: 16 August, 2018 & $\begin{array}{l}\text { (c) } 2018 \text { The Author(s). Published by S. Karger AG, Basel } \\
\text { www.karger.com/cpb }\end{array}$ \\
\hline
\end{tabular}

464 Musialek P, Tekieli L, Kostkiewicz M, Miszalski-Jamka T, Klimeczek P, Mazur W, Szot W, Majka M, Banys RP, Jarocha D, Walter Z, Krupinski M, Pieniazek P, Olszowska M, Zmudka K, Pasowicz M, Kereiakes DJ, Tracz W, Podolec P, Wojakowski W: Infarct size determines myocardial uptake of CD34+ cells in the peri-infarct zone: Results from a study of $(99 \mathrm{~m}) \mathrm{Tc}$-extametazime-labeled cell visualization integrated with cardiac magnetic resonance infarct imaging. Circ Cardiovasc Imaging 2013;6:320-328.

465 Silva LHA, Cruz FF, Morales MM, Weiss DJ, Rocco PRM: Magnetic targeting as a strategy to enhance therapeutic effects of mesenchymal stromal cells. Stem Cell Res Ther 2017;8:58.

466 Vandergriff AC, Hensley TM, Henry ET, Shen D, Anthony S, Zhang J, Cheng K: Magnetic targeting of cardiosphere-derived stem cells with ferumoxytol nanoparticles for treating rats with myocardial infarction. Biomaterials 2014;35:8528-8539.

467 Huang Z, Shen Y, Sun A, Huang G, Zhu H, Huang B, Xu J, Song Y, Pei N, Ma J, Yang X, Zou Y, Qian J, Ge J: Magnetic targeting enhances retrograde cell retention in a rat model of myocardial infarction. Stem Cell Res Ther 2013;4:149.

468 Müller P, Voronina N, Hausburg F, Lux CA, Wiekhorst F, Steinhoff G, David R: Magnet-Bead Based MicroRNA Delivery System to Modify CD133+ Stem Cells. Stem Cells Int 2016;2016:7152761.

469 Schade A, Müller P, Delyagina E, Voronina N, Skorska A, Lux C, Steinhoff G, David R: Magnetic Nanoparticle Based Nonviral MicroRNA Delivery into Freshly Isolated CD105(+) hMSCs. Stem Cells Int 2014;2014:197154.

470 Cheng K, Malliaras K, Li TS, Sun B, Houde C, Galang G, Smith J, Matsushita N, Marbán E: Magnetic enhancement of cell retention, engraftment, and functional benefit after intracoronary delivery of cardiacderived stem cells in a rat model of ischemia/reperfusion. Cell Transplant 2012;21:1121-1135.

-471 Tran LA, Hernández-Rivera M, Berlin AN, Zheng Y, Sampaio L, Bové C, Cabreira-Hansen MdG, Willerson JT, Perin EC, Wilson LJ: The use of gadolinium-carbon nanostructures to magnetically enhance stem cell retention for cellular cardiomyoplasty. Biomaterials 2014;35:720-726.

-472 Rojas SV, Meier M, Zweigerdt R, Eckardt D, Rathert C, Schecker N, Schmitto JD, Rojas-Hernandez S, Martin U, Kutschka I, Haverich A, Martens A: Multimodal Imaging for In Vivo Evaluation of Induced Pluripotent Stem Cells in a Murine Model of Heart Failure. Artif Organs 2017;41:192-199.

-473 Voronina N, Lemcke H, Wiekhorst F, Kühn JP, Rimmbach C, Steinhoff G, David R: Non-viral magnetic engineering of endothelial cells with microRNA and plasmid-DNA-An optimized targeting approach. Nanomedicine 2016;12:2353-2364.

474 Naumova AV, Balu N, Yarnykh VL, Reinecke H, Murry CE, Yuan C: Magnetic Resonance Imaging Tracking of Graft Survival in the Infarcted Heart: Iron Oxide Particles Versus Ferritin Overexpression Approach. J Cardiovasc Pharmacol Ther 2014;19:358-367.

475 Hua P, Wang YY, Liu LB, Liu JL, Liu JY, Yang YQ, Yang SR: In vivo magnetic resonance imaging tracking of transplanted superparamagnetic iron oxide-labeled bone marrow mesenchymal stem cells in rats with myocardial infarction. Mol Med Rep 2015;11:113-120.

476 Terrovitis J, Stuber M, Youssef A, Preece S, Leppo M, Kizana E, Schär M, Gerstenblith G, Weiss RG, Marbán E, Abraham MR: Magnetic resonance imaging overestimates ferumoxide-labeled stem cell survival after transplantation in the heart. Circulation 2008;117:1555-1562.

477 Huang Z, Li C, Yang S, Xu J, Shen Y, Xie X, Dai Y, Lu H, Gong H, Sun A, Qian J, Ge J: Magnetic resonance hypointensive signal primarily originates from extracellular iron particles in the long-term tracking of mesenchymal stem cells transplanted in the infarcted myocardium. Int J Nanomedicine 2015;10:16791690.

478 Woudstra L, Krijnen PA, Bogaards SJ, Meinster E, Emmens RW, Kokhuis TJ, Bollen IA, Baltzer H, Baart SM, Parbhudayal R, Helder MN, van Hinsbergh VW, Musters RJ, de Jong N, Kamp O, Niessen HW, van Dijk A, Juffermans LJ: Development of a new therapeutic technique to direct stem cells to the infarcted heart using targeted microbubbles: StemBells. Stem Cell Res 2016;17:6-15.

479 Tang J, Shen D, Caranasos TG, Wang Z, Vandergriff AC, Allen TA, Hensley MT, Dinh PU, Cores J, Li TS, Zhang J, Kan Q, Cheng K: Therapeutic microparticles functionalized with biomimetic cardiac stem cell membranes and secretome. Nat Commun 2017;8:13724.

480 Luo L, Tang J, Nishi K, Yan C, Dinh PU, Cores J, Kudo T, Zhang J, Li T, Cheng K: Fabrication of Synthetic Mesenchymal Stem Cells for the Treatment of Acute Myocardial Infarction in Mice. Circ Res 2017;120:1768-1775. 


\section{Cellular Physiology Cell Physiol Biochem 2018;48:2607-2655 \begin{tabular}{ll|l} 
DOI: 10.1159/000492704 & $\begin{array}{l}\text { O 2018 The Author(s). Published by S. Karger AG, Basel } \\
\text { www.karger.com/cpb }\end{array}$
\end{tabular}

481 Cornu TI, Mussolino C, Cathomen T: Refining strategies to translate genome editing to the clinic. Nat Med 2017;23:415-423.

482 Tam C, Wong JH, Cheung RCF, Zuo T, Ng TB: Therapeutic potentials of short interfering RNAs. Appl Microbiol Biotechnol 2017;101:7091-7111.

483 Lemcke H, Voronina N, Steinhoff G, David R: Recent Progress in Stem Cell Modification for Cardiac Regeneration. Stem Cells Int 2018;2018:1-22.

484 Lam JK, Chow MYT, Zhang Y, Leung SW: siRNA Versus miRNA as Therapeutics for Gene Silencing. Mol Ther Nucleic Acids 2015;4:e252.

-485 Karpov AA, Udalova DV, Pliss MG, Galagudza MM: Can the outcomes of mesenchymal stem cell-based therapy for myocardial infarction be improved? Providing weapons and armour to cells. Cell Prolif 2017;50.

-486 Tilokee EL, Latham N, Jackson R, Mayfield AE, Ye B, Mount S, Lam BK, Suuronen EJ, Ruel M, Stewart DJ, Davis DR: Paracrine Engineering of Human Explant-Derived Cardiac Stem Cells to Over-Express StromalCell Derived Factor $1 \alpha$ Enhances Myocardial Repair. Stem Cells 2016;34:1826-1835.

487 Jackson R, Tilokee EL, Latham N, Mount S, Rafatian G, Strydhorst J, Ye B, Boodhwani M, Chan V, Ruel M, Ruddy TD, Suuronen EJ, Stewart DJ, Davis DR: Paracrine Engineering of Human Cardiac Stem Cells With Insulin-Like Growth Factor 1 Enhances Myocardial Repair. J Am Heart Assoc 2015;4:e002104.

488 Bagno LL, Carvalho D, Mesquita F, Louzada RA, Andrade B, Kasai-Brunswick TH, Lago VM, Suhet G, Cipitelli D, Werneck-de-Castro JP, Campos-de-Carvalho AC: Sustained IGF-1 Secretion by Adipose-Derived Stem Cells Improves Infarcted Heart Function. Cell Transplant 2016;25:1609-1622.

489 Zhao L, Liu X, Zhang Y, Liang X, Ding Y, Xu Y, Fang Z, Zhang F: Enhanced cell survival and paracrine effects of mesenchymal stem cells overexpressing hepatocyte growth factor promote cardioprotection in myocardial infarction. Exp Cell Res 2016;344:30-39.

490 Wu Z, Chen G, Zhang J, Hua Y, Li J, Liu B, Huang A, Li H, Chen M, Ou C: Treatment of Myocardial Infarction with Gene-modified Mesenchymal Stem Cells in a Small Molecular Hydrogel. Sci Rep 2017;7:15826.

491 Xue X, Liu Y, Zhang J, Liu T, Yang Z, Wang H: Bcl-xL Genetic Modification Enhanced the Therapeutic Efficacy of Mesenchymal Stem Cell Transplantation in the Treatment of Heart Infarction. Stem Cells Int 2015;2015:176409.

492 Li W, Ma N, Ong LL, Nesselmann C, Klopsch C, Ladilov Y, Furlani D, Piechaczek C, Moebius JM, Lützow K, Lendlein A, Stamm C, Li RK, Steinhoff G: Bcl-2 engineered MSCs inhibited apoptosis and improved heart function. Stem Cells 2007;25:2118-2127.

493 Mao Q Lin C, Gao J, Liang X, Gao W, Shen L, Kang L, Xu B: Mesenchymal stem cells overexpressing integrinlinked kinase attenuate left ventricular remodeling and improve cardiac function after myocardial infarction. Mol Cell Biochem 2014;397:203-214.

494 Song SW, Chang W, Song BW, Song H, Lim S, Kim HJ, Cha MJ, Choi E, Im SH, Chang BC, Chung N, Jang Y, Hwang KC: Integrin-linked kinase is required in hypoxic mesenchymal stem cells for strengthening cell adhesion to ischemic myocardium. Stem Cells 2009;27:1358-1365.

495 Noiseux N, Gnecchi M, Lopez-Ilasaca M, Zhang L, Solomon SD, Deb A, Dzau VJ, Pratt RE: Mesenchymal stem cells overexpressing Akt dramatically repair infarcted myocardium and improve cardiac function despite infrequent cellular fusion or differentiation. Mol Ther 2006;14:840-850.

496 Lim SY, Kim YS, Ahn Y, Jeong MH, Hong MH, Joo SY, Nam KI, Cho JG, Kang PM, Park JC: The effects of mesenchymal stem cells transduced with Akt in a porcine myocardial infarction model. Cardiovasc Res 2006;70:530-542.

497 Gnecchi M, He H, Noiseux N, Liang OD, Zhang L, Morello F, Mu H, Melo LG, Pratt RE, Ingwall JS, Dzau VJ: Evidence supporting paracrine hypothesis for Akt-modified mesenchymal stem cell-mediated cardiac protection and functional improvement. FASEB J 2006;20:661-669.

498 Jiang S, Haider HK, Idris NM, Salim A, Ashraf M: Supportive interaction between cell survival signaling and angiocompetent factors enhances donor cell survival and promotes angiomyogenesis for cardiac repair. Circ Res 2006;99:776-784.

499 Li L, Guan Q Dai S, Wei W, Zhang Y: Integrin $\beta 1$ Increases Stem Cell Survival and Cardiac Function after Myocardial Infarction. Front Pharmacol 2017;8:135.

500 Beavers KR, Nelson CE, Duvall CL: MiRNA inhibition in tissue engineering and regenerative medicine. Adv Drug Deliv Rev 2015;88:123-137. 


\section{Cellular Physiology Cell Physiol Biochem 2018;48:2607-2655 \begin{tabular}{ll|l} 
and Biochemistry Publisned onIIne: 16 August, 2018 & $\begin{array}{l}\text { (c) } 2018 \text { The Author(s). Published by S. Karger AG, Basel } \\
\text { www.karger.com/cpb }\end{array}$ \\
\hline
\end{tabular} \\ Müller et al.: Cardiac Stem Cell Therapy}

501 Seo HH, Lee SY, Lee CY, Kim R, Kim P, Oh S, Lee H, Lee MY, Kim J, Kim LK, Hwang KC, Chang W: Exogenous miRNA-146a Enhances the Therapeutic Efficacy of Human Mesenchymal Stem Cells by Increasing Vascular Endothelial Growth Factor Secretion in the Ischemia/Reperfusion-Injured Heart. J Vasc Res 2017;54:100108.

502 Huang F, Zhu X, Hu XQ, Fang ZF, Tang L, Lu XL, Zhou S-: Mesenchymal stem cells modified with miR-126 release angiogenic factors and activate Notch ligand Delta-like-4, enhancing ischemic angiogenesis and cell survival. Int J Mol Med 2013;31:484-492.

-503 Joladarashi D, Garikipati VN, Thandavarayan RA, Verma SK, Mackie AR, Khan M, Gumpert AM, Bhimaraj A, Youker KA, Uribe C, Suresh Babu S, Jeyabal P, Kishore R, Krishnamurthy P: Enhanced Cardiac Regenerative Ability of Stem Cells After Ischemia-Reperfusion Injury: Role of Human CD34+ Cells Deficient in MicroRNA-377. J Am Coll Cardiol 2015;66:2214-2226.

504 Wen Z, Huang W, Feng Y, Cai W, Wang Y, Wang X, Liang J, Wani M, Chen J, Zhu P, Chen JM, Millard RW, Fan GC, Wang Y: MicroRNA-377 regulates mesenchymal stem cell-induced angiogenesis in ischemic hearts by targeting VEGF. PLoS One 2014;9:e104666.

505 Jakob P, Landmesser U: Role of microRNAs in stem/progenitor cells and cardiovascular repair. Cardiovasc Res 2012;93:614-622.

506 Hu S, Huang M, Nguyen PK, Gong Y, Li Z, Jia F, Lan F, Liu J, Nag D, Robbins RC, Wu JC: Novel microRNA prosurvival cocktail for improving engraftment and function of cardiac progenitor cell transplantation. Circulation 2011;124:S27-34.

507 Sen CK: MicroRNAs as new maestro conducting the expanding symphony orchestra of regenerative and reparative medicine. Physiol Genomics 2011;43:517-520.

508 Zhao XL, Yang B, Ma LN, Dong YH: MicroRNA-1 effectively induces differentiation of myocardial cells from mouse bone marrow mesenchymal stem cells. Artif Cells Nanomed Biotechnol 2016;44:1665-1670.

509 Shen X, Pan B, Zhou H, Liu L, Lv T, Zhu J, Huang X, Tian J: Differentiation of mesenchymal stem cells into cardiomyocytes is regulated by miRNA-1-2 via WNT signaling pathway. J Biomed Sci 2017;24:29.

510 Zhang LL, Liu JJ, Liu F, Liu WHh, Wang YS, Zhu B, Yu B: MiR-499 induces cardiac differentiation of rat mesenchymal stem cells through wnt/ $\beta$-catenin signaling pathway. Biochem Biophys Res Commun 2012;420:875-881.

511 Lee SY, Ham O, Cha M, Song B-W, Choi E, Kim I, Chang W, Lim S, Lee CY, Park J-H, Lee J, Bae Y, Seo HH, Choi E, Jang Y, Hwang KC: The promotion of cardiogenic differentiation of hMSCs by targeting epidermal growth factor receptor using microRNA-133a. Biomaterials 2013;34:92-99.

512 Hosoda T, Zheng H, Cabral-da-Silva M, Sanada F, Ide-Iwata N, Ogórek B, Ferreira-Martins J, Arranto C, D’Amario D, Del Monte F, Urbanek K, D’Alessandro DA, Michler RE, Anversa P, Rota M, Kajstura J, Leri A: Human cardiac stem cell differentiation is regulated by a mircrine mechanism. Circulation 2011;123:12871296.

513 Sluijter JP, van Mil A, van Vliet P, Metz CH, Liu J, Doevendans PA, Goumans MJ: MicroRNA-1 and -499 regulate differentiation and proliferation in human-derived cardiomyocyte progenitor cells. Arterioscler Thromb Vasc Biol 2010;30:859-868.

514 Izarra A, Moscoso I, Cañón S, Carreiro C, Fondevila D, Martín-Caballero J, Blanca V, Valiente I, Díez-Juan A, Bernad A: miRNA-1 and miRNA-133a are involved in early commitment of pluripotent stem cells and demonstrate antagonistic roles in the regulation of cardiac differentiation. J Tissue Eng Regen Med 2017;11:787-799.

515 Kuppusamy KT, Jones DC, Sperber H, Madan A, Fischer KA, Rodriguez ML, Pabon L, Zhu WZ, Tulloch NL, Yang X, Sniadecki NJ, Laflamme MA, Ruzzo WL, Murry CE, Ruohola-Baker H: Let-7 family of microRNA is required for maturation and adult-like metabolism in stem cell-derived cardiomyocytes. Proc Natl Acad Sci U S A 2015;112:E2785-2794.

516 Wilson KD, Hu S, Venkatasubrahmanyam S, Fu JD, Sun N, Abilez OJ, Baugh JJ, Jia F, Ghosh Z, Li RA, Butte AJ, Wu JC: Dynamic microRNA expression programs during cardiac differentiation of human embryonic stem cells: role for miR-499. Circ Cardiovasc Genet 2010;3:426-435.

517 Favalli V, Serio A, Giuliani LP, Arbustini E: 'Precision and personalized medicine', a dream that comes true? J Cardiovasc Med (Hagerstown) 2017;18:e1-e6.

518 Alyass A, Turcotte M, Meyre D: From big data analysis to personalized medicine for all: challenges and opportunities. BMC Med Genomics 2015;8:33. 


\section{Cellular Physiology Cell Physiol Biochem 2018;48:2607-2655 \begin{tabular}{l|l|l} 
DOI: 10.1159/000492704 & $\begin{array}{l}\text { O 2018 The Author(s). Published by S. Karger AG, Basel } \\
\text { www.karger.com/cpb }\end{array}$
\end{tabular} \\ Müller et al.: Cardiac Stem Cell Therapy}

519 Dimmeler S, Leri A: Aging and disease as modifiers of efficacy of cell therapy. Circ Res 2008;102:13191330.

520 Zwetsloot PP, Gremmels H, Assmus B, Koudstaal S, Sluijter JP, Zeiher AM, Chamuleau SA: Responder Definition in Clinical Stem Cell Trials in Cardiology: Will the Real Responder Please Stand Up? Circ Res 2016;119:514-518.

-521 Jokerst JV, Cauwenberghs N, Kuznetsova T, Haddad F, Sweeney T, Hou J, Rosenberg-Hasson Y, Zhao E, Schutt R, Bolli R, Traverse JH, Pepine CJ, Henry TD, Schulman IH, Moyé L, Taylor DA, Yang PC: Circulating Biomarkers to Identify Responders in Cardiac Cell therapy. Sci Rep 2017;7:4419.

\$522 Luu B, Leistner DM, Herrmann E, Seeger FH, Honold J, Fichtlscherer S, Zeiher AM, Assmus B: Minute Myocardial Injury as Measured by High-Sensitive Troponin T Serum Levels Predicts the Response to Intracoronary Infusion of Bone Marrow-Derived Mononuclear Cells in Patients With Stable Chronic PostInfarction Heart Failure: Insights From the TOPCARE-CHD Registry. Circ Res 2017;120:1938-1946.

523 Wolfien M, Rimmbach C, Schmitz U, Jung JJ, Krebs S, Steinhoff G, David R, Wolkenhauer O: TRAPLINE: a standardized and automated pipeline for RNA sequencing data analysis, evaluation and annotation. BMC Bioinformatics 2016;17:21.

524 Steinhoff G, Nesteruk J, Wolfien M, Große J, Ruch U, Vasudevan P, Müller P: Stem cells and heart disease Brake or accelerator? Adv Drug Deliv Rev 2017;120:2-24.

525 Becher UM, Tiyerili V, Skowasch D, Nickenig G, Werner N: Personalized cardiac regeneration by stem cellsHype or hope? EPMA J 2011;2:119-130.

526 Fernández-Avilés F, Sanz-Ruiz R, Climent AM, Badimon L, Bolli R, Charron D, Fuster V, Janssens S, Kastrup J, Kim HS, Lüscher TF, Martin JF, Menasché P, Simari RD, Stone GW, Terzic A, Willerson JT, Wu JC, the TACTICS (Transnational Alliance for Regenerative Therapies in Cardiovascular Syndromes) Writing Group: Global position paper on cardiovascular regenerative medicine. Eur Heart J 2017;38:2532-2546.

527 Madonna R, van Laake LW, Davidson SM, Engel FB, Hausenloy DJ, Lecour S, Leor J, Perrino C, Schulz R, Ytrehus K, Landmesser U, Mummery CL, Janssens S, Willerson J, Eschenhagen T, Ferdinandy P, Sluijter JP: Position Paper of the European Society of Cardiology Working Group Cellular Biology of the Heart: cellbased therapies for myocardial repair and regeneration in ischemic heart disease and heart failure. Eur Heart J 2016;37:1789-1798.

528 Trindade F, Leite-Moreira A, Ferreira-Martins J, Ferreira R, Falcao-Pires I, Vitorino R: Towards the standardization of stem cell therapy studies for ischemic heart diseases: Bridging the gap between animal models and the clinical setting. Int J Cardiol 2017;228:465-480.

529 Jansen of Lorkeers SJ, Doevendans PA, Chamuleau SA: All preclinical trials should be registered in advance in an online registry. Eur J Clin Invest 2014;44:891-892. 